C $55.2: F 53 / 4$

\title{
Fish Kills in Coastal Waters 1980-1989
}

PENNSYLVANIA STATE UNIVERSITY

DEC 301991

DOCUMENTS COLLECTION U.S. Depository Copy

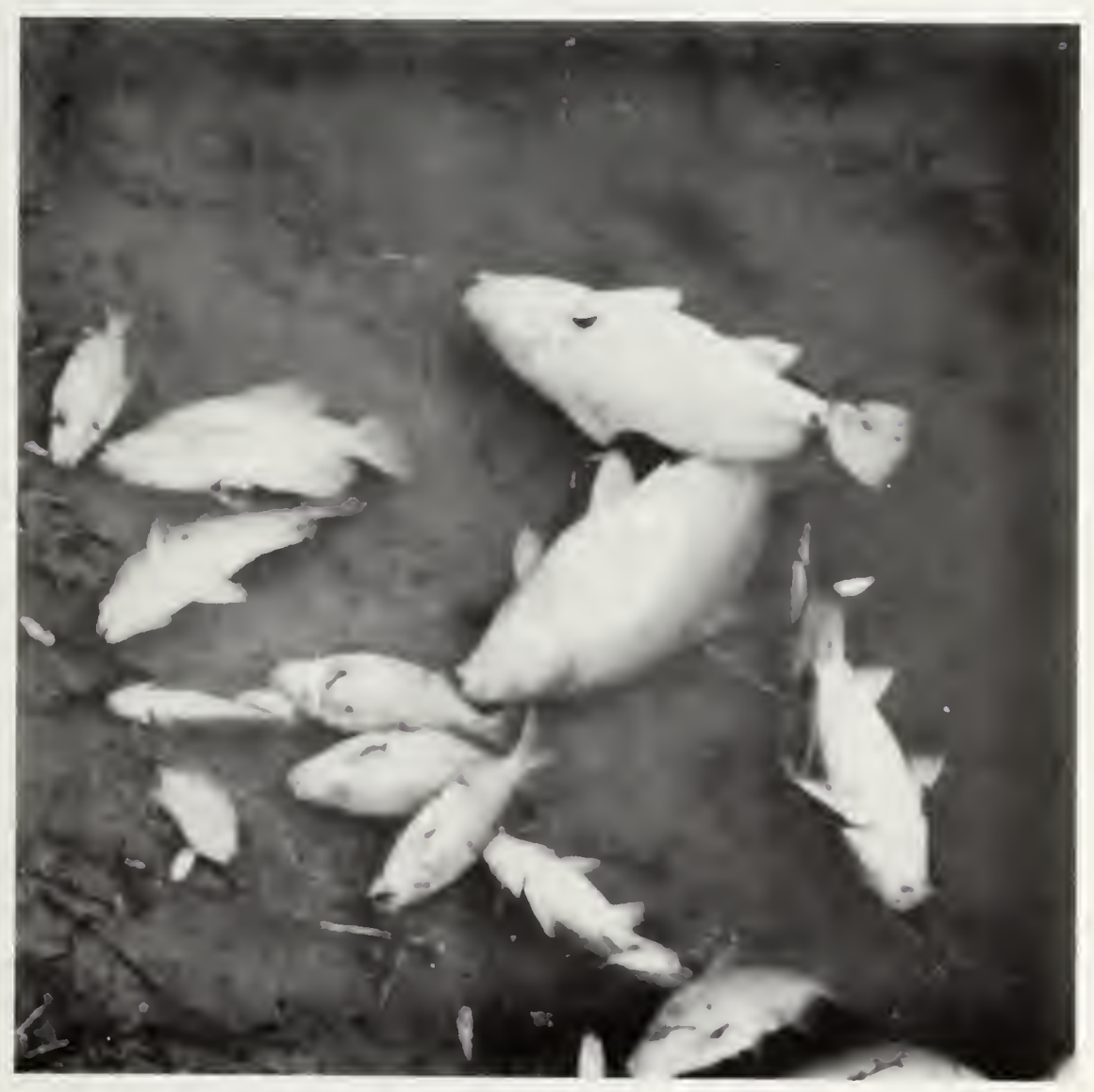

U.S. Department of Commerce

National Oceanic and Atmospheric Administration 
Cover Photo

Oyster Creek, Texas Fish Kill

by George Guillen

Texas Water Commission 


\section{Fish Kills in Coastal Waters 1980-1989}

Jamison Anne Lowe, Daniel R.G. Farrow, Anthony S. Pait, Sheila J. Arenstam, and Eileen F. Lavan

September 1991

Strategic Environmental Assessments Division Office of Ocean Resources Conservation and Assessment National Ocean Service National Oceanic and Atmospheric Administration

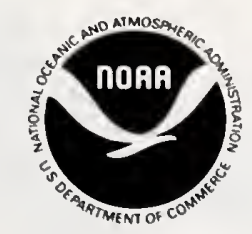




\title{
Acknowledgements
}

This report is the result of the contributions of many individuals in NOAA's Strategic Environmental Assessments Division. Daniel J. Basta provided guidance on the content and design of the report, as well as the overall layout. Davida G. Remer provided editorial guidance for graphics and tables. Kim KeeterScott served as the editor, conducted quality-control reviews of all final data tables, and coordinated printing. The project team prepared the original drafts and conducted qualitycontrol reviews of all final narrative and data in the report. In addition to the report team, Timothy Manuelides provided support in preparing graphics. Reviews of draft materials were provided by Charles N. Ehler, Louis W. Butler, Thomas J. Culliton, and Paul Paris, all of NOAA.

Special appreciation is extended to the State environmental management, fish and wildlife, and water quality enforcement officials who provided their time and data throughout the project. In addition, Nina Harllee of the U.S. Environmental Protection Agency was particularly helpful in locating state fish-kill program offices and providing fish-kill data from EPA's data base and hard copy files.

Comments on this report or questions about current and future estuarine activities should be addressed to :

\author{
Strategic Environmental \\ Assessments Division, \\ Office of Ocean Resources \\ Conservation and Assessment, \\ National Ocean Service, \\ National Oceanic and Atmospheric \\ Administration \\ 6001 Executive Blvd. \\ Rockville, Maryland 20852
}




\section{Introduction}

\section{Although fish-kill reporting programs around the Nation vary greatly, they indicate that fish kills have not been a pervasive problem in the Nation's estuarine and coastal areas. However, recurring kills or "hotspots" do occur in some areas.}

This report summarizes results of efforts across the Nation to identify, report, and assess the causes of fish kills in coastal rivers, streams, and estuarine waters between 1980 and 1989 . The location, extent, severity, timing, and cause of over 3,600 fish-kill events are documented. Data are shown for the 22 states bordering the Atlantic, Gulf of Mexico, and Pacific coasts (Figure 1).

It would be ideal if information was available on the effects of pollutants on all aquatic organisms. However, this is not the case and very little is known about how the variety of pollutants released to the environment affects these organisms. One approach to understanding these effects is to compile information on fish kills.

Although assessments based solely on fish kills provide only partial and conservative inferences of pollutant effects, they can provide useful information on the spatial and temporal dimensions of potential problems. For example, the information compiled in this report contains data on the date, location, and probable cause of kills. Analyzed together, these factors can help identify areas where recurring problems exist.

The data also provide a temporal record that can be used to help evaluate evidence of trends in water quality. Fish-kill events can be related to specific human activities such as an accidental pesticide spill or the discharge of high levels of chlorine disinfectant from a wastewater treatment plant. Events are also linked to natural phenomena such as oxygen depletion resulting from sustained periods of hot weather, coupled with low-flow conditions: or in many cases, to a more complex combination of humanrelated and natural factors such as oxygen depletion resulting from algal blooms stimulated by nutrients carried in nonpoint source runoff.

The information compiled should be useful to environmental managers and planners at the Federal, State, and local level to pinpoint "problem" areas. Compiling this information into a consistent national framework provides decisionmakers concerned with regional or national issues with the ability to target areas of concern or devise a more uniform approach to data collection.

These data are being used in two on-going projects in the National Oceanic and Atmospheric Administration's (NOAA) Strategic Environmental Assessments (SEA) Division. First, fishkill information will be used to evaluate the effects of agricultural pesticide use in coastal

Figure 1. Fish-Kill Events Reported in 22 Coastal States, 1980-1989
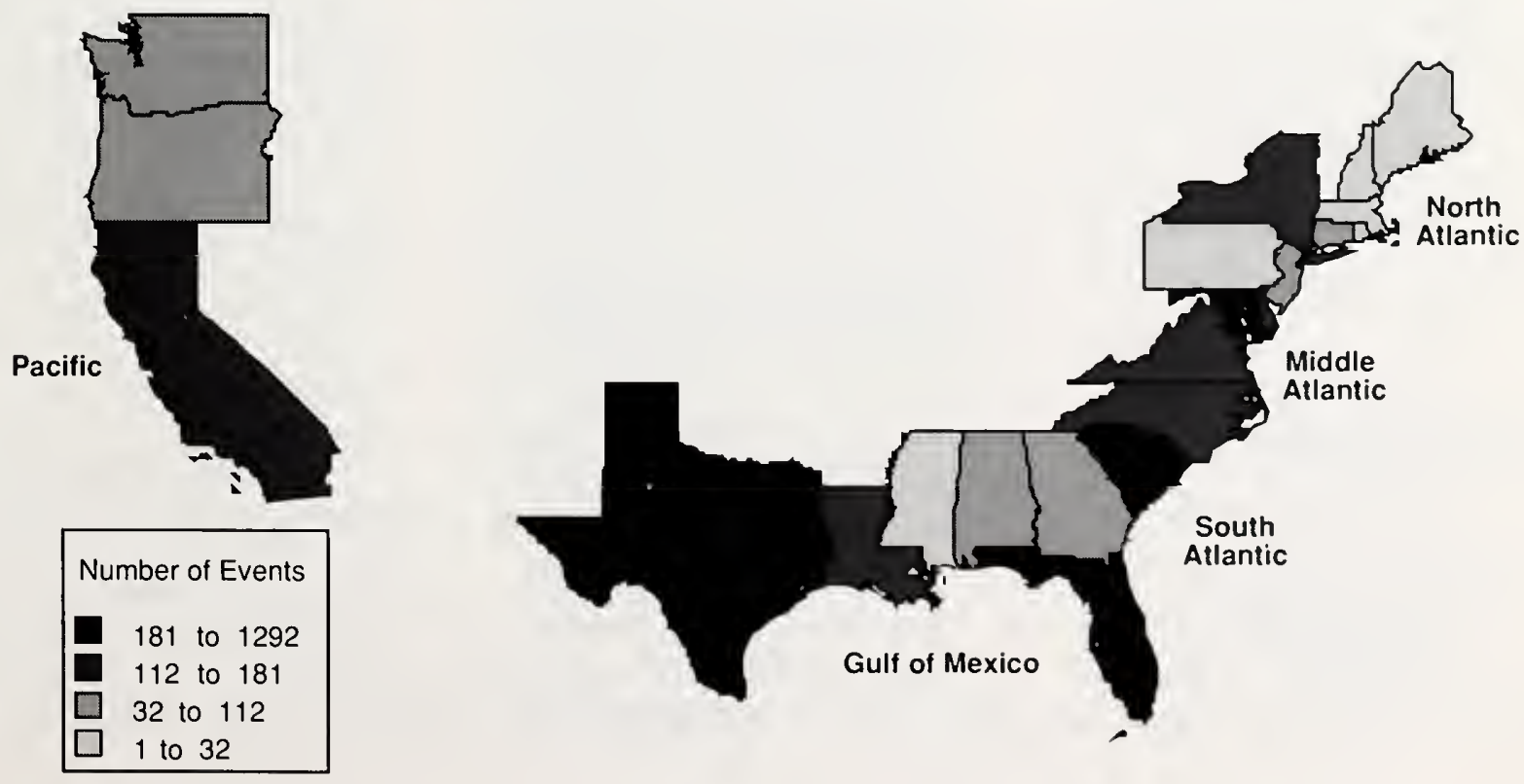
areas (Pait et al., 1991). Second, they will be used to assess nutrient enrichment problems in the Nation's estuaries through NOAA's National Estuarine Eutrophication Survey (Hinga et al., 1991).

\section{State Programs}

State agencies investigate and document fish-kill events because they typically signal a severe environmental stress on a waterbody. Each agency's immediate goal is to identify and correct the cause of the problem. Events are documented so that a record of the magnitude and probable cause exists in case an attempt is made to recover costs for the resource injury.

\section{Eighteen of 22 coastal states} indicated that responding to an environmental emergency was the primary purpose of their fish- kill reporting program(s). However, only 11 states indicated that fish-kill events are used as an environmental indicator in their water-quality assessments or in Federal assessments such as the biennial reports required by section 305(b) of the Clean Water Act (Environmental Law Institute, 1988) (Appendix B).

\section{EPA Fish-Kill Data Base}

The U.S. Environmental Protection Agency (EPA) fish-kill reporting program is a continuation of the U.S. Public Health Service program that tracked events from 1960 to 1971 . It is the only program that (until recently) has collected information nationwide on fish-kill events. Although EPA has not published a report since 1976, it continued to collect information on fish kills until recently. EPA encourages states to continue to collect data on fish kills for inclusion in the 305(b) waterquality assessment reports.

In January 1991, EPA discontinued its fish-kill reporting program due to competing program priorities.

State participation in the program was voluntary and has declined significantly since 1979. In 1988 , only 12 of 22 coastal states reported fish kills to EPA. Agencies in several states appeared to have been unaware of EPA's program. In addition, the data collected only included pollution-related fish kills and not those attributed to natural phenomena. Consequently, a significant cause of fish kills (natural phenomena) is not accounted for in the EPA data base. The EPA data base was only of limited use for this report (about a third of the information presented is from the EPA data base).

Table 1. Summary of Reported Fish-Kill Events in Coastal States, 1980-1989

\begin{tabular}{|c|c|c|c|c|c|c|c|c|c|c|}
\hline Item & 1980 & 1981 & 1982 & 1983 & 1984 & 1985 & 1986 & 1987 & 1988 & 1989 \\
\hline Number of states reporting & 21 & 21 & 16 & 15 & 17 & 18 & 20 & 20 & 19 & 18 \\
\hline Number of events & 279 & 358 & 283 & 283 & 263 & 340 & 519 & 424 & 464 & 442 \\
\hline \multicolumn{11}{|l|}{ Events that reported number } \\
\hline of fish killed & 243 & 308 & 226 & 252 & 222 & 303 & 453 & 331 & 375 & 368 \\
\hline \multicolumn{11}{|l|}{ Total estimated number } \\
\hline of fish killed (millions) & 138 & 97 & 12 & 22 & 41 & 33 & 24 & 4 & 32 & 6 \\
\hline Average size of kill (thousands) & 567 & 316 & 51 & 86 & 184 & 108 & 52 & 12 & 85 & 16 \\
\hline Largest kill reported (millions) & 50 & 30 & 2 & 4 & 22 & 8 & 2 & 1 & 18 & 3 \\
\hline \multicolumn{11}{|l|}{ Reports where extent of area } \\
\hline affected was stated & 106 & 114 & 70 & 67 & 54 & 61 & 77 & 68 & 52 & 34 \\
\hline \multicolumn{11}{|l|}{ Flowing waterbodies: } \\
\hline Number of events & 80 & 85 & 61 & 57 & 48 & 47 & 63 & 52 & 43 & 25 \\
\hline Miles of stream affected & 232 & 309 & 77 & 96 & 173 & 94 & 170 & 73 & 66 & 30 \\
\hline \multicolumn{11}{|l|}{ Lakes and reservoirs: } \\
\hline Number of events & 26 & 29 & 9 & 10 & 6 & 14 & 14 & 16 & 9 & 9 \\
\hline Acres affected & 16 & 113 & 1 & 1 & $<1$ & 2 & 3 & 6 & 1 & 1 \\
\hline
\end{tabular}




\section{Data Collection and Verification}

Data were obtained by either a state compiling and sending NOAA hard copy or digital files, or by the project team making a site visit. Site visits were made to Maryland, Virginia, Oregon, and Washington.

Information on fish-kill events and on the operation of reporting program(s) was collected from each state and entered into a NOAA data base. Data collected on each reported fishkill event included: 1) name and type of waterbody; 2) location (county, nearest town, and latitude and longitude coordinates where available); 3) date of kill; 4) cause of kill; $5)$ species and number of fish killed; 6) extent of area affected; and 7) duration of critical effects. Special emphasis was placed on obtaining information describing the cause of each event.

When the data provided for an event were insufficient to characterize the cause, the label "unspecified" was assigned. For a "land-use" cause, 60 percent of all records were assigned "unspecified"; for incident, 62 percent; and for direct cause, 21 percent. In cases where the cause reported did not reflect a naturally or human-induced change in water quality, the event was omitted. For example, kills caused by commercial fishing operations, recreational fishermen discards, underwater explosions, vandalism, spawning stress, stocking stress, catch and release stress, and entrapment in live bait boxes were omitted.

Figure 2. Summary of Fish-Kill Events from 1980-1989 for 22 Coastal States

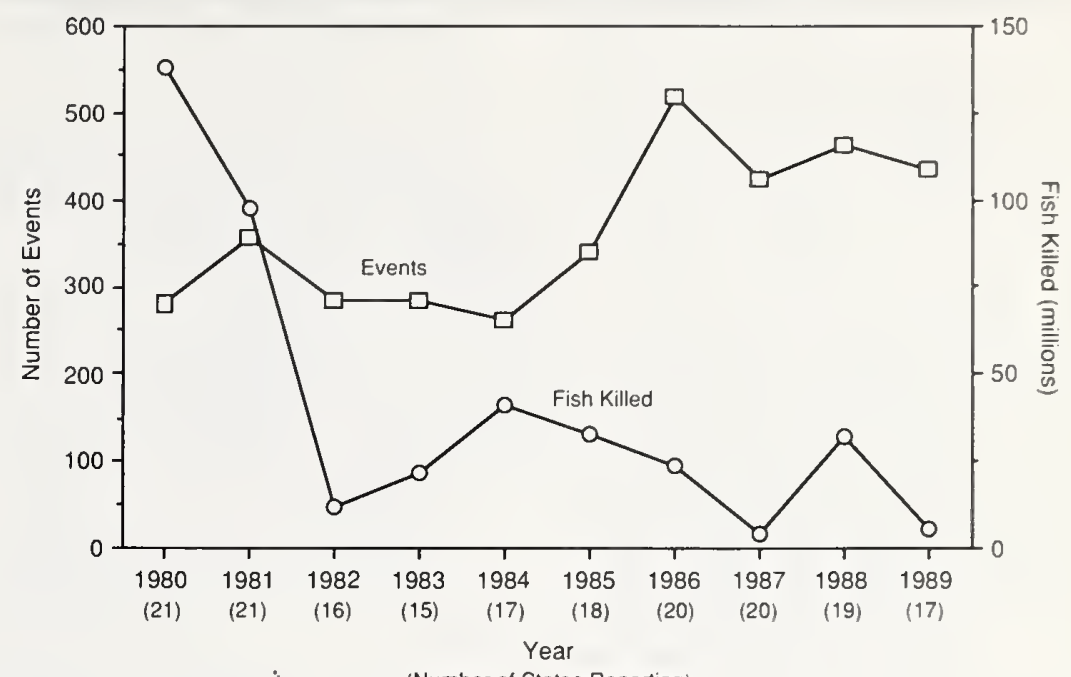

(Number of States Reporting)

\section{Major Data Elements for Each Event}

Land-use Cause identifies the type of land use from which a pollutant associated with an event originated (e.g., agricultural, industrial, urban, impoundment, silviculture, wildland, mining, or military operations). Events associated with eutrophication, lowdissolved oxygen, etc., were termed "water-related."

Source identifies the physical entity or activity from which a pollutant associated with an event originated (e.g., farm, industrial plant, wastewater treatment plant, or canal).

Incident describes the action that introduced a pollutant to a waterbody (e.g., runoff, routine or accidental releases, spill, spraying, natural, drawdown, and dredging or drilling activities)

Direct Cause lists the actual cause for a fish kill (e.g., low-dissolved oxygen, pesticide, stranding, $\mathrm{pH}$, temperature, or nutrients).

Specific Pollutant names the specific agent that caused a fish kill.

To verify the information collected, all data were reviewed by the participating State agencies.
This NOAA-developed data base was also compared to EPA's data base. Event records or parts of records were added, where appropriate. Sixty-two percent of the events in the NOAA data base came from State agencies, 7 percent from local agencies, and 31 percent from EPA.

Information was also collected on selected characteristics of each State's reporting program(s) to better understand the Nation's infrastructure for fish-kill reporting. Information on program organization, investigation procedures, on-site and offsite testing of fish tissue and water samples, documentation, distribution of fish-kill-related information, and use of the data and publications is presented in Appendix B.

\section{Limitations of the Data}

Interpretation of the data presented and any conclusions drawn must be tempered with a clear understanding of the limitations of the data. 
Figure 3. Sites of Major Fish-Kill Events from 1980-1989 for 22 Coastal States

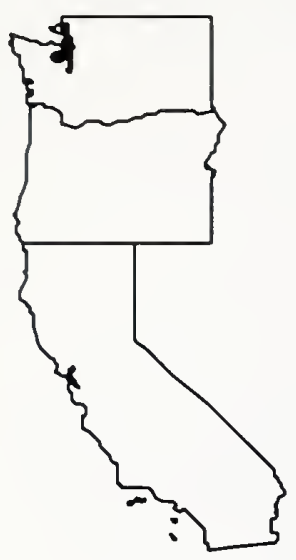

Major Kill Events ( $\geq 1$ million)

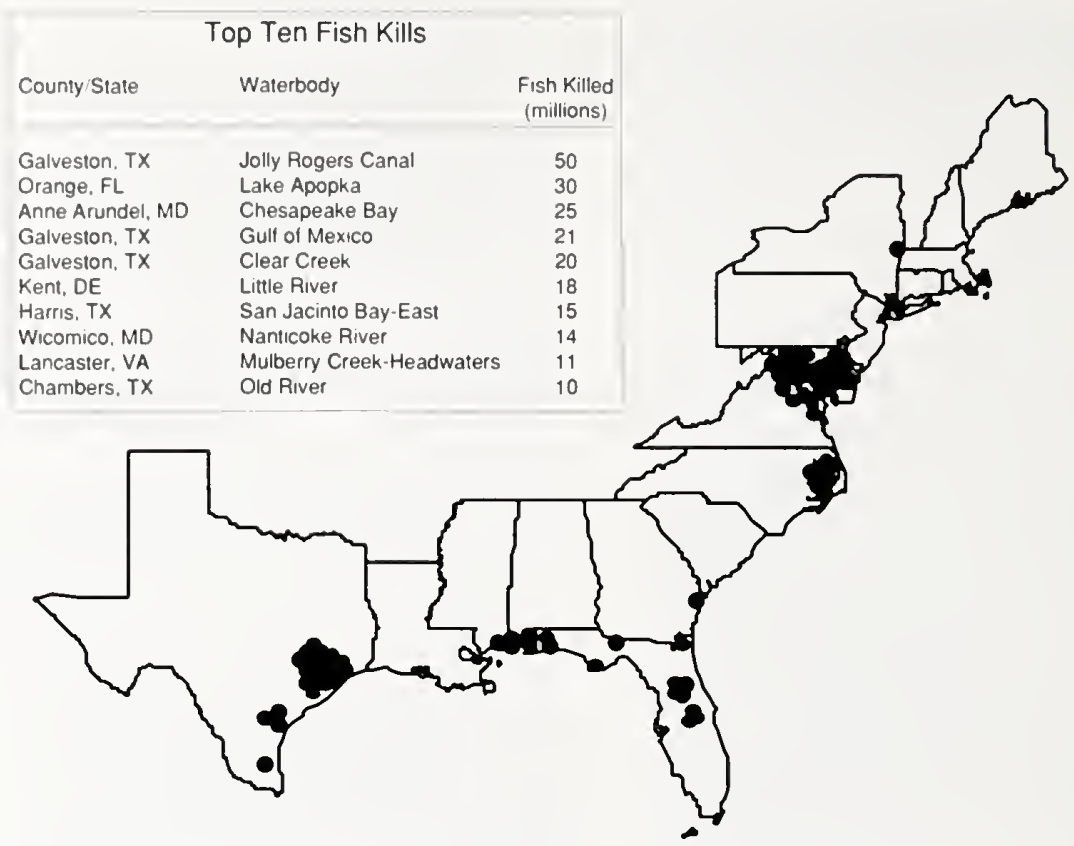

severity of an event. Nevertheless, almost 80 percent of all events contained some information on the direct cause and 84 percent contained at least an approximation of the number of fish killed.

\section{Factors that Influenced Re-} porting. The extent to which a fish-kill event is reported and how completely it is documented depends on several factors.

- How a state assigns responsibility for investigating fish kills. In some states, a single agency is responsible. In others, responsibility is assigned by geographic region or type of waterbody (fresh versus marine). In this case, fish-kill information is more dispersed and, therefore, more difficult to collect.

- The staff available to investigate events. In states with small budgets for fish-kill reporting programs, there may be an inadequate number of staff to investigate all events.

- The emphasis a state places on the type of event to investigate. For example, some states only investigate kills of economically important fish species, while other states respond to all kills.

- The size of the population surrounding a waterbody. Fish kills are reported more often around densely populated areas at least in part because more people witness and report the event. Kills occurring in sparsely settled areas often go unreported.

- The timeliness of the investigation. If the investigation does not take place promptly, fish wash downstream, sink, or are eaten by scavengers, lowering the number and possibly the species of fish reported killed. In addition, the contaminant or states, depending on available resources and the perceived 
environmental condition causing an event may be diluted or degraded so that a direct cause can no longer be attributed to a kill.

Although no absolute conclusions can be drawn from fish-kill data alone, combining the data with other information on pollution releases and environmental quality can provide useful insights to analysts and decisionmakers.

\section{National Results}

From 1980 to 1989 , over 3,650 fish-kill events were reported in 533 coastal and near coastal counties in 22 states. These events involved over 407 million fish. The number of events reported was highest in 1986 (519), and the greatest number of fish killed was in 1980 (138 million) (Table 1). The land-use cause, incident, and direct cause most frequently cited were urban land use, natural events, and low-dissolved oxygen.

\section{Trends and Seasonal Varia-}

tions. During the 10-year period, the number of states reporting events in estuarine and coastal waters varied from 15 in 1983 to 21 in 1980 and 1981 (Figure 2). Consequently, fishkill events are difficult to evaluate accurately over time. However, an upward trend exists in the number of events and a downward trend in the number of fish killed nationwide (Figure 2).

Seasonal variations play an important role in the timing of fish-kill events. As might be expected, the largest number of events $(64 \%)$ and the highest number of fish killed $(86 \%)$ were during the warmest months of the year (May through Septem- ber). The month with the single greatest number of events was August, while the greatest number of fish killed was in June.

\section{Geographical Distribution.}

States reporting the most fishkill events were Florida $(1,292)$, Maryland (455), Texas (355), and South Carolina (191). The top five counties with the greatest number of events were Palm Beach, FL (383); Broward, FL (277); Anne Arundel, MD (182); Dade, FL (87); and Beaufort, SC (73) (Appendix A).

States reporting the most fish killed were Texas (159 million), Florida (77 million), Maryland (68 million), Delaware (28 million) and North Carolina (26 million) (Appendix A). The top five counties with the greatest number of fish killed were Galveston, TX (106 million); Orange, FL (36 million); Anne Arundel, MD (36 million); Kent, DE (24 million); and Harris, TX (23 million) (Appendix A).

Sources and Causes. The land-use causes most frequently cited were urban $(13 \%)$, industrial $(7 \%)$, and agriculture (4\%). The top three incidents introducing pollutants into a waterbody were naturally occurring conditions (16\%), runoff $(7 \%)$, and routine releases $(5 \%)$. The direct causes most frequently cited were low-dissolved oxygen $(41 \%)$, wastewater $(5 \%)$, eutrophication $(5 \%)$, and pesticides (4\%).

\section{Major Fish Kills. Eighty-six} individual events occurred where an estimated one million or more fish were killed. These events took place in 39 counties within 14 states. The greatest concentration of these events was in Galveston (8) and Chambers (5) counties in Texas; Anne Arundel (8) and Wicomico (5) counties in Maryland; and Beaufort County (6), North Carolina.

The largest reported fish kill occurred in the Jolly Rogers Canal, Jamaica Beach, Galveston County, Texas, where an estimated 50-million fish died (Figure 3). The kill occurred in June 1980 and was attributed to low-dissolved oxygen from unspecified sources. The only species reported killed was gulf menhaden (Brevoortia patronus).

Many different combinations of land-use causes and direct causes result in major fish-kill events (Table 2). However, the majority of these events is characterized by low-dissolved oxygen, high temperatures (summer months), a large area of water with poor circulation, and involves small fish such as menhaden (Brevoortia sp.) that tend to school in large numbers and are very intolerant of lowdissolved oxygen conditions. Although events occur where a relatively toxic substance is released or spilled causing considerable damage to fish, these events occur less frequently and tend to be more localized, killing fewer fish.

The families of fish most commonly involved in a kill event are Clupeidae (menhaden, shad, herring), Centrarchidae (sunfish, bluegill, bass), and Cyprinidae (carps, minnows, dace, chubs, shiners). Of the above, Clupeidae are involved in 36 percent of all 


\section{Introduction}

fish-kill events and account for 61 percent of the total number of fish killed.

Five sections follow that present results for individual coastal regions: North Atlantic; Middle Atlantic; South Atlantic; Gulf of Mexico; and Pacific. The concluding comments section discusses potential uses of the data. Information on the number of events and fish killed by region, State, and county, and information on State reporting programs are provided in Appendices A and B.
Table 2. Land-Use Cause and Direct Cause of Major Fish Kills from 1980-1989 for 22 Coastal States

\begin{tabular}{|c|c|c|c|c|}
\hline $\begin{array}{l}\text { Land-use cause/ } \\
\text { Direct cause of kill }\end{array}$ & $\begin{array}{l}\text { Total } \\
\text { reports }\end{array}$ & $\%$ reports & $\begin{array}{l}\text { Number } \\
\text { of fish } \\
\text { (millions) }\end{array}$ & $\%$ fish killed \\
\hline \multicolumn{5}{|l|}{ Industry } \\
\hline Eutrophication. & 1 & 1 & 5 & 1 \\
\hline Wastewater & 1 & 1 & 1 & $<1$ \\
\hline Mixed Chemicals & 1 & 1 & 1 & $<1$ \\
\hline Pesticides & 1 & 1 & 1 & $<1$ \\
\hline Subtotal & 4 & 5 & 8 & $<1$ \\
\hline \multicolumn{5}{|l|}{ Urban } \\
\hline Low-Dissolved Oxygen & 1 & 1 & 1 & $<1$ \\
\hline Eutrophication & 1 & 1 & 1 & $<1$ \\
\hline Wastewater & 2 & 2 & 22 & 6 \\
\hline Mixed Chemicals & 1 & 1 & 30 & 8 \\
\hline Nutrients & 1 & 1 & 6 & 2 \\
\hline Subtotal & 6 & 7 & 60 & 16 \\
\hline \multicolumn{5}{|l|}{ Impoundments } \\
\hline Low-Dissolved Oxygen & 2 & 2 & 6 & 2 \\
\hline Temperature & 1 & 1 & 2 & 1 \\
\hline Subtotal & 3 & 3 & 8 & 2 \\
\hline \multicolumn{5}{|l|}{ Water-Related } \\
\hline Low-Dissolved Oxygen & 16 & 19 & 64 & 17 \\
\hline Temperature & 5 & 6 & 36 & 10 \\
\hline Eutrophication & 3 & 3 & 5 & 1 \\
\hline Stranding & 2 & 2 & 15 & 4 \\
\hline Storm Event & 1 & 1 & 3 & 1 \\
\hline Salinity Change & 3 & 3 & 7 & 2 \\
\hline Subtotal & 30 & 35 & 129 & 35 \\
\hline Unspecified & 43 & 50 & 169 & 45 \\
\hline Total & 86 & 100 & 375 & 100 \\
\hline
\end{tabular}



North Atlantic

Figure 4. Reported Fish-Kill Events by County, 1980-1989

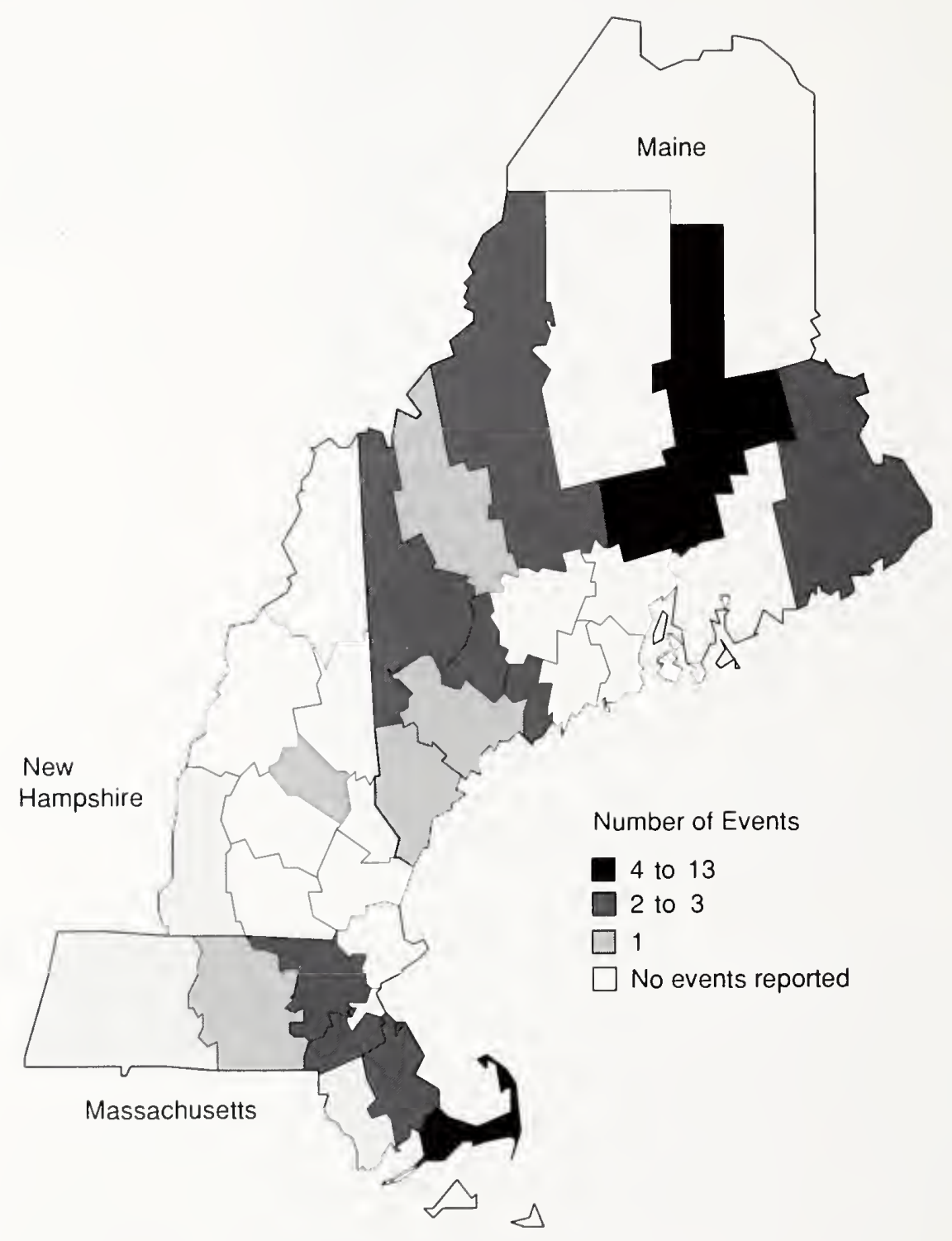

8 
The North Atlantic had the least number of events and least number of fish killed among regions. This can be partially explained by the climate and physical features of the estuaries in this region. The number of events reported each year was greatest during the summer months. The greatest number of events occurred in Penobscot County, Maine. Wastewater discharges, low-dissolved oxygen, and chemical releases were the three leading direct causes of fish kills.

\section{The Data}

In this region, 92 percent of reports included the number of fish killed, 84 percent included the direct cause of the event, 77 percent included the land-use cause, and 67 percent included the type of incident (Appendix A). This region had the second most complete reporting of the number of fish killed and direct causes among regions. Of the states in this region, Maine's reporting was the most complete and New Hampshire's was the least complete.

\section{Fish-Kill Events}

Fish-kill events were reported in 15 of the 31 counties in the study area (16 counties in Maine, 8 in New Hampshire, and 7 in Massachusetts) (Figure 4).

The North Atlantic had the fewest number of reported events (48) and least number of fish killed $(4,090,300)$. Maine accounted for over half of the fish-kill events reported in the region with 28 , followed by Massachusetts (19) and New Hampshire (1).
Figure 5. Number of Events and Fish Killed, 1980-1989

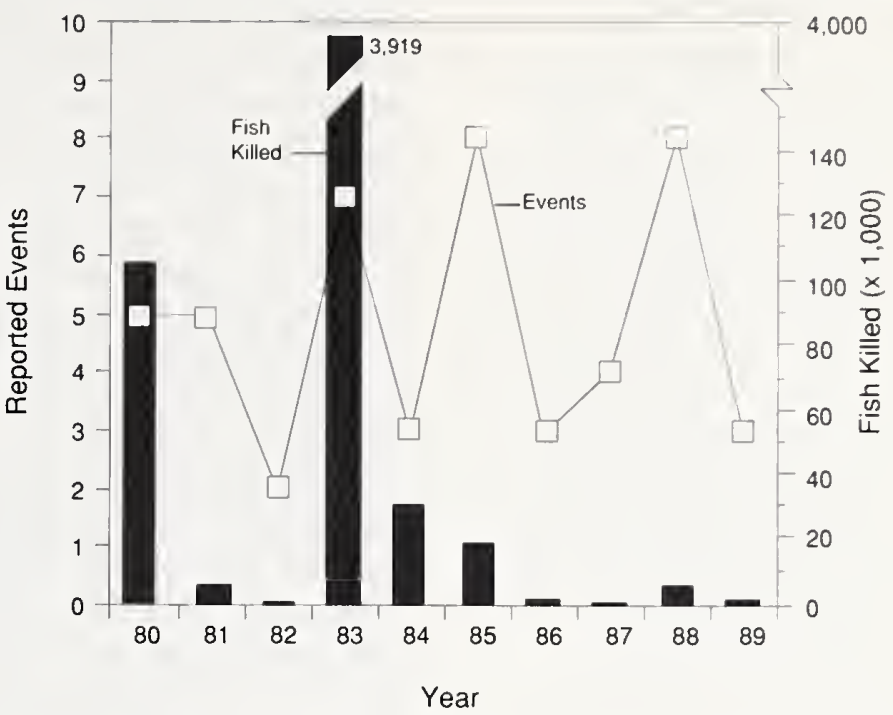

Massachusetts accounted for the majority of the fish killed in the region, with almost 3.9 million or 96 percent of all reported fish killed between 1980 and 1989. However, most of the total for Massachusetts can be attributed to one event that occurred in July 1983 in Wellfleet Harbor in Cape Cod Bay. Over 3.9 million fish were reported killed in this event. The incident was reported as a natural event, and the direct cause cited was low-dissolved oxygen. No other single event in the region accounted

for more than 100,500 fish killed.

Trends. The number of events reported from 1980 to 1989 does not appear to show a trend (Figure 5). However, an apparent seasonal pattern exists in the region. The majority of events and the greatest number of fish killed were reported in July, August, and September (Figure 6). This seasonal pattern exists across the Nation, with the majority of kills occurring during the summer months.

Figure 6. Number of Events and Fish Killed by Month, 1980-1989
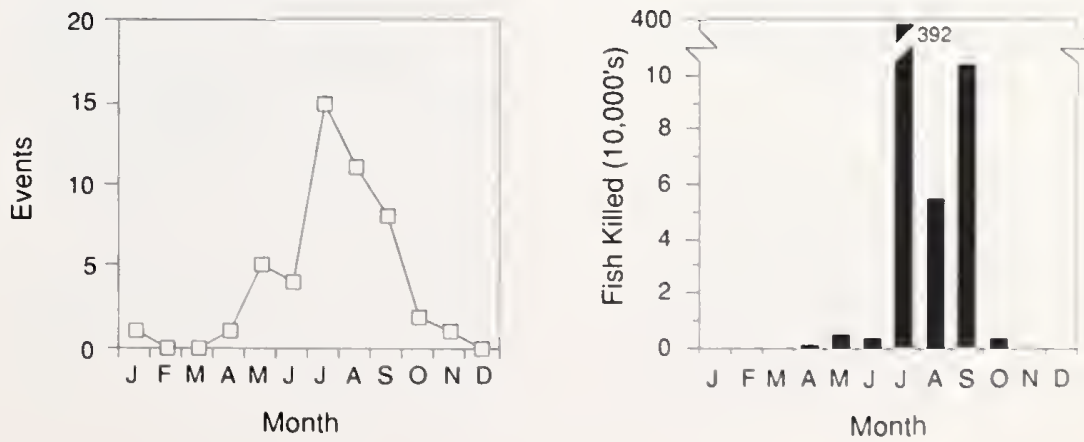


\section{Sources and Causes}

A number of factors may account for the relatively low number of fish kills observed in the North Atlantic. The climate of this region is colder than other regions. Therefore, fish are subjected to less thermal stress. The generally fastflowing rivers in the region and the strong tides and basin geometry in many of its estuaries result in well mixed and aerated waterbodies not highly susceptible to stratification and associated low-dissolved oxygen levels. This is in contrast to the more placid coastal plain rivers and shallow drowned-river systems in the Middle Atlantic, South Atlantic, and Gulf of Mexico. Finally, the North Atlantic covers the smallest land area of the five regions, has the lowest percentage of agricultural land (a potentially important land-use cause), and contains only 4 percent of all the existing point sources in the five coastal regions (NOAA, 1990). As a result, impacts due to human activities are less severe in this region.

The sources and causes of fish kills can be broken down into two different types of events. One type is related to human activities such as routine releases of wastewater or mixed chemicals from a variety of different sources (e.g., trucking accidents, various industries, sewage treatment plants, and pig farms).

Routine releases were the most frequently cited incidents causing these fish kills (Figure 7). The majority of the routine releases was emitted from industrial plants. Wastewater discharges, low-dissolved oxygen, and $\mathrm{pH}$ were the three leading direct causes of fish kills (Figure 8). Industry and agriculture were the two leading landuse causes associated with fish kills in the region (Figure 9).

The other type of event that led to a substantial number of kills in the region is naturally occurring phenomenon caused by a combination of environmental factors (i.e., water and air temperatures, wind, precipitation, and resident flora). Most of these events can be attributed to one or more of the following: low-dissolved oxygen; predatory stress; high temperatures; algal blooms; and/or bacterial infections.

In Maine, all 28 of the reported events indicated the direct cause of the kill. Wastewater was the direct cause in nine of the 28 events. Twenty-five of the 28 reported events indicated the land-use cause of the kill. Industrial land use was the landuse cause in 19 of the 25 events. In 25 of the 28 reported events, a direct cause was linked with a land-use cause.

In New Hampshire, the direct cause of the only reported fishkill event was inorganic chemicals/metals, and the land-use cause was urban land use.

In Massachusetts, 12 of the 19 reported events indicated the direct cause of the kill. Lowdissolved oxygen was the direct cause in four of the 12 events. Eleven of the 19 reported events indicated the land-use cause of the kill. Agricultural land use was the land-use cause in six of the 11 events. In nine of the 19 reported events, a direct cause was linked with a land-use cause.
Figure 7. Number of Fish-Kill Events by Type of Incident ${ }^{*}$

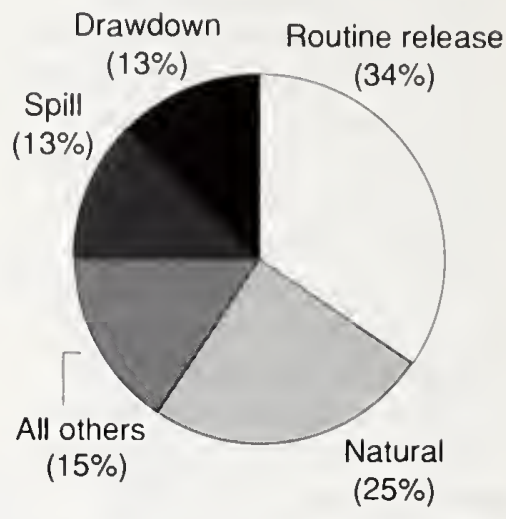

Figure 8. Number of Fish-Kill Events by Direct Cause*

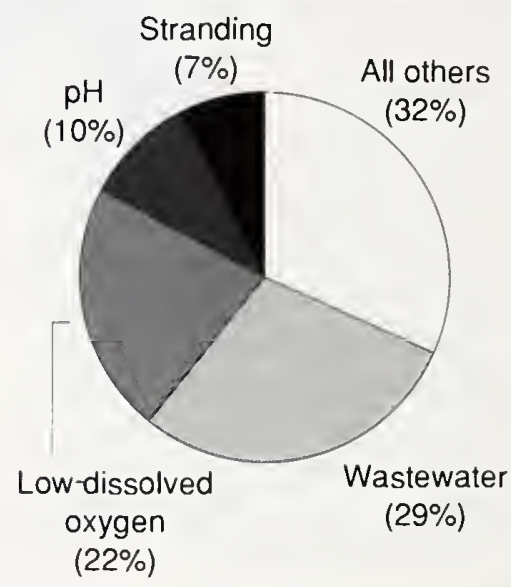

Figure 9. Number of Fish-Kill Events by Land-Use Cause*

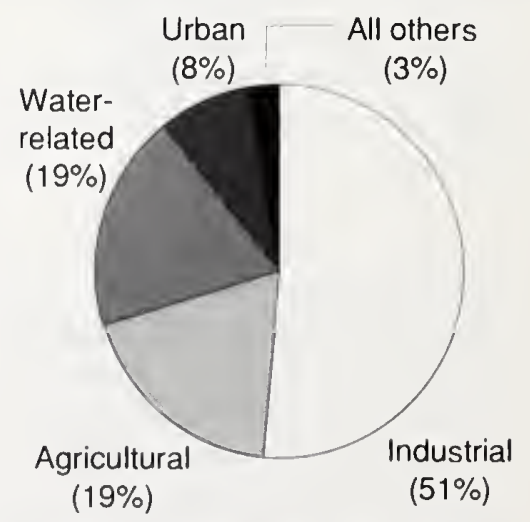

"Does not include information from unspecified events. 
Data tables containing the number of events and fish killed by county, state, region, year, direct cause, land-use cause, and incident are in Appendix A.

\section{Hotspots and Recurring Kills}

The greatest number of kills (13) in the region occurred in Penobscot County, Maine. Twelve of these were attributed to releases from industrial land use. This county contains 45 industrial sources, six of which are related to production of paper products.

\section{Mattanawcook stream in} Penobscot County was the site of nine fish-kill events between 1986 and 1989, eight of which were caused by a single pulp/ paper processing operation located on this stream. In 1989, the State took legal action against the plant. As a result, this plant has not been involved in any other reported fish-kill events. No other stream in the region had more than two events during the 10-year period.

The only other area in the region where a large number of kills was reported was Barnstable County, Massachusetts, with ten kills between 1980 and 1989 . However, most were due to natural causes.

\section{State Reporting Programs}

Each of the three North Atlantic states uses a different approach when collecting fish-kill data. The discussion below highlights which agencies in each state are involved in fish-kill reporting and when they are most likely to make an on-site investigation of a fish-kill event. Information concerning each state's program organization, investigative procedures, and use of data are summarized in Appendix B.

Maine has three agencies that may be involved in the fish-kill investigation process: the Department of Environmental Protection (DEP); Department of Inland Fisheries and Wildlife; and the Department of Marine Resources. DEP is the only organization that provided fishkill data to NOAA. The state indicated that field visits are likely to be made when an event is reported (i.e., more than 75 percent of the time).

New Hampshire's Marine Division, within the Department of Fish and Game, has primary responsibility for all fish kills occurring in the state. They also provided fish-kill data for this report. They conduct field investigations of fish-kill events approximately 5 percent of the time and are more likely to respond to an event if large numbers of fish are involved in the kill.

Massachusetts has the largest program of the three North Atlantic states. The responsibility is shared between two agencies: Division of Marine Fisheries (marine- and coastalrelated kills), and the Division of Fisheries and Wildlife (freshwater kills). Both provided fish-kill data to NOAA. They also reported that field visits are standard procedure when an event is reported (i.e., more than 75 percent of the time). 


\section{Middle Atlantic}

Figure 10. Reported Fish-Kill Events by County, 1980-1989

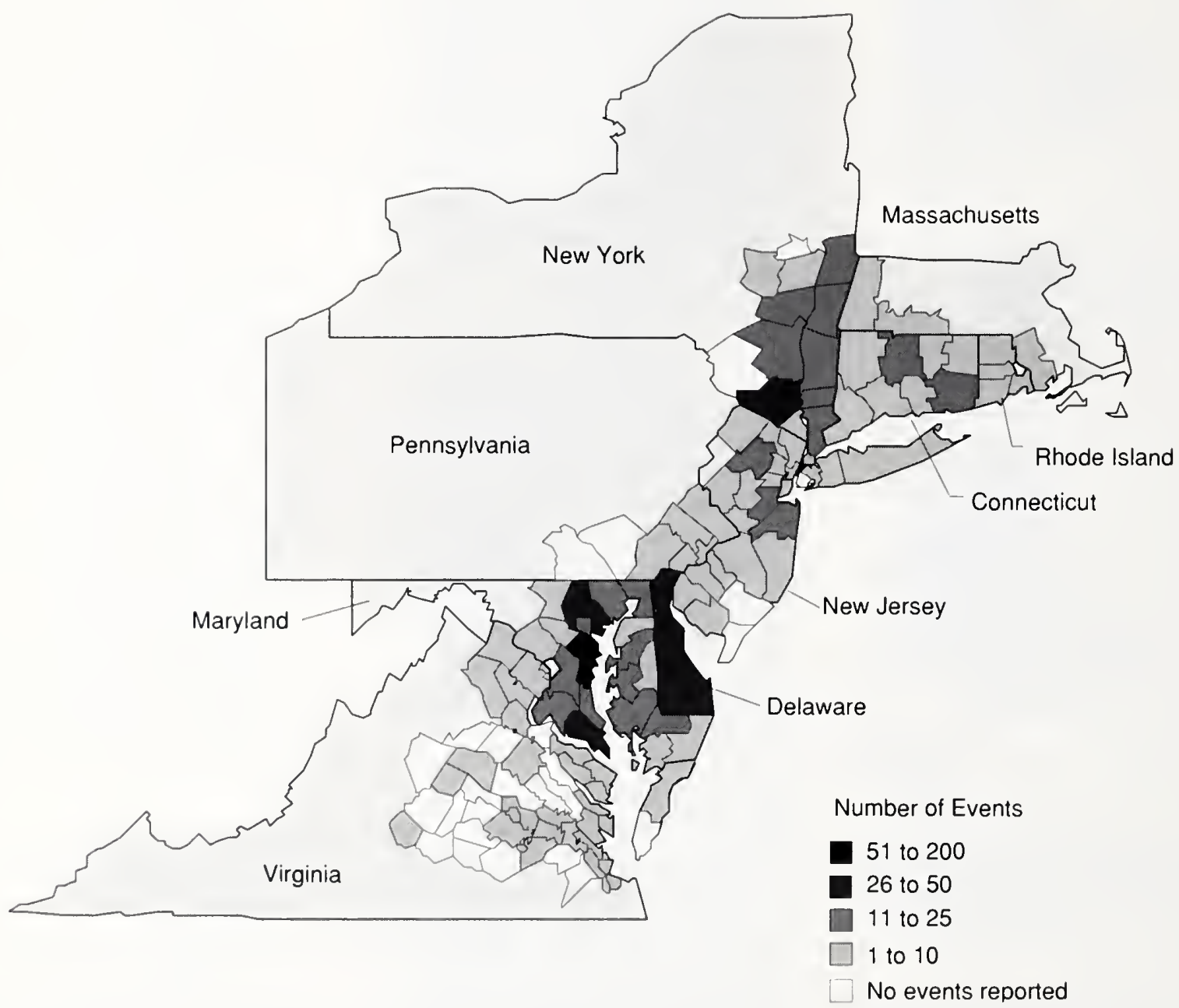


The Middle Atlantic had the second highest number of events and number of fish killed among regions. This can be partially explained by the climate and physical features of the estuaries in this region. The number of events reported each year was greatest during the summer months. The greatest number of events occurred in Anne Arundel County, Maryland. Lowdissolved oxygen, disease, and wastewater discharges were the three leading direct causes of fish kills.

\section{The Data}

Assessment of the important sources and causes of events in this region is hampered by the gaps in cause-related information reported by each state. In this region, 65 percent of the reports included the number of fish killed, 69 percent included the direct cause of the event, 48 percent included the land-use cause, and 45 percent included the type of incident (Appendix A). The Middle Atlantic had the most incomplete reporting of the number of fish killed and direct causes among regions. Of the states in this region,

Connecticut's reporting was the most complete and New Jersey's was the most incomplete.

\section{Fish-Kill Events}

Fish-kill events were reported in 113 of the 149 counties (including the District of Columbia) in the study area ( 5 counties in Massachusetts, 5 in Rhode Island, 8 in Connecticut, 20 in New York, 20 in New Jersey, 7 in Pennsylvania, 3 in Delaware, 21 in Maryland including the
Figure 11. Number of Events and Fish Killed, 1980-1989

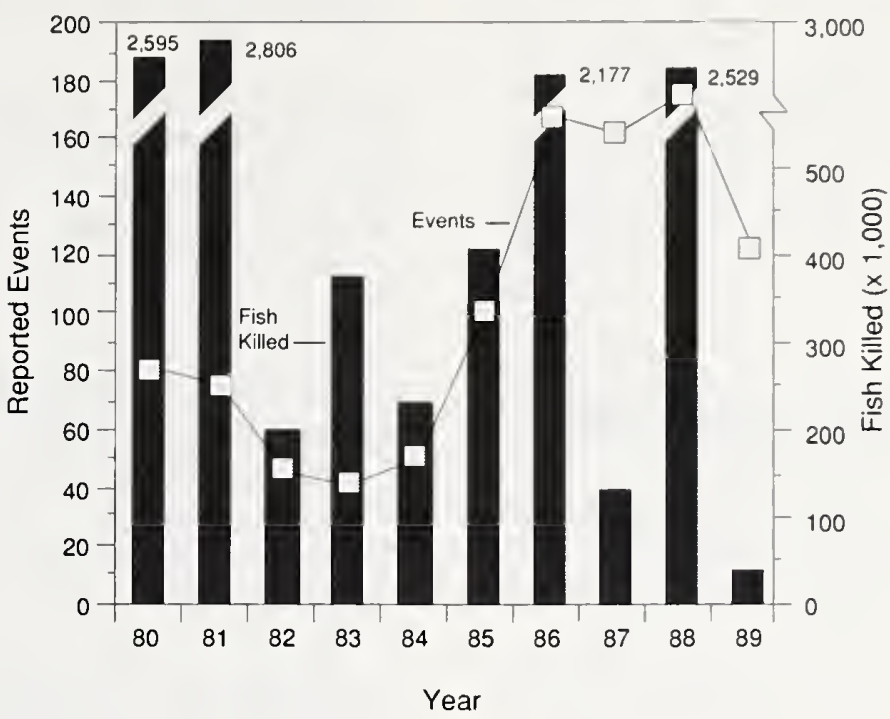

District of Columbia, and 60 in Virginia) (Figure 10).

This region had the second highest number of reported events $(1,033)$ and fish killed $(115,339,200)$. Maryland accounted for over one-third of the fish-kill events reported in the region (455), followed by New York (151); Delaware (120); New Jersey (112); Virginia (98); Connecticut (55); Rhode Island (18); Pennsylvania (16); and Massachusetts (8).

Maryland also had the highest number of fish killed in the region, with about 68 million or

59 percent of all reported fish killed between 1980 and 1989 Twenty events in Maryland involved the death of over a million fish. Eight of these occurred in Anne Arundel County and five in Wicomico County.

Trends. The number of events reported from 1980 to 1989 shows an upward trend (Figure 11). From 1980 to 1984 , the largest number of fish-kill events occurring in a single year was 81 in 1980 . However, from 1985 to 1989 , at least 100 events occurred each year, with the largest being 177 in 1988. A seasonal pattern also exists in

Figure 12. Number of Events and Fish Killed by Month, 1980-1989
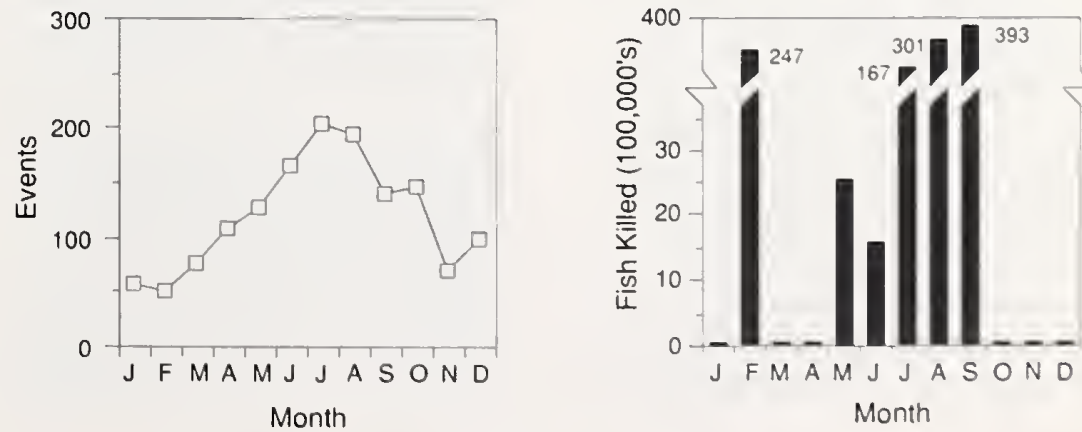


\section{Middle Atlantic}

this region. Most events were reported between June and August (Figure 12). However, the greatest numbers of fish killed were reported in February, August, and September. This seasonal pattern exists across the Nation, with the majority of kills occurring during the summer months.

\section{Sources and Causes}

A number of factors may account for the relatively high number of fish kills in the Middle Atlantic.

The shallow drowned-river systems in the region and the weak tides and basin geometry in many of its estuaries result in poorly mixed and aerated waterbodies susceptible to stratification and associated lowdissolved oxygen levels. This region also has the greatest human population density and the greatest percentage of urban land among regions (NOAA, 1990).

Naturally occurring events dominate the region, with the top two direct causes reported as low-dissolved oxygen levels and disease (Figures 13 and 14). In addition, a significant impact is caused by routine wastewater releases and/or spills occurring in urban and industrial land-use areas (Figure 15). These events reflect kills related to inputs from human activities.

In Massachusetts, five of the eight reported events indicated the direct cause of the kill. Lowdissolved oxygen was the direct cause reported in two of the five events. Three of the eight reported events indicated the land-use cause of the kill. Industrial land use was the landuse cause in two of the three events. In only three of the eight events was a land-use cause reported along with a direct cause.

In Rhode Island, 13 of the 18 reported events indicated the direct cause of the kill. Lowdissolved oxygen was the direct cause in nine of the 13 events. Five of the 18 reported events indicated the land-use cause of the kill. Urban land use was the land-use cause in two of the five events. A direct cause was associated with a land-use cause in only five of the 18 reported events.

In Connecticut, 42 of the 55 reported events indicated the direct cause of the kill. Lowdissolved oxygen was the direct cause in nine of the 42 events. Seventeen of the 55 reported events indicated the land-use cause of the kill. Industrial land use was the land-use cause in six of the 17 events. In only 16 of the 55 reported events was a direct cause linked with a specific land use.

In New York, 116 of the 151 reported events indicated the direct cause of the kill. Lowdissolved oxygen was the direct cause in 18 of the 116 events. Ninety-three of the 151 reported events indicated the land-use cause of the kill. Impoundments were the land-use cause identified in 33 of the 93 events. In 86 of the 151 reported events, a land-use cause was reported along with a direct cause.

In New Jersey, 64 of the 112 reported events indicated the direct cause of the kill. Pesticides were the direct cause in nine of the 64 events. Thirtythree of the 112 reported events indicated the land-use cause of
Figure 13. Number of Fish-Kill Events by Type of Incident*

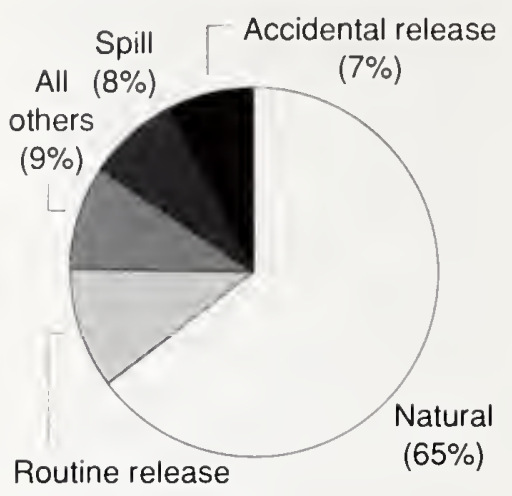

(11\%)

Figure 14. Number of Fish-Kill Events by Direct Cause*

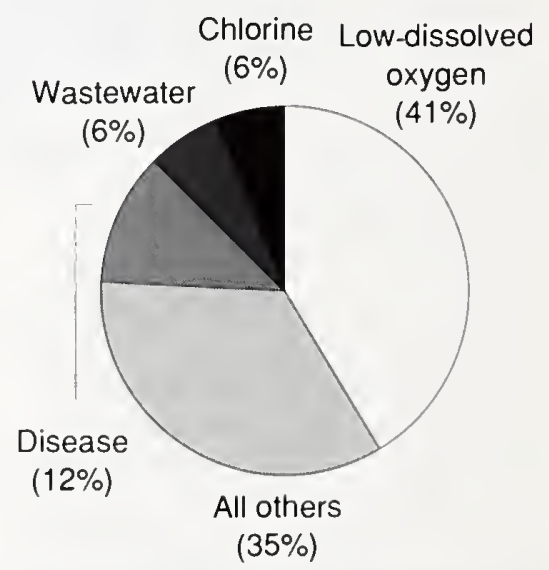

Figure 15. Number of Fish-Kill Events by Land-Use Cause*

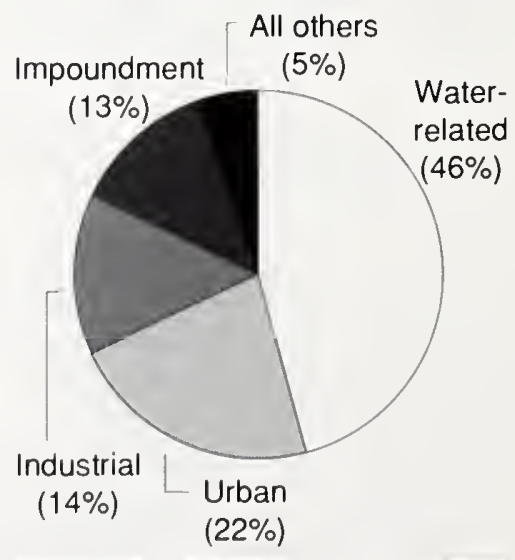

"Does not include information from unspecified events. 
the kill. Urban land use was the land-use cause in 16 of the 33 events. A direct cause was associated with a specific land use in only 31 of the 112 reported events.

In Pennsylvania, ten of the 16 reported events indicated the direct cause of the kill. Pesticides were the direct cause in three of the ten events. Thirteen of the 16 reported events indicated the land-use cause of the kill. Urban land use was the land-use cause in six of the 13 events. In 10 of the 16 reported events, a direct cause was linked with a land-use cause.

In Delaware, 72 of the 120 reported events indicated the direct cause of the kill. Lowdissolved oxygen was the direct cause in 36 of the 72 events. Thirty-three of the 120 reported events indicated a land-use cause of the kill. Urban land use was the land-use cause in ten of the 33 events. In only 30 of the 120 reported events was a land-use cause reported along with a direct cause.

In Maryland, 333 of the 455 reported events indicated the direct cause of the kill. Lowdissolved oxygen was the direct cause in 200 of the 333 events. Of the 455 reported events, 249 indicated the land-use cause of the kill. Water-related land use was the land-use cause in 188 of the 249 events. A direct cause was associated with a specific land use in 241 of the 455 reported events.

In Virginia, 60 of the 98 reported events indicated the direct cause of the kill. Lowdissolved oxygen was the direct cause in 12 of the 60 events. Fifty of the 98 reported events indicated the land-use cause of the kill. Industrial land use was the land-use cause in 17 of the 50 events. In 49 of the 98 reported events, the land-use cause was linked with the direct cause.

Data tables containing the number of events and fish killed by county, state, region, year, direct cause, land-use cause, and incident are in Appendix A.

\section{Hotspots and Recurring Kills}

Two counties in Maryland reported the highest number of fish-kill events for the Middle Atlantic region. One hundred and eighty-two events were reported in Anne Arundel County (accounting for $31 \%$ of all reported fish kills in the region), and 47 events occurred in Baltimore County. Most of these kills were attributed to lowdissolved oxygen levels.

The waterbody having the most events in this region was the Magothy River Basin (43 events) in Anne Arundel County, Maryland. This river has a history of over-enrichment problems. However, this situation was further exacerbated in February 1986 when the waste from a break in a sewage line was discharged into the river. Twenty-four of the 43 reported events for this river occurred between May and October 1986. The Hudson River/Raritan Bay area, which traverses seven New York counties and four New Jersey counties, was another waterbody for which numerous events were reported. Nineteen fish-kill events were reported for this waterbody between 1980 and 1989. However, most of the records for these events did not contain information on the cause of the kills.

\section{State Reporting Programs}

Each of the nine Middle Atlantic states uses a different approach when collecting fish-kill data. The discussion below highlights which agencies in each state are involved in fishkill reporting and when they are most likely to make an on-site investigation of a fish-kill event. Information concerning each state's program organization, investigative procedures, and use of data are summarized in Appendix B.

Massachusetts (see the North Atlantic region).

Rhode Island has three different divisions within the Department of Environmental Management (DEM) that may be involved in the fish-kill investigation process. These divisions are Enforcement (handles initial response and assessment), Fish and Wildlife (responds only if kill occurs in a pond or lake, or if only one fish species is involved and less than 100 fish are killed), and Water Resources (handles pollution-related kills and works jointly with Fish and Wildlife on large kills). The Water Resources Division is the only office that provided fish-kill data for this report. However, because each division should provide full documentation to each other for all fish kills, data provided should be complete for the state. Before May 1988. the state had no formal fish kill response policy. Now, field visits are made when: a large number of fish is involved (this state's cutoff is 100 fish): the public becomes concerned; and/or personnel are available to respond. 


\section{Connecticut has two divisions}

(Water Management and

Fisheries) under the Depart-

ment of Environmental Protec-

tion (DEP) that respond to and

document fish kills. The Water

Management Division is

primarily concerned with kills

caused by industrial dis-

charges, while the Fisheries

Division responds to and

investigates all kills. Only

Fisheries provided fish-kill data

for this report (their response

included data from both divi-

sions). The Fisheries contact

indicated that field visits are

generally standard procedure

when an event is reported.

New York has five divisions within its Department of Environmental Conservation (DEC) that may be involved in the fishkill investigation process: Fish and Wildlife; Law Enforcement; Water; Hazardous Substances Regulation; and Marine and Coastal Resources. The Fish and Wildlife Division provided statewide fish-kill data for this report. An on-site investigation is made when a large number of fish is involved in the kill and/ or when the public becomes concerned.

New Jersey has two divisions within the Department of Environmental Protection that respond to fish-kill events. The Fish, Game, and Wildlife Division handles inland kills, while the Marine Fisheries Division responds to coastal water kills. However, only the Fish, Game, and Wildife regional offices provided fish-kill data for this report. Field visits are likely to be made when a large number of fish is involved or when the public becomes concerned.
Pennsylvania's fish-kill program consists of three agencies: the Department of Environmental Resources' Bureau of Water Quality; the Fish Commission's Bureau of Law Enforcement; and the Emergency Management Agency. Due to a staff shortage at the Fish Commission, fish-kill data for this report were obtained from the EPA data base. Field visits to fish-kill sites are made the majority of the time (i.e., more than 75 percent of the time).

Delaware's program is conducted by the Department of Natural Resources and Environmental Control's (DNREC) Division of Fish and Wildlife. The Fish and Wildlife Division provided fish-kill data for this report. It reports that field visits are standard procedure and they respond more than 75 percent of the time.

Maryland's program is conducted by the Water Quality Monitoring Division, Department of the Environment. The Water Quality Monitoring Division provided fish-kill data for this report. Field visits are likely to be made when a large number of fish is involved in a kill or when the public becomes concerned.

Virginia has two agencies that may be involved in the fish-kill investigation process: the Water Control Board (WCB) and the Department of Game and Inland Fisheries. The WCB provided fish-kill data for this report. Field visits are likely to be made when a large number of fish is involved in the kill, the public becomes concerned, and/or personnel are available to respond. 

South Atlantic

Figure 16. Reported Fish-Kill Events by County, 1980-1989

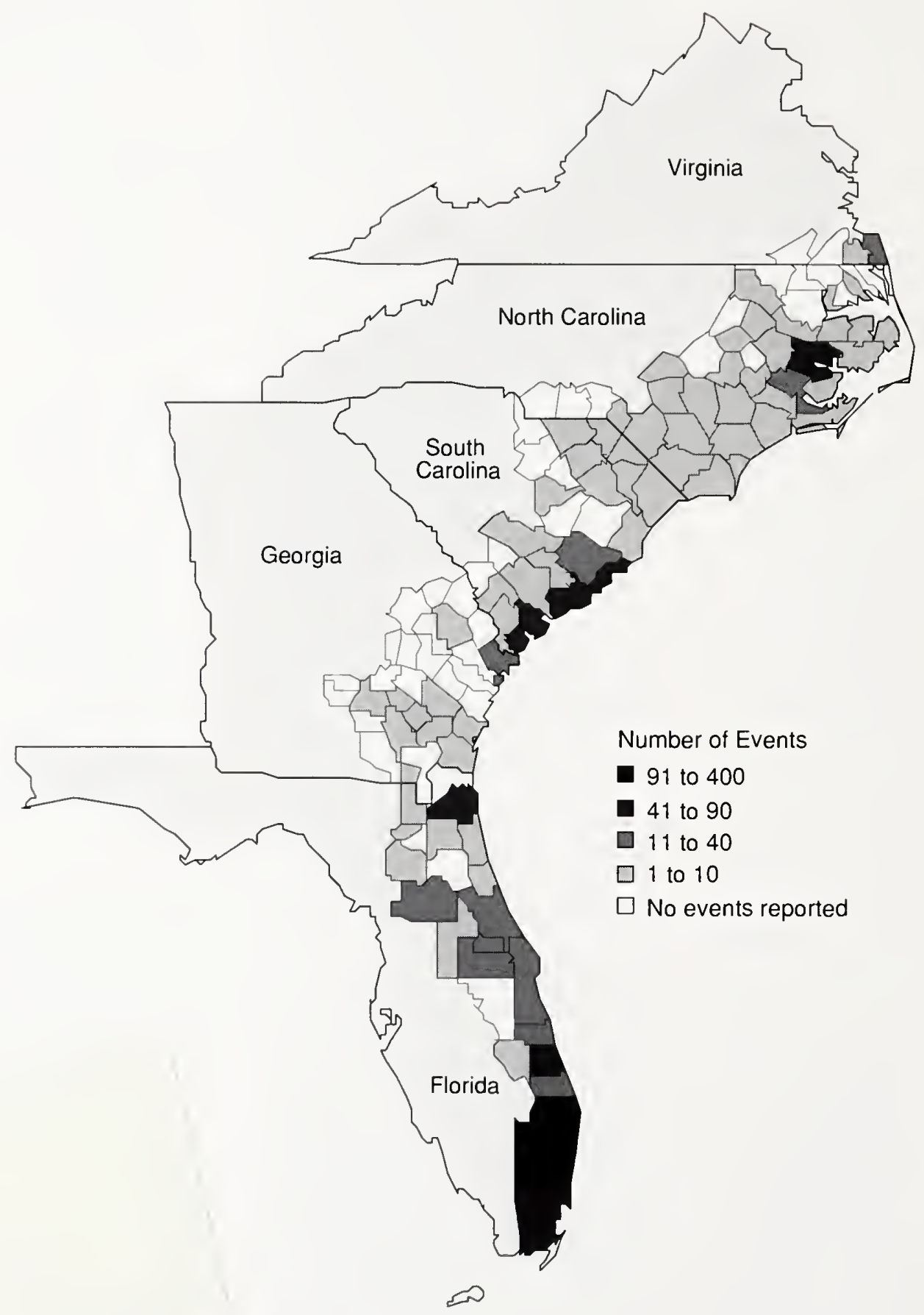

18 
The South Atlantic had the highest number of events and the third highest number of fish killed among regions. This can be partially explained by the climate and physical features of the estuaries in this region. The number of events reported each year was greatest during the summer months. The greatest number of events occurred in Palm Beach County, Florida. Low-dissolved oxygen, eutrophication, and pesticides were the three leading direct causes of fish kills.

\section{The Data}

In this region, 96 percent of the reports included the number of fish killed, 84 percent included the direct cause of the event, 26 percent included the land-use cause, and 25 percent included the type of incident (Appendix A). The South Atlantic had the most complete reporting of the direct cause and number of fish killed among regions. Of the states in this region, Florida's reporting was the most complete and Georgia's was the most incomplete.

\section{Fish-Kill Events}

Fish-kill events were reported in 79 of the 125 counties in the study area (4 in Virginia, 44 in North Carolina, 24 in South Carolina, 29 in Georgia, and 24 in Florida) (Figure 16).

This region had the highest number of reported events $(1,450)$ and third highest number of fish killed $(95,291,300)$. Florida accounted for almost three quarters of the fish-kill events reported in the region with
Figure 17. Number of Events and Fish Killed, 1980-1989

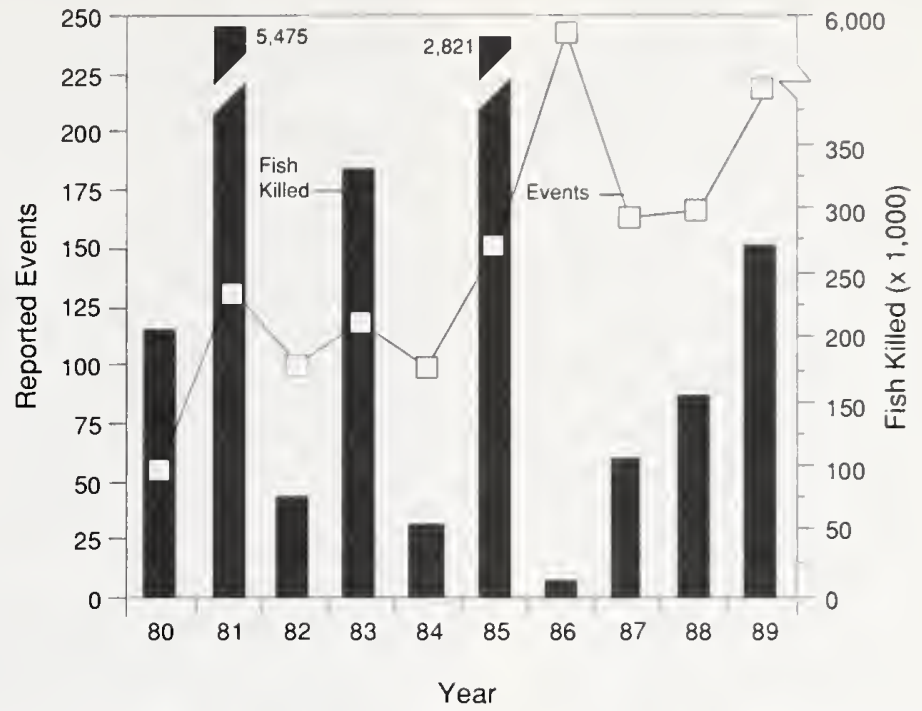

1,042 , followed by South Carolina (191); North Carolina (153); Georgia (33); and Virginia (31).

shows an upward trend (Figure 17). From 1980 to 1984 , the largest number of fish-kill events occurring in a single year was 133 in 1981 . However, from 1985 to 1989 , at least 150 events occurred each year, with the largest being 243 in 1986. An apparent seasonal pattern also exists in this region. The majority of events and the greatest number of fish killed were reported between June and August (Figure 18). This seasonal pattern exists across the Nation, with the majority of kills occurring during the summer months.

Trends. The number of events reported from 1980 to 1989

Figure 18. Number of Events and Fish Killed by Month, 1980-1989
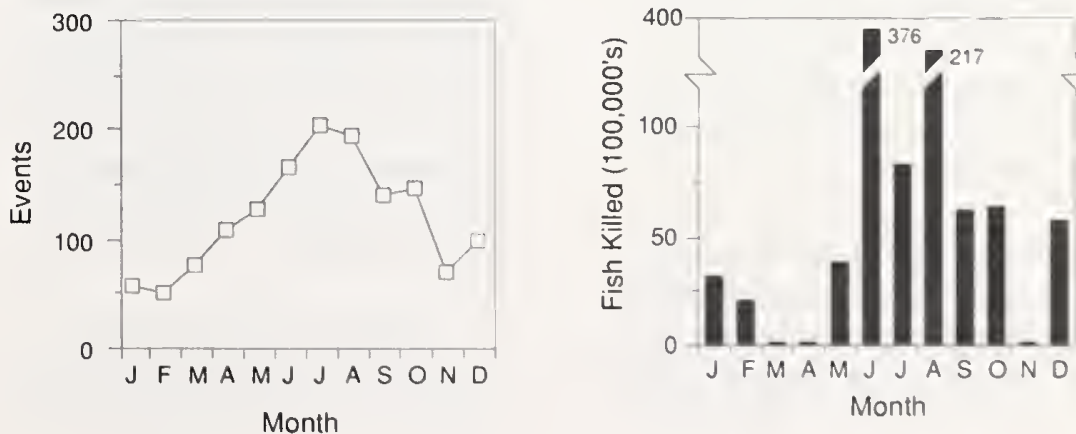


\section{Sources and Causes}

A number of factors may account for the relatively high number of fish kills observed in the South Atlantic. The shallow drowned-river systems in the region and the weak tides and basin geometry in many of its estuaries result in poorly mixed and aerated waterbodies susceptible to stratification and associated low-dissolved oxygen levels. This region also has the second largest total estuarine drainage area, the highest intensity of pesticide application, and the second highest application rate of nutrients among regions (NOAA, 1990).

Kills associated with runoff from urban and agricultural land use dominate the region, with the top two direct causes reported as low-dissolved oxygen levels and eutrophication (Figures 19, 20 and 21). In addition, naturally occurring events had a significant impact on the waterbodies in this region (Figure 19).

In Virginia, 21 of the 31 reported events indicated the direct cause of the kill. Lowdissolved oxygen was the direct cause reported in eight of the 21 events. Fifteen of the 31 reported events indicated the land-use cause of the kill.

Water-related land use was the land-use cause in eight of the 15 events. In 15 of the 31 reported events, a land-use cause was reported along with a direct cause.

In North Carolina, 108 of the 153 reported events indicated the direct cause of the kill. Lowdissolved oxygen was the direct cause in 38 of the 108 events.
Seventy-nine of the 153 reported events indicated the land-use cause of the kill. Water-related land use was the land-use cause in 42 of the 79 events. In 78 of the 153 reported events, a direct cause was associated with a land-use cause.

In South Carolina, 138 of the 191 reported events indicated the direct cause of the kill. Lowdissolved oxygen was the direct cause in 60 of the 138 events. Nineteen of the 191 reported events indicated the land-use cause of the kill. Urban land use was the land-use cause in 12 of the 19 events. In only 17 of the 191 reported events was a direct cause linked with a specific landuse cause.

In Georgia, 27 of the 33 reported events indicated the direct cause of the kill. Wastewater discharge was the direct cause in six of the 27 events. Twenty-two of the 33 reported events indicated the land-use cause of the kill. Urban land use was the land-use cause identified in 11 of the 22 events. In 22 of the 33 reported events, a land-use cause was reported along with a direct cause.

In Florida, 929 of the 1,042 reported events indicated the direct cause of the kill. Lowdissolved oxygen was the direct cause in 728 of the 929 events. Two hundred and thirty-nine of the 1,042 reported events indicated the land-use cause of the kill. Urban land use was the land-use cause in 158 of the 239 events. In only 228 of the 1,042 reported events was a direct cause associated with a specific land-use cause.

Data tables containing the number of events and fish killed by county, state, region, year,
Figure 19. Number of Fish-Kill Events by Type of Incident*

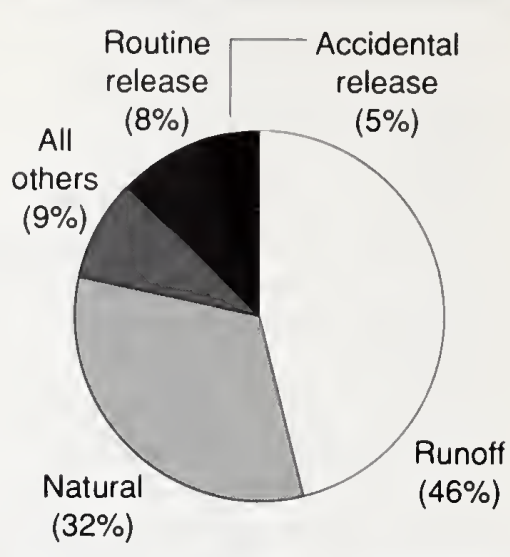

Figure 20. Number of Fish-Kill Events by Direct Cause*

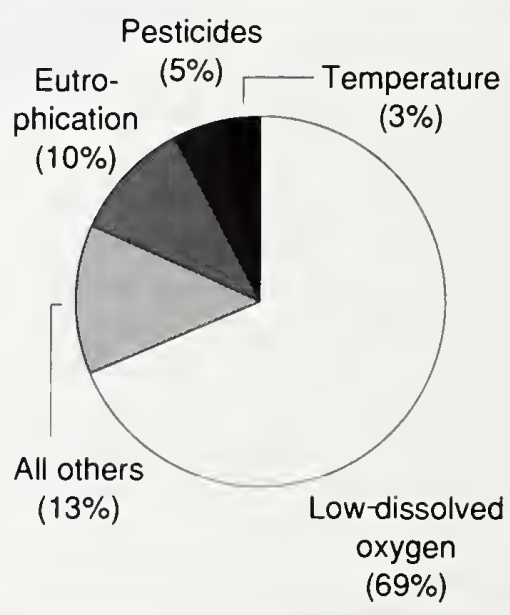

Figure 21. Number of Fish-Kill Events by Land-Use Cause*

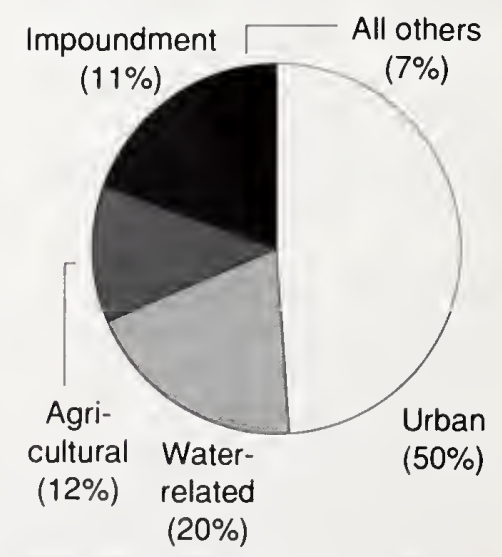

"Does not include information from unspecified events. 
direct cause, land-use cause, and incident are in Appendix A.

\section{Hotspots and Recurring Kills}

Two counties in Florida reported the highest number of fish-kill events for the South Atlantic region. Three hundred and eighty-three events were reported in Palm Beach County (accounting for $37 \%$ of all reported fish kills in the region), and 277 events occurred in Broward County. Most of these kills were attributed to lowdissolved oxygen levels.

The St. Johns River Basin which traverses six Florida counties (Brevard, Clay, Duval, Marion, Seminole, and Volusia) was the waterbody for which the most events (29) were reported in this region. This river has a history of over-enrichment problems.

The river also receives discharges of irrigation water from surrounding agricultural farms (citrus and sugarcane fields). Over half of the events were caused by low-dissolved oxygen conditions. The Pamlico River, which flows through three North Carolina counties (Beaufort, Hyde, and Pamlico), was another waterbody for which numerous events were reported. Twenty-three fish-kill events were reported for this waterbody between 1981 and 1989. The majority of the reports cited some type of naturally occurring condition as the direct cause such as low-dissolved oxygen levels, disease, bacteria, fungus, and/or changes in salinity.

Florida and North Carolina have set up special programs to monitor these two waterbodies because these coastal waters were under severe environmental stress.

\section{Florida - A Special Case}

Florida ranks first in number of events $(1,292)$ and number of fish killed (over 77 million) among states. Several reasons help to explain this. First, the entire state $(54,153$ sq. mi. $)$ is defined as "coastal" (Bureau of Census, 1988). The state with the second largest area is California $(39,575$ sq. mi.) (NOAA, 1987).

Second, Florida has a large number of artificial canals, lakes, and impoundments located in and around residential subdivisions. These waters are prone to eutrophication problems. Kills occurring in them are easily observed and frequently reported because of their proximity to the surrounding communities.

Third, the state's high year-round temperatures and extremely high summer temperatures greatly contribute to kills associated with low-dissolved oxygen levels and eutrophication.

\section{State Reporting Programs}

Each of the five South Atlantic states uses a different approach when collecting fish-kill data. The discussion below highlights which agencies in each state are involved in fishkill reporting and when they are most likely to make an on-site investigation of a fish-kill event. Information concerning each state's program organization, investigative procedures, and use of data are summarized in Appendix B.

Virginia (see the Middle Atlantic region).
North Carolina's fish-kill program is primarily covered by three agencies: the Department of Environment, Health, and Natural Resources (responds to all kills to help determine cause); the Department of Crime Control and Public Safety (involved with emergency management and pollution testing); and the Wildlife Commission (deals with surveying kill sites to determine number and species of fish killed, and their economic value). In addition, through a cooperative effort between two divisions (Environmental Management and Marine Fisheries) in the Department of Environment Health and Natural Resources, the Pamlico Estuarine Response Team (PERT) was formed in 1988 to respond to the increasing number of fish-kill events in the Pamilco River/Sound. The Department of Environment, Health, and Natural Resources' Division of Environmental Management provided fish-kill data for this report. It reported that field visits are standard procedure, and they respond more than 75 percent of the time.

South Carolina's fish-kill program is run by two agencies: the Bureau of Solid and Hazardous Waste Management in South Carolina's Department of Health and Environmental Control (SCDHEC); and the Department of Wildlife and Marine Resources. The Department of Wildife and Marine Resources is primarily concerned with kills occurring in public waters, while the SCDHEC responds and investigates all kills. Only SCDHEC provided fish-kill data for this report. An on-site 


\section{South Atlantic}

investigation is made when a large number of fish is involved in the kill and/or when the public becomes concerned.

Georgia has three divisions within its Department of Natural Resources that may be involved in the fish-kill investigation process: Environmental Protection (initial contact and response that confirms a fish-kill event); Coastal Resources (investigates marine and coastal water kills); and Game and Fish Division (investigates freshwater events). The Coastal Resource and the Game and Fish Divisions provided fish-kill data for this report. They reported that field visits are standard procedure and that they respond more than 75 percent of the time.

Florida's fish-kill reporting is primarily covered by two agencies: the Department of Environmental Regulation (DER) which consists of a central office and six district offices; and the Game and Freshwater Fish Commission which consists of a central and five regional offices. The central office and one of the district offices of the DER, four of the regional offices of the Game and Freshwater Fish Commission, and the Bioenvironmental Services Division of Duval County all provided fish-kill data for this report. The central DER office reported that field visits are likely to be made when the public becomes concerned. 

Figure 22. Reported Fish-Kill Events by County, 1980-1989

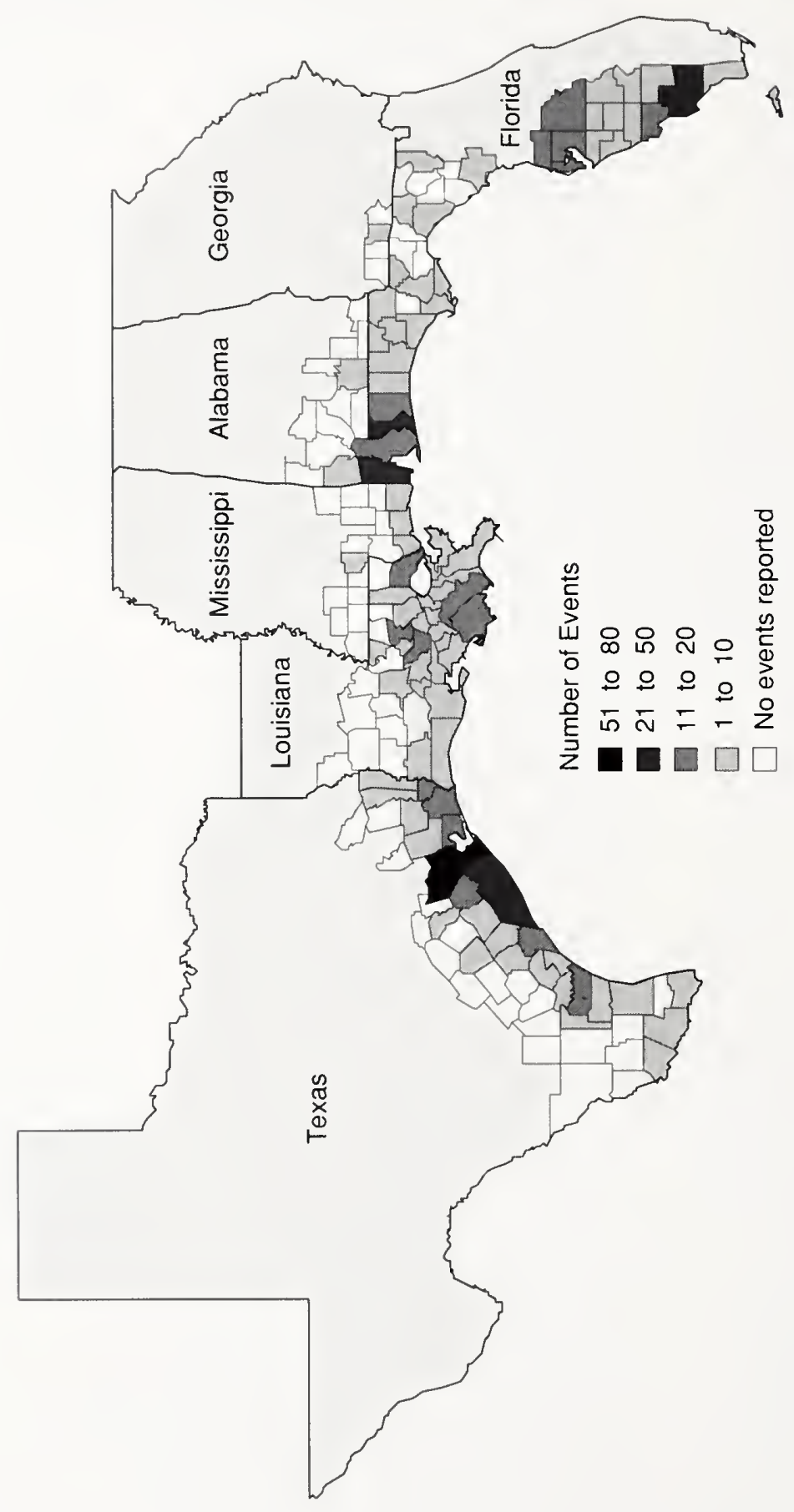


The Gulf of Mexico had the third highest number of events and the highest number of fish killed among regions. This can be partially explained by the climate and physical features of the estuaries in this region. The number of events reported each year was greatest during the summer months. The greatest number of events occurred in Galveston County, Texas. Lowdissolved oxygen, storm events, and wastewater discharges were the three leading direct causes of fish kills.

\section{The Data}

In this region, 75 percent of the reports included the number of fish killed, 84 percent included the direct cause of the event, 54 percent included the land-use cause, and 50 percent included the type of incident (Appendix A). The Gulf of Mexico had the fourth most complete reporting of the direct cause and number of fish killed among regions. Of the states in this region, Alabama's reporting was the most complete and Louisiana's was the most incomplete.

\section{Fish-Kill Events}

Fish-kill events were reported in 100 of the 164 counties in the study area (4 counties in Georgia, 43 in Florida, 14 in Alabama, 17 in Mississippi, 39 in Louisiana, and 47 in Texas) (Figure 22).

This region had the third highest number of reported events (830) and the highest number of fish killed $(188,161,000)$. Texas accounted for almost half of the fish-kill events reported in the
Figure 23. Number of Events and Fish Killed, 1980-1989

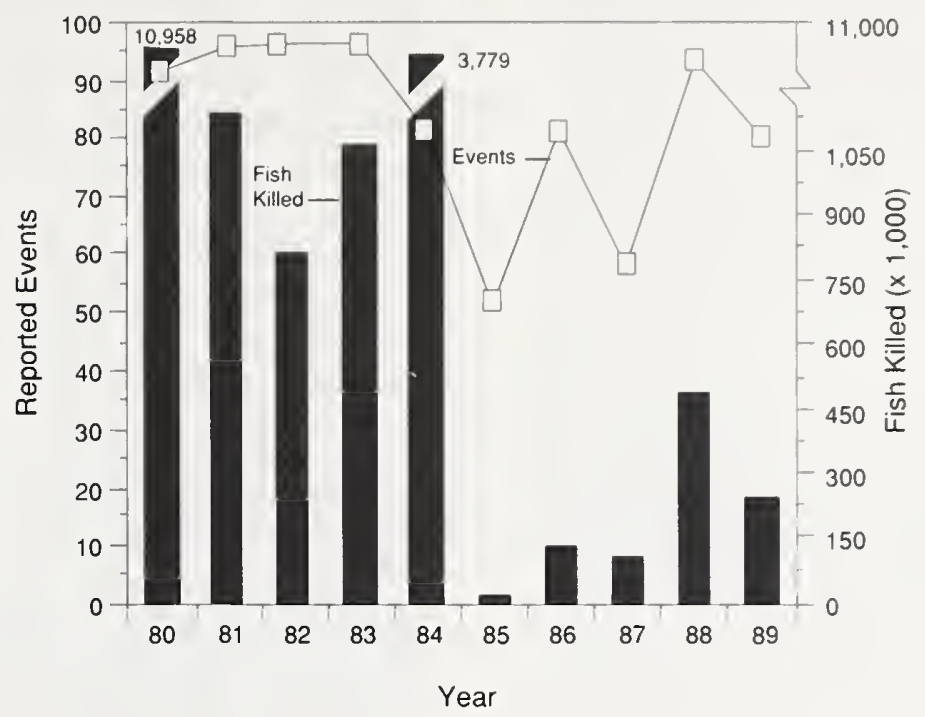

region (355), followed by Florida (250); Louisiana (172); Alabama (44); Mississippi (7); and Georgia (2).

Texas also had the highest number of fish killed in the region, with approximately 159 million or 85 percent of all reported fish killed between 1980 and 1989. Twenty-one events in Texas involved the death of over a million fish. Eight of these occurred in Galveston County and five in Chambers County.

Trends. The number of events reported from 1980 to 1989 does not show any trend (Figure 23).

However, an apparent seasonal pattern exists in this region. Most events were reported during May, August, and September (Figure 24). However, the greatest numbers of fish killed were reported in June, August, and September (Figure 24). This seasonal pattern exists across the Nation, with the majority of kills occurring during the summer months.

\section{Sources and Causes}

A number of factors may account for the relatively high number of events and fish killed

Figure 24. Number of Events and Fish Killed by Month, 1980-1989
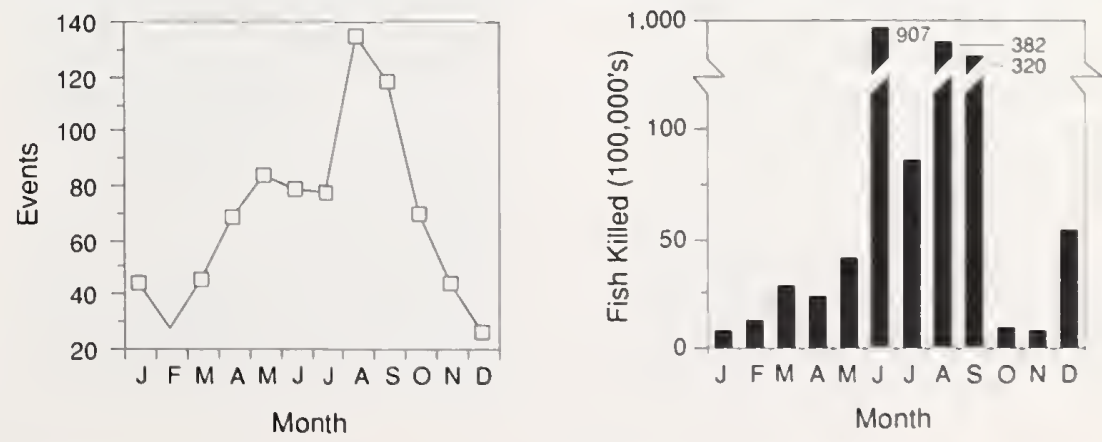
in the Gulf of Mexico. This region has the highest percentage of agricultural land, application of fertilizers and pesticides, industrial point sources, and municipal wastewater treatment plants among regions (NOAA, 1990). Estuaries in this region have an average depth of eight feet, the shallowest among regions, which restricts their ability to assimilate the loadings of pollutants mentioned above (NOAA, 1990). These factors, in addition to the hot/humid climate, contribute to waterbodies that are frequently nutrient-enriched and thermally stressed. The result is frequent low-dissolved oxygen levels, particularly in the summer, that can lead to fish kills.

Naturally occurring events dominate the region, with the top two direct causes reported as low-dissolved oxygen levels and wastewater (Figures 25 and 26). In addition, a significant impact is caused by runoff from storm events in urban areas and/or by routine and accidental releases from industrial land uses (Figure 27). These events reflect kills related to impacts from human activities.

In Florida, 219 of the 250 reported events indicated the direct cause of the kill. Lowdissolved oxygen was the direct cause reported in 116 of the 219 events. Of the 250 reported events, 109 indicated the landuse cause of the kill. Urban land use was the land-use cause in 56 of the 109 events. In only 106 of the 250 events was a land-use cause reported along with a direct cause.

In Georgia, one of the two reported events indicated the direct cause of the kill. Wastewater was the direct cause in this event. Both of the reported events indicated the land-use cause of the kill. Industrial and urban land use were the landuse causes for these events. A direct cause was associated with a land-use cause in one of the two reported events.

In Alabama, 40 of the 44 reported events indicated the direct cause of the kill. Lowdissolved oxygen was the direct cause in 23 of the 40 events. Sixteen of the 44 reported events indicated the land-use cause of the kill. Urban land use was the land-use cause in ten of the 16 events. In only 16 of the 44 reported events was a direct cause linked with a specific land-use cause.

In Mississippi, six of the seven reported events indicated the direct cause of the kill. A change in salinity was the direct cause in three of the six events. Five of the seven reported events indicated the land-use cause of the kill. Water-related land use was the land-use cause identified in all five of the events. In five of the seven reported events, a land-use cause was reported along with a direct cause.

In Louisiana, 146 of the 172 reported events indicated the direct cause of the kill. Lowdissolved oxygen was the direct cause in 63 of the 146 events. Of the 172 reported events, 108 indicated the land-use cause of the kill. Impoundments were the land-use cause in 36 of the 108 events. A direct cause was associated with a specific landuse cause in 107 of the 172 reported events.

In Texas, 291 of the 355 reported events indicated the direct cause of the kill. Low-
Figure 25. Number of Fish-Kill Events by Type of Incident*

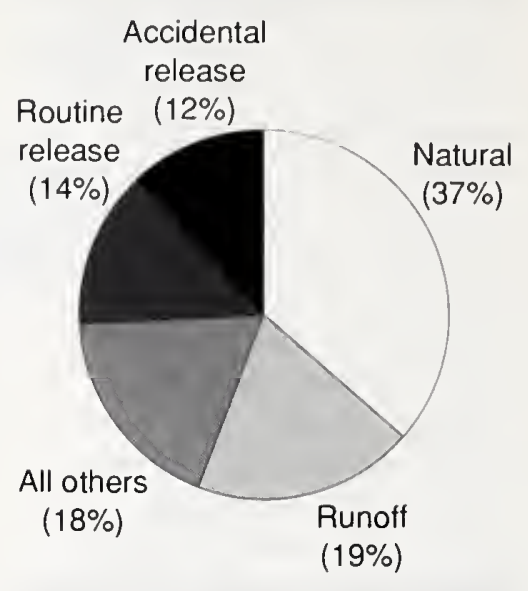

Figure 26. Number of Fish-Kill Events by Direct Cause*

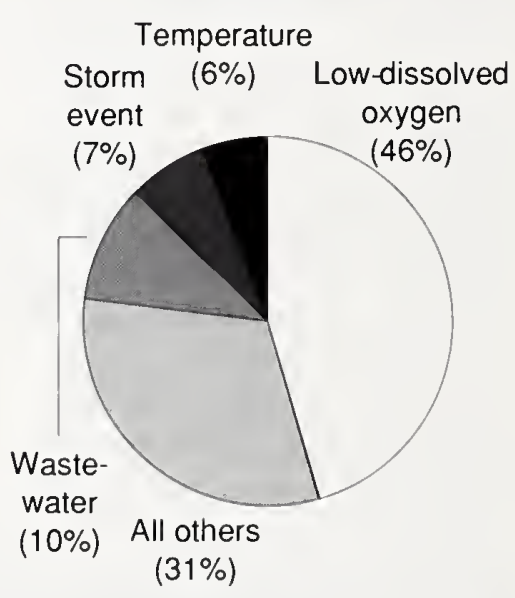

Figure 27. Number of Fish-Kill Events by Land-Use Cause*

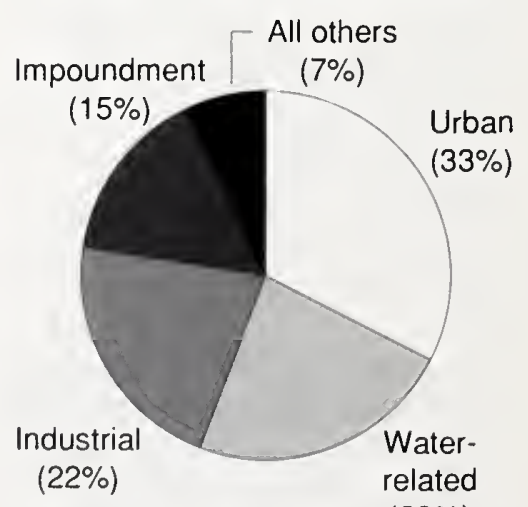

$(23 \%)$

"Does not include information from unspecified events. 
dissolved oxygen was the direct cause in 119 of the 291 events. Of the 355 reported events, 208 indicated the land-use cause of the kill. Water-related land use was the land-use cause in 67 of the 208 events. A direct cause was associated with a specific land-use cause in 201 of the 355 reported events.

Data tables containing the number of events and fish killed by county, state, region, year, direct cause, land-use cause, and incident are in Appendix A.

\section{Hotspots and Recurring Kills}

Two counties in Texas reported the highest number of fish-kill events for the Gulf of Mexico region: Galveston County (72) and Harris County (66). Galveston County had the highest number of fish killed (almost 106 million) of all the counties in the entire study area. Half of these kills were attributed to low-dissolved oxygen levels that were not associated with a land-use cause.

Galveston Bay was the waterbody for which the most events (28) were reported in this region. Large portions of Brazoria, Chambers, Galveston, Harris, and Liberty counties are in the Galveston Bay estuarine drainage area (EDA). Taken together, these counties contain the highest concentration of point sources in the Nation's coastal area. Fifteen percent of all industrial point sources and municipal wastewater treatment plants in the study area are located in the Galveston Bay EDA. Seventeen of the 28 kills in the Galveston Bay EDA were related to low-dissolved oxygen and temperature. Five of the 17 events were caused by releases of cooling water from power plants.

The only other area in the region where a large number of kills was reported was Collier County in Florida, with 49 events between 1980 and 1989. Most of these kills were due to lowdissolved oxygen and/or excessive nutrient loadings.

\section{State Reporting Programs}

Each of the six Gulf of Mexico states uses a different approach when collecting fish-kill data. The discussion below highlights which agencies in each state are involved in fish-kill reporting and when they are most likely to make an on-site investigation of a fish-kill event. Information concerning each state's program organization, investigative procedures, and use of data are summarized in Appendix B.

Florida (see the South Atlantic region).

Georgia (see the South Atlantic region).

Alabama has two agencies that may be involved in the fish-kill investigation process: the Department of Environmental Management (DEM) and the Department of Conservation and Natural Resources. The DEM provided the fish-kill data for this report. Field visits to fish-kill sites are made more than 75 percent of the time.

Mississippi has two agencies that may be involved in the fishkill investigation process: the Department of Environmental Quality (DEQ); and the Depart- ment of Wildlife, Fisheries and Parks. The two bureaus within DEQ are Pollution Control (responsible for all state waters) and Marine Resources (may investigate some coastal kills). The Bureau of Pollution Control is the office that provided the fish-kill data for this report. Field visits to fish-kill sites are made more than 75 percent of the time.

Louisiana's fish-kill program is conducted by three agencies: the Department of Environmental Quality (DEQ); the Department of Wildlife and Fisheries (DWF); and the Department of Agriculture. The DWF investigates kills caused by naturally occurring fish diseases, while the $D E Q$ responds to and investigates all kills. DEQ provided the fish-kill data for this report. The DEQ contact indicated that field visits are generally made when an event is reported.

Texas has two different agencies that respond to and document fish kills: the Texas Park and Wildlife Department (TPWD) and the Texas Water Commission (TWC). The TWC has the lead on water-quality problems relating to discharges, while the TPWD responds to, investigates, and is responsible for recovering damages to fish and wildlife for all kills. The TPWD provided statewide fishkill data for this report. Field visits are likely to be made when: a large number of fish is involved in a kill; the public becomes concerned; personnel are available to respond; a responsible party can be identified; and/or the kill may be related to a particular cause or contaminant. 


\section{Pacific}

Figure 28. Reported Fish-Kill Events by County, 1980-1989

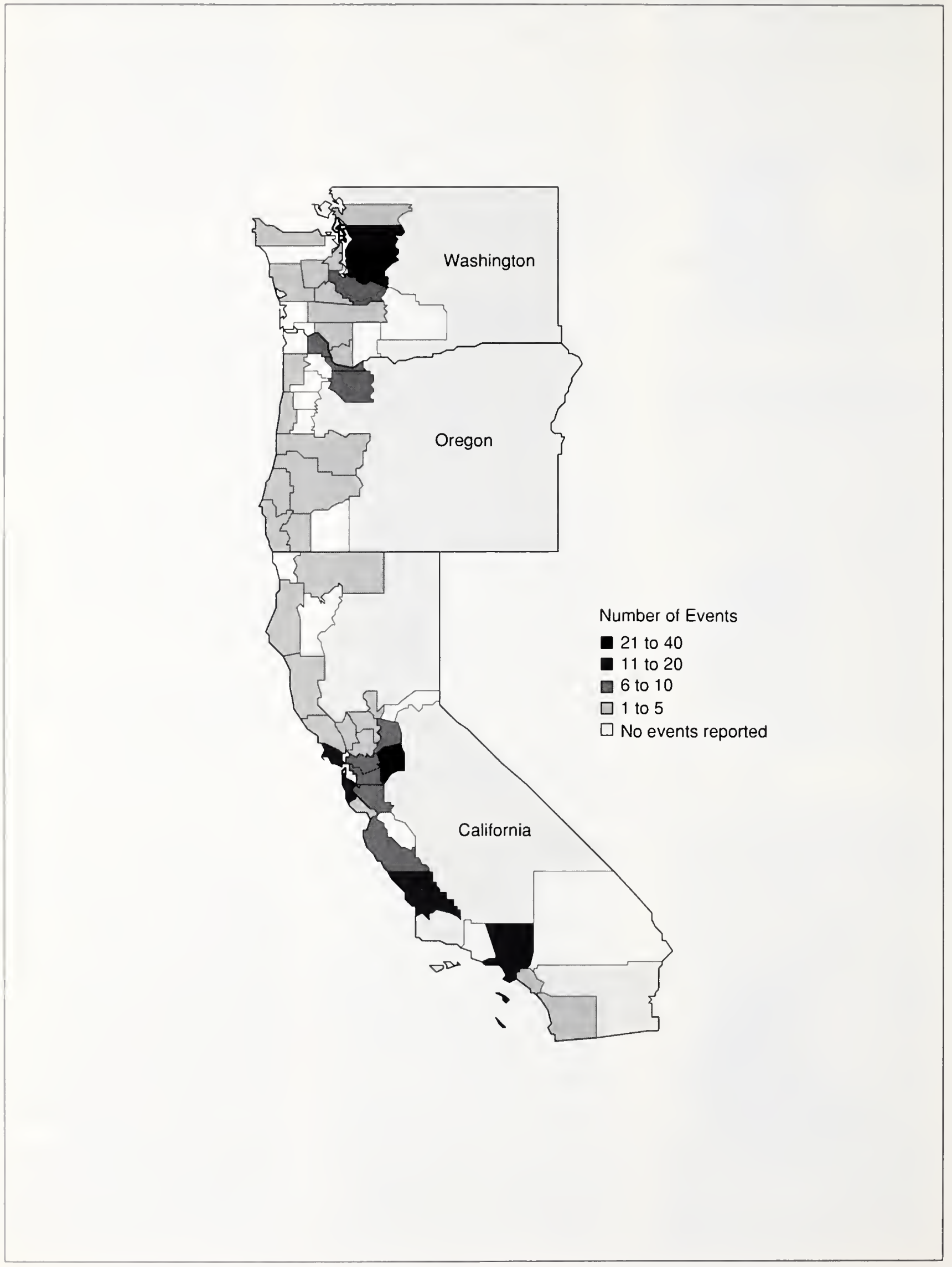


The Pacific had the fourth highest number of events and number of fish killed among regions. This can be partially explained by the climate and physical features of the estuaries in this region. The number of events reported each year was greatest during the summer months. The greatest number of events occurred in King County, Washington. Lowdissolved oxygen, pesticides, and animal wastes were the three leading direct causes of fish kills.

\section{The Data}

In this region, 88 percent of the reports included the number of fish killed, 73 percent included the direct cause of the event, 47 percent included the land-use cause, and 39 percent included the type of incident (Appendix A). The Pacific had the third most complete reporting of the direct cause and number of fish killed among regions. Of the states in this region, California's reporting was the most complete and Washington's was the most incomplete.

\section{Fish-Kill Events}

Fish-kill events were reported in 47 of the 64 counties in the study area (29 counties in California, 16 in Oregon, and 19 in Washington) (Figure 28).

This region had the fourth highest number of reported events (293) and fish killed $(4,281,100)$. California accounted for over half of the fishkill events reported in the region with 148 , followed by Washington (105); and Oregon (40).

Washington had the highest number of fish killed in the
Figure 29. Number of Events and Fish Killed, 1980-1989

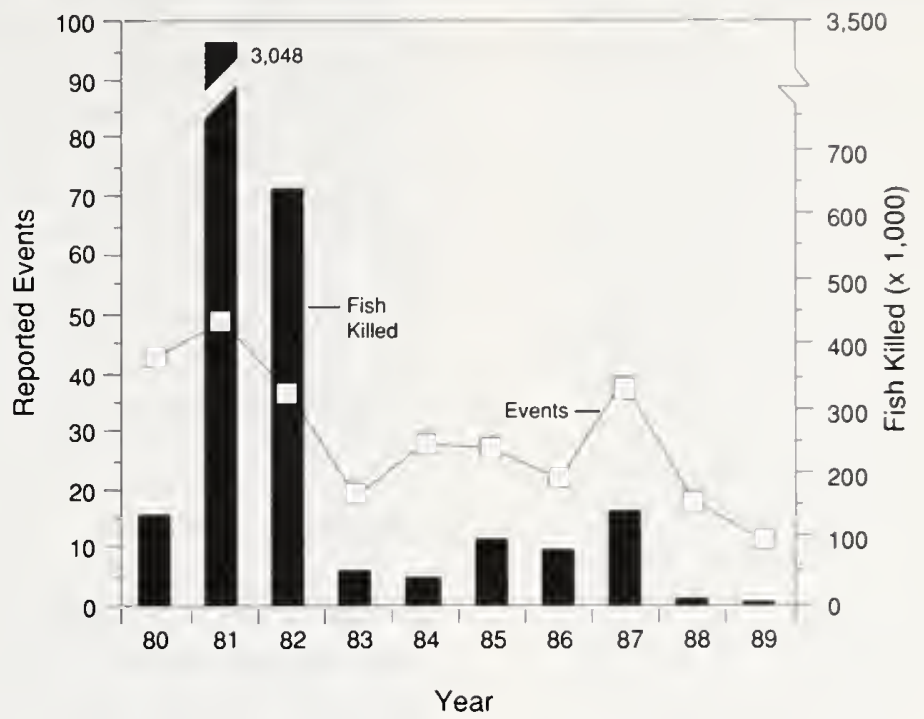

region, with over 3.3 million or 77 percent of all reported fish killed between 1980 and 1989 . Seventy-nine percent of these fish were killed in a single event that occurred in August 1981 in Cultus Bay, located in Island County. The event lasted for one day and was reported as a natural event that occurred in a poorly designed marina. The direct cause cited was low-dissolved oxygen.

Trends. The number of events reported from 1980 to 1989 shows a general downward trend (Figure 29). From 1980 to 1982 , at least 37 events occurred each year, with the

largest being 49 in 1981. However, from 1983 to 1989 , no more than 28 fish-kill events occurred in a single year (except in 1987 when 38 events were reported). In addition, an apparent seasonal pattern also exists in this region. Most events were reported between April and September (Figure 30). However, the greatest numbers of fish killed were reported in January, August, and September. A seasonal pattern exists across the Nation, with the majority of kills occurring during the summer months.

Figure 30. Number of Events and Fish Killed by Month, 1980-1989
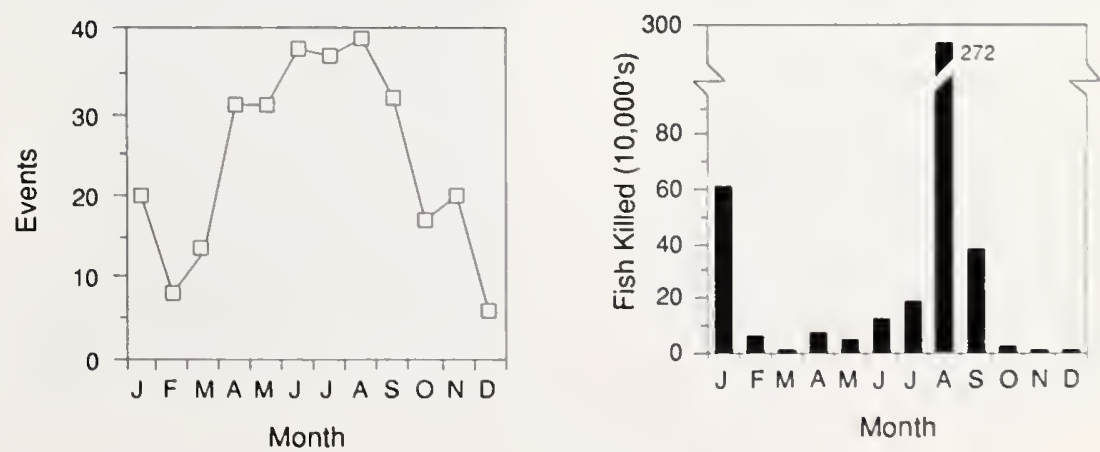


\section{Sources and Causes}

The Pacific region spans the widest geographic and climatic range of the five regions. In California, from San Francisco Bay south, the weather is generally warm and portions of the coast are densely populated. In this area, the prevalent direct cause of kills is lowdissolved oxygen and pesticides which occur in the agricultural drainage canals and freshwater reservoirs in the state. In contrast, Oregon and Washington tend to have more problems with spills and routine releases (e.g., chemicals from industrial plants in Oregon and animal wastes from dairy farms in Washington).

The top two direct causes of fish kills reported for the entire region were low-dissolved oxygen levels and pesticides (Figure 32). Kills related to impacts from human activities dominate the region, such as spills and routine or accidental releases occurring in agricultural, urban, and industrial land-use areas (Figures 31 and 33). In addition, almost a quarter of the events in the region is related to naturally occurring events (Figure 31).

In California, 110 of the 148 reported events indicated the direct cause of the kill. Lowdissolved oxygen was the direct cause reported in 25 of the 110 events. Forty-four of the 148 reported events indicated the land-use cause of the kill. Impoundments were the land-use cause in 13 of the 44 events. In only 44 of the 148 events was a land-use cause reported along with a direct cause.
In Oregon, 29 of the 40 reported events indicated the direct cause of the kill. An assortment of chemicals/metals (i.e., organic chemicals, inorganic chemicals/metals, and mixed chemicals) was the direct cause in 13 of the 29 events. Twenty-four of the 40 reported events indicated the land-use cause of the kill. Industrial land use was the land-use cause in 13 of the 24 events. A direct cause was associated with a land-use cause in 22 of the 40 reported events.

In Washington, 76 of the 105 reported events indicated the direct cause of the kill. Animal waste was the direct cause in 21 of the 76 events. Sixty-nine of the 105 reported events indicated the land-use cause of the kill. Agricultural land use was the land-use cause in 26 of the 69 events. In 64 of the 105 reported events, a direct cause was linked with a specific landuse cause.

Data tables containing the number of events and fish killed by county, state, region, year, direct cause, land-use cause, and incident are in Appendix A.

\section{Hotspots and Recurring Kills}

King County (39 events) in Washington and San Joaquin County (27 events) in California reported the highest number of fish-kill events in the region. The kills in King County were attributed to a variety of direct causes and land-use causes with no single type of event being dominant. However, the most frequently cited direct cause was chlorine that had been routinely released from an urban land-use area (e.g., water
Figure 31. Number of Fish-Kill Events by Type of Incident ${ }^{*}$



Figure 32. Number of Fish-Kill Events by Direct Cause*

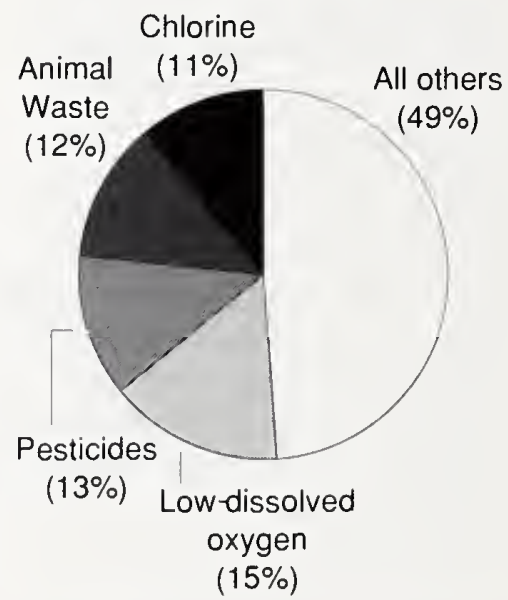

Figure 33. Number of Fish-Kill Events by Land-Use Cause*

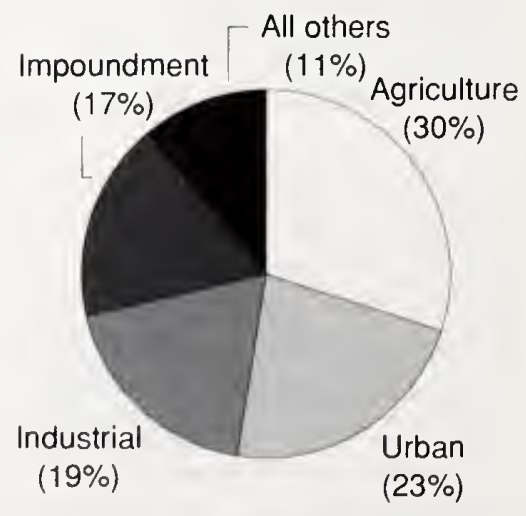

"Does not include information from unspecified events. 
treatment facility, construction site, water pipeline, and chlorinated wells). In contrast, the majority of the kills in San Joaquin County did not have a direct cause or an associated land-use cause. Eight of the 27 events reported low-dissolved oxygen levels as the direct cause of the event.

\section{Johnson Creek, located in} Oregon's Clackamas and Multnomah counties, was the waterbody for which the most events (9) were reported in this region. This creek is a tributary of the Willamette River.

Twenty-five percent of all the fish killed in Oregon were killed in this creek. The majority of the events cited the direct cause as a mixture of chemicals from unspecified sources. Whatcom Creek in Whatcom County, Washington, was another waterbody for which numerous events (5) were reported between 1981 and 1989. Most of the records for these events did not contain information on the associated land-use cause. However, pesticides were cited as the direct cause in three of the events.

\section{State Reporting Programs}

Each of the three Pacific states uses a different approach when collecting fish-kill data. The discussion below highlights which agencies in each state are involved in fish-kill reporting and when they are most likely to make an on-site investigation of a fish-kill event. Information concerning each state's program organization, investigative procedures, and use of data are summarized in Appen$\operatorname{dix} B$.
California has two divisions (Marine Resources and Inland Fisheries) under the Department of Fish and Game (DFG) that investigate and document fish kills. DFG's Environmental Services Division (the central clearinghouse for California's fish-kill records) provided fish-kill data for this report. The Environmental Services contact indicated that field visits are generally standard procedure when an event is reported.

Oregon has two agencies that may be involved in the fish-kill investigation process: the Department of Environmental Quality (DEQ) and the Department of Fish and Wildlife (DFW). The DEQ is specifically interested in kills caused by pollution, while the DFW responds to all kills. Both agencies provided fish-kill data for this report. Field visits are more likely to be made when a large number of fish is involved in a kill.

Washington's program is conducted by the Department of Ecology. It provided fish-kill data for this project and reported that field visits to fish-kill sites are made more than 75 percent of the time. 


\section{Concluding Comments}

Fish-kill reporting programs provide an incomplete picture of the Nation's fish-kill problems. Even so, they indicate that fish kills have not been a pervasive problem in the Nation's estuarine and coastal areas. Taken together, the data generated by these State and local programs also provide a basis for quantifying and understanding certain aspects of fish kills. Several conclusions regarding the uses and limitations of these data are important to note.

\section{Compiling State Data is}

Difficult. Although all 22 coastal states maintain some form of fish-kill reporting program, data compilation is difficult. Reporting responsibilities within most states are often shared by several agencies. Consequently, data are in varied formats and gaps occur in some states as a result of lapses in State programs or data lost during the transfer of program responsibilities. The analysis problem is further compounded because no Federal agency or national organization maintains a comprehensive and up-to-date data base for the Nation.

\section{Data Content Varies Among}

States. There is a wide variation in organization, level of activity, priorities, investigative procedures, documentation requirements, and reporting formats among states. As a result, the data content of the information characterizing fish kills varies from state to state. This lack of consistency in data content makes it difficult to reconcile differences in state-to-state and regional comparisons.

Little Evidence of Impacts on Fish Populations. Fish kills in coastal waters do not appear to occur with sufficient frequency or involve enough fish to pose a significant threat to fish populations in most areas. None of the State programs surveyed indicated population impacts resulting from fish kills. Even if the estimates reported are doubled to account for incomplete reporting, the number of fish killed is still relatively small compared to estimates of existing populations in most areas.

Assessing Trends is Difficult. Although the number of events in coastal areas has increased over the past decade, the number of fish killed has decreased. The cause of these apparent trends is not clear. The rise in the number of events may indicate a decline in water quality during this period, or reflect an increased emphasis on reporting. Because the data are incomplete and lack uniformity, conclusive statements at the national or regional level cannot be made. However, a recurring seasonal pattern appears in all states, indicating most events take place during the summer, from May to September.

\section{Hotspots Can Sometimes be}

Targeted. Fish-kill data are most frequently used by State agencies to identify areas experiencing acute environmental stress. Ideally, the agency uses the data to quickly determine the source of the stress and correct the problem. However, repeat kills may sometimes occur before action is taken. The fish kills in Mattanawcook Stream in Maine are a good example of how fish-kill data were used to identify and correct a discharge problem from a single source (page 11). In other cases, fish-kill events have lead to a more in-depth investigation of water-quality problems. The Pamlico Estuarine Response Team (PERT), formed in North Carolina, is an example of how fish-kill data have been used to target an area experiencing ongoing water-quality problems (page 21).

\section{Low-Dissolved Oxygen Causes Most Kills. Low-} dissolved oxygen was reported as the direct cause of a kill in 41 percent of the cases reporting cause. Although spills or accidental releases from point sources still occur, the majority of human-induced kills is now attributed to runoff from various nonpoint sources. Conversations with State fish-kill officials indicate that kills caused by pollutants from point sources (industries and wastewater treatment plants) have been reduced in the last 10 to 15 years due to improvements in treatment. They also noted a decrease in kills associated with compounds such as DDT and other chlorinated pesticides that are now used less frequently or are banned entirely. 

Bureau of the Census. 1988.

County and City Data Book

(1988). U.S. Department of

Commerce, Washington, D.C.

p. 68

Environmental Law Institute. 1988. Clean Water Deskbook. Washington, D.C. p. 77

Hinga, K.R., D.W. Stanley, C.J. Klein, D.T. Lucid, and M.J. Katz (eds). 1991. The National Estuarine Eutrophication Project: Workshop Proceedings. Rockville, MD: National Oceanic and Atmospheric Administration and the University of Rhode Island Graduate School of Oceanography. 41 pp.

NOAA. 1987. National Estuarine Inventory: Data Atlas, Volume 2: Land-Use Characteristics. Rockville, MD: National Oceanic and Atmospheric Administration. $40 \mathrm{pp}$.

NOAA. 1990. Estuaries of the United States: Vital Statistics of a National Resource Base. Strategic Assessment Branch, Rockville, MD. 79 pp.

Pait, A. S., A. DeSouza, and D.R.G. Farrow. 1991. Agricultural Pesticides in Coastal Areas: A National Summary. Rockville, MD: National Oceanic and Atmospheric Administration. (In preparation)

\section{Personal Communications}

\section{Federal Agencies}

Farrow, D.; Strategic Environmental Assessments Division, National Oceanic and Atmospheric Administration, Rockville, MD (p. 1, para 7)
Harllee, N.; Monitoring and Data Support Division; Office of Water Enforcement and Permits; U.S. Environmental Protection

Agency; Washington, D.C. (see Acknowledgements and EPA

Fish-Kill Data Base, p. 2)

\section{State Aqencies}

Alabama

Williford, E. J.; Alabama's Department of Environmental Management; Montgomery, AL. (p. 27)

$\underline{\text { California }}$

Fransen, H.R.; Environmental Services Division; California's Department of Fish and Game; Rancho Cordova, CA. (p. 31)

\section{$\underline{\text { Connecticut }}$}

Jacobson, R. A.; Water Management and Fisheries Division; Connecticut's Department of Environmental Protection; Hartford, CT. (p. 16)

\section{Delaware}

Miller, R. W.; Division of Fish and Wildlife; Delaware's Department of Natural Resources and Environmental Control; Dover, DE. (p. 16)

\section{Florida}

Champeau, T.; South Region, Florida's Game and Freshwater Fish Commission; Lakeland, FL. (p. 22)

Krummrich, J.; Northeast Region, Florida's Game and Freshwater Fish Commission; Lake City, FL. (p. 22)
McKinney, S.; Central Region, Florida's Game and Freshwater Fish Commission; Ocala, FL. (p. 22)

Morton, R. D.; Bioenvironmental Services Division, Duval County; Jacksonville, FL. ( $p$. 22)

Olsen, L. A.; Florida's Department of Environmental Regulation; Tallahassee, FL. (p. 22)

Romeis, G.; South District Office, Florida's Department of Environmental Regulation; Fort Myer, FL. (p. 22)

Ross, Landon; Florida's Department of Environmental Regulation; Tallahassee, FL. (see HotSpots and Recurring Kills, p. 22)

Walton, A. S.; South District Office; Florida's Department of Environmental Regulation; Punta Gorda, FL. (p. 22)

Young, N.; Northwest Region, Florida's Game and Freshwater Fish Commission; DeFuniak Springs, FL. (p. 22)

\section{Georgia}

Coomer, C. Jr.; Fisheries Section; Game and Fish Division; Georgia's Department of Natural Resources; Atlanta, GA. (p. 22)

Shipman, S.; Coastal Resources Division; Georgia's Department of Natural Resources; Brunswick, GA. (p. 22)

Louisiana

Albritton, R.; Louisiana's Department of Environmental Quality; Baton Rogue, LA. ( $p$. 27) 


\section{Maine}

Courtmanch, D.; Maine's Department of Environmental Protection; Augusta, ME. (see Maine, and Hot-Spots and Recurring Kills, p. 11)

\section{Maryland}

Poukish, C.; Water Quality Monitoring Division; Maryland's Department of the Environment; Annapolis, MD. (p. 16)

\section{Massachusetts}

Fiske, J. D.; Division of Marine Fisheries; Massachusetts' Department of Fisheries, Wildlife, and Environmental Law Enforcement; Sandwich, MA. (p. 11)

Keller, R.; Division of Fisheries and Wildlife; Massachusetts' Department of Fisheries, Wildlife, and Environmental Law Enforcement; Westboro, MA. (p. 11)

\section{Mississippi}

Rodgers, S.; Bureau of Pollution Control; Mississippi's Department of Environmental Quality; Pearl, MS. (p. 27)

\section{New Hampshire}

Ingham, W. Jr.; New Hampshire's Department of Fish and Game;

Durham, NH. (p. 11)

Nelson, J.; New Hampshire's Department of Fish and Game; Durham, NH. (p. 11)

\section{New Jersey}

Murza, S.; Bureau of Law Enforcement; Fish, Game, and Wildlife Division; New Jersey's Department of Environmental Protection; Trenton, NJ. (p. 16)
Winkel, R.; Bureau of Law Enforcement; Fish, Game, and Wildlife Division; New Jersey's Department of Environmental Protection; Trenton, NJ. (p. 16)

\section{New York}

Spodaryk, J.; New York's

Department of Environmental

Conservation; Gloversville, NY (p. 16)

\section{North Carolina}

Wiggins, K.; Division of Environmental Management; North Carolina's Department of Environment, Health, and Natural Resources; Raleigh, NC. (p. 21)

\section{Oregon}

Robart, G.; Oregon's Department of Fish and Wildlife;

Portland, OR. (p. 31)

\section{Pennsylvania}

Manhart, E. W.; Bureau of Law Enforcement; Pennsylvania's Fish Commission; Harrisburg, PA. (p. 16)

\section{Rhode Island}

Richardson, R. E.; Water Resources Division; Rhode Island's Department of Environmental Management; Providence, RI. (p. 15)

\section{South Carolina}

Adams, C.; Bureau of Solid and Hazardous Waste Management; South Carolina's Department of Health and Environmental Control; Columbia, SC. (p. 21)
Kinney, R.; Waste Assessment and Emergency Response; Bureau of Solid and Hazardous Waste Management; South Carolina's Department of Health and Environmental Control; Columbia, SC. (p. 21)

\section{$\underline{\text { Texas }}$}

Palafox, D.; Resource Protection Division; Texas Parks and Wildlife Department; Austin, TX. (p. 27)

Palma, V.; Resource Protection Division; Texas Parks and Wildlife Department; Austin, TX. (p. 27)

\section{$\underline{\text { Virginia }}$}

Sykes, M.A.; Pollution Remediation Program; Virginia Water Control Board; Richmond, VA (p. 16)

\section{Washington}

LeVander, L.; Northwest Regional Office; Washington's Department of Ecology; Redmond, WA. (p. 31)

Kittle, L.; Central Office; Washington's Department of Ecology; Olympia, WA. (p. 31) 
Appendix A - North Atlantic

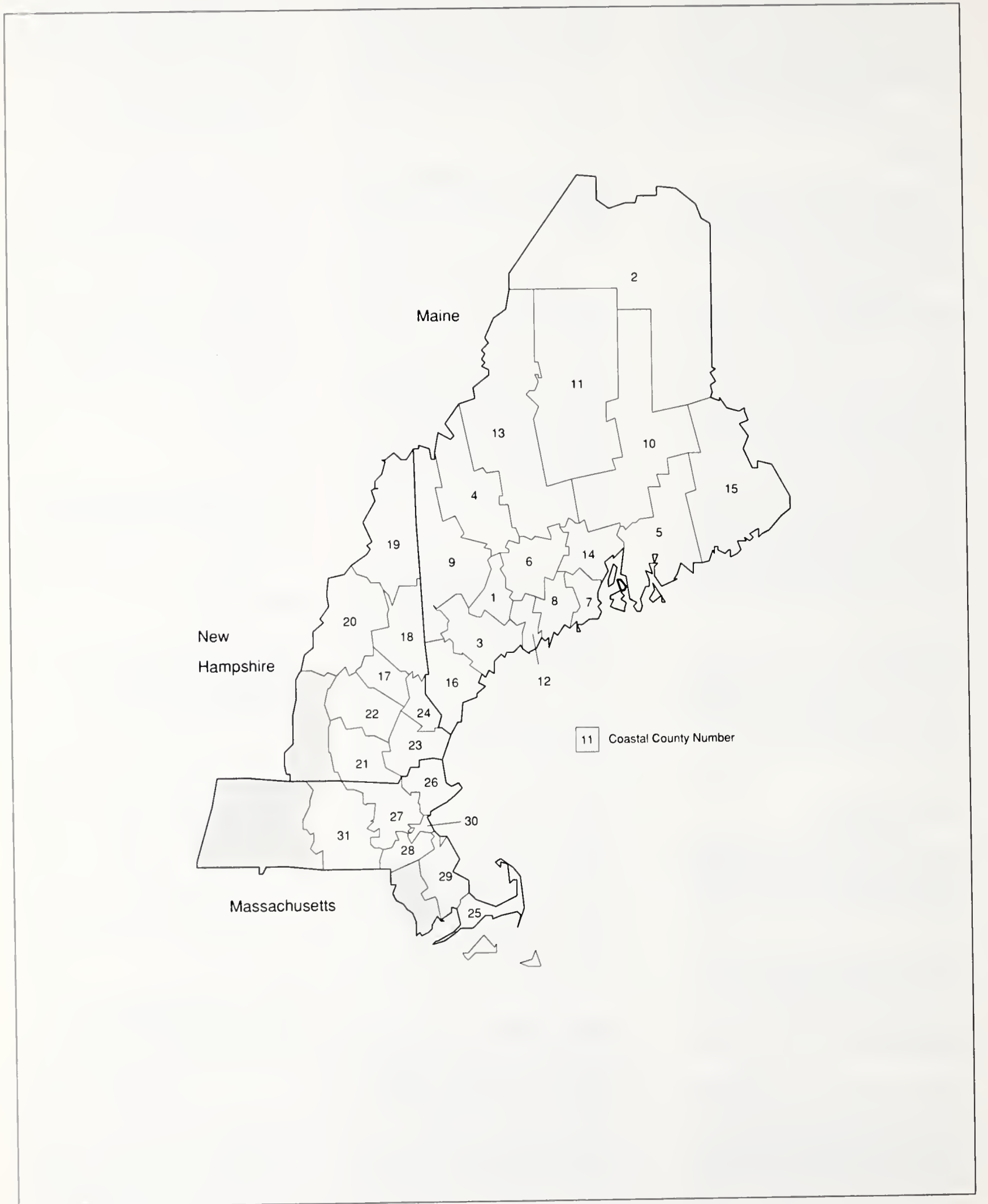


Fish-Kill Events by County, 1980-1989

\begin{tabular}{|c|c|c|c|c|c|}
\hline State/County & Events & $\begin{array}{l}\text { Killed } \\
(x 100)\end{array}$ & $\begin{array}{l}\% \text { of events } \\
\text { where \# killed } \\
\text { was reported }\end{array}$ & $\begin{array}{l}\% \text { of events } \\
\text { where cause } \\
\text { of kill was reported }\end{array}$ & $\begin{array}{l}\text { \# of events } \\
\text { where } 1 \text { million or } \\
\text { more fish were killed }\end{array}$ \\
\hline \multicolumn{6}{|l|}{ Maine } \\
\hline 1 Androscoggin & 3 & 80 & 100 & 100 & 0 \\
\hline 2 Aroostook & $N D$ & ND & ND & $N D$ & NO \\
\hline 3 Cumberland & 1 & 2 & 100 & 100 & 0 \\
\hline 4 Franklin & 1 & 1 & 100 & 100 & 0 \\
\hline 5 Hancock & $N D$ & $N D$ & $N D$ & ND & $N D$ \\
\hline 6 Kennebec & $N D$ & $N D$ & $N D$ & ND & $N D$ \\
\hline 7 Knox & ND & ND & $N D$ & $N D$ & $N D$ \\
\hline 8 Lincoln & ND & ND & ND & ND & ND \\
\hline 9 Oxford & 2 & 1,005 & 50 & 100 & 0 \\
\hline 10 Penobscot & 13 & 31 & 92 & 100 & 0 \\
\hline 11 Piscataquis & ND & $N D$ & $N D$ & $N D$ & ND \\
\hline 12 Sagadahoc & 3 & 460 & 100 & 100 & 0 \\
\hline 13 Somerset & 2 & 4 & 100 & 100 & 0 \\
\hline 14 Waldo & ND & ND & ND & ND & ND \\
\hline 15 Washington & 2 & 45 & 100 & 100 & 0 \\
\hline 16 York & 1 & $N R$ & 0 & 100 & 0 \\
\hline Subtotal & 28 & 1,628 & 90 & 100 & 0 \\
\hline \multicolumn{6}{|l|}{ New Hampshire } \\
\hline 17 Belknap & 1 & 1 & 100 & 100 & 0 \\
\hline 18 Carroll & ND & ND & $N D$ & $N D$ & ND \\
\hline 19 Coos & $N D$ & $N D$ & $N D$ & $N D$ & $N D$ \\
\hline 20 Grafton & ND & $N D$ & ND & ND & ND \\
\hline 21 Hillsborough & $N D$ & $N D$ & ND & $N D$ & ND \\
\hline 22 Merrimack & $N D$ & $N D$ & $N D$ & $N D$ & $N D$ \\
\hline 23 Rockingham & $N D$ & $N D$ & ND & $N D$ & $N D$ \\
\hline 24 Strafford & ND & ND & ND & ND & $N D$ \\
\hline Subtotal & 1 & 1 & 100 & 100 & 0 \\
\hline \multicolumn{6}{|l|}{ Massachusetts } \\
\hline 25 Barnstable & 10 & 39,207 & 90 & 70 & 1 \\
\hline 26 Essex & ND & ND & ND & $N D$ & ND \\
\hline 27 Middlesex & 2 & 4 & 100 & 50 & 0 \\
\hline 28 Norfolk & 3 & 23 & 100 & 67 & 0 \\
\hline 29 Plymouth & 3 & 34 & 100 & 67 & 0 \\
\hline 30 Suffolk & $N D$ & $N D$ & $N D$ & ND & ND \\
\hline 31 Worcester & 1 & 6 & 100 & 0 & 0 \\
\hline Subtotal & 19 & 39,273 & 95 & 51 & 1 \\
\hline Total & 48 & 40,903 & 92 & 84 & 1 \\
\hline National Total & 3,654 & $4,071,630$ & 84 & 79 & 86 \\
\hline
\end{tabular}

Abbreviations: \%, percent; \#, number; NR, number of fish killed not reported; $N D$, no data was received. 
Appendix A

Fish-Kill Events by Year, 1980-1989

\begin{tabular}{|c|c|c|c|c|c|c|c|c|}
\hline \multirow[b]{2}{*}{ Year } & \multicolumn{2}{|c|}{ Maine } & \multicolumn{2}{|c|}{$\begin{array}{c}\text { New } \\
\text { Hampshire }\end{array}$} & \multicolumn{2}{|c|}{ Massachusetts ${ }^{a}$} & \multicolumn{2}{|c|}{ Total } \\
\hline & $e$ & $k$ & $e$ & $k$ & $e$ & $k$ & $e$ & $k$ \\
\hline 1980 & 2 & 1,030 & 1 & 1 & 2 & 19 & 5 & 1,050 \\
\hline 1981 & 1 & 20 & 0 & 0 & 4 & 39 & 5 & 59 \\
\hline 1982 & 2 & 6 & 0 & 0 & 0 & 0 & 2 & 6 \\
\hline 1983 & 6 & 76 & 0 & 0 & 1 & 39,119 & 7 & 39,195 \\
\hline 1984 & 2 & 310 & 0 & 0 & 1 & 3 & 3 & 313 \\
\hline 1985 & 3 & 107 & 0 & 0 & 5 & 82 & 8 & 189 \\
\hline 1986 & 3 & 12 & 0 & 0 & 0 & 0 & 3 & 12 \\
\hline 1987 & 2 & 2 & 0 & 0 & 2 & 2 & 4 & 4 \\
\hline 1988 & 6 & 62 & 0 & 0 & 2 & 2 & 8 & 64 \\
\hline 1989 & 1 & 3 & 0 & 0 & 2 & 8 & 3 & 10 \\
\hline Total & 28 . & 1,628 & 1 & 1 & 19 & 39,273 & 48 & 40,903 \\
\hline
\end{tabular}

Fish-Kill Events by Direct Cause, 1980-1989

\begin{tabular}{|c|c|c|c|c|c|c|c|c|}
\hline \multirow[b]{2}{*}{ Direct Cause } & \multicolumn{2}{|c|}{ Maine } & \multicolumn{2}{|c|}{$\begin{array}{c}\text { New } \\
\text { Hampshire }\end{array}$} & \multicolumn{2}{|c|}{ Massachusetts $^{2}$} & \multicolumn{2}{|c|}{ Total } \\
\hline & $e$ & $k$ & $e$ & $k$ & $e$ & $k$ & $e$ & $k$ \\
\hline Low D. O. & 5 & 488 & 0 & 0 & 4 & 39,126 & 9 & 39,614 \\
\hline Temperature & 1 & 2 & 0 & 0 & 1 & 3 & 2 & 5 \\
\hline Sedimentation & 0 & 0 & 0 & 0 & 0 & 0 & 0 & 0 \\
\hline Eutrophication & 0 & 0 & 0 & 0 & 0 & 0 & 0 & 0 \\
\hline Disease & 0 & 0 & 0 & 0 & 1 & 1 & 1 & 1 \\
\hline Stranding & 2 & 6 & 0 & 0 & 1 & 3 & 3 & 9 \\
\hline Storm Event & 1 & $N R$ & 0 & 0 & 0 & 0 & 1 & NR \\
\hline Wastewater & 9 & 1,019 & 0 & 0 & 3 & 17 & 12 & 1,036 \\
\hline Animal Waste & 0 & 0 & 0 & 0 & 0 & 0 & 0 & 0 \\
\hline $\mathrm{pH}$ & 4 & 6 & 0 & 0 & 0 & 0 & 4 & 6 \\
\hline Organic Chemicals & 2 & 21 & 0 & 0 & 0 & 0 & 2 & 21 \\
\hline Inorganic Chemicals/Metals & 2 & 70 & 1 & 1 & 0 & 0 & 3 & 71 \\
\hline Mixed Chemicals & 1 & 7 & 0 & 0 & 0 & 0 & 1 & 7 \\
\hline Pesticides & 0 & 0 & 0 & 0 & 2 & 45 & 2 & 45 \\
\hline Nutrients & 0 & 0 & 0 & 0 & 0 & 0 & 0 & 0 \\
\hline Salinity Changes & 0 & 0 & 0 & 0 & 0 & 0 & 0 & 0 \\
\hline Petroleum & 1 & 10 & 0 & 0 & 0 & 0 & 1 & 10 \\
\hline Chlorine & 0 & 0 & 0 & 0 & 0 & 0 & 0 & 0 \\
\hline Red Tide & 0 & 0 & 0 & 0 & 0 & 0 & 0 & 0 \\
\hline Predation & 0 & 0 & 0 & 0 & 0 & 0 & 0 & 0 \\
\hline Unspecified & 0 & 0 & 0 & 0 & 7 & 79 & 7 & 79 \\
\hline Total & 28 & 1,628 & 1 & 1 & 19 & 39,273 & 48 & 40,903 \\
\hline
\end{tabular}

Abbreviations: $\boldsymbol{e}$ number of events; $\boldsymbol{k}$, number of fish killed in hundreds of fish; NR, number of fish killed not reported; Low D.O., low-dissolved oxygen. a. Not all counties in state included; state is splıt between regions. 
Fish-Kill Events by Land-Use Cause, 1980-1989

\begin{tabular}{lrrrrrrrr} 
& \multicolumn{2}{c}{ Maine } & \multicolumn{2}{c}{$\begin{array}{c}\text { New } \\
\text { Hampshire }\end{array}$} & \multicolumn{2}{c}{ Massachusetts } & \multicolumn{2}{c}{ Total $^{\text {a }}$} \\
Land-Use Cause & $\boldsymbol{e}$ & $\boldsymbol{k}$ & $\boldsymbol{k}$ & $\boldsymbol{k}$ & $\boldsymbol{e}$ & $\boldsymbol{k}$ & $\boldsymbol{e}$ & $\boldsymbol{k}$ \\
\hline Agriculture & 1 & $N R$ & 0 & 0 & 6 & 79 & 7 & 79 \\
Industrial & 19 & 1,147 & 0 & 0 & 0 & 0 & 19 & 1,147 \\
Urban & 1 & 5 & 1 & 1 & 1 & 3 & 3 & 9 \\
Impoundment & 1 & 1 & 0 & 0 & 0 & 0 & 1 & 1 \\
Water-Related & 3 & 460 & 0 & 0 & 4 & 8 & 7 & 468 \\
Silviculture & 0 & 0 & 0 & 0 & 0 & 0 & 0 & 0 \\
Wildland & 0 & 0 & 0 & 0 & 0 & 0 & 0 & 0 \\
Mining & 0 & 0 & 0 & 0 & 0 & 0 & 0 & 0 \\
Military & 0 & 0 & 0 & 0 & 0 & 0 & 0 & 0 \\
Unspecified & 3 & 15 & 0 & 0 & 8 & 39,183 & 11 & 39,198 \\
Total & $\mathbf{2 8}$ & $\mathbf{1 , 6 2 8}$ & $\mathbf{1}$ & $\mathbf{1}$ & 19 & 39,273 & $\mathbf{4 8}$ & $\mathbf{4 0 , 9 0 3}$ \\
\hline
\end{tabular}

Fish-Kill Events by Incident, 1980-1989

\begin{tabular}{|c|c|c|c|c|c|c|c|c|}
\hline \multirow[b]{2}{*}{ Incident } & \multicolumn{2}{|c|}{ Maine } & \multicolumn{2}{|c|}{$\begin{array}{c}\text { New } \\
\text { Hampshire }\end{array}$} & \multicolumn{2}{|c|}{ Massachusetts ${ }^{a}$} & \multicolumn{2}{|c|}{ Total } \\
\hline & $e$ & $k$ & $e$ & $k$ & $e$ & $k$ & $e$ & $k$ \\
\hline Runoff & 1 & $N R$ & 1 & 1 & 1 & 30 & 3 & 31 \\
\hline Routine Release & 9 & 1,021 & 0 & 0 & 2 & 4 & 11 & 1,025 \\
\hline Accidental Release & 1 & $N R$ & 0 & 0 & 0 & 0 & 1 & $N R$ \\
\hline Spill & 3 & 32 & 0 & 0 & 1 & 13 & 4 & 45 \\
\hline Spraying & 0 & 0 & 0 & 0 & 1 & 15 & 1 & 15 \\
\hline Natural & 3 & 460 & 0 & 0 & 5 & 39,127 & 8 & 39,587 \\
\hline Drawdown & 3 & 9 & 0 & 0 & 1 & 3 & 4 & 12 \\
\hline Dredging or Drilling & 0 & 0 & 0 & 0 & 0 & 0 & 0 & 0 \\
\hline Unspecified & 8 & 107 & 0 & 0 & 8 & 82 & 16 & 189 \\
\hline Total & 28 & 1,628 & 1 & 1 & 19 & 39,273 & 48 & 40,903 \\
\hline
\end{tabular}

Abbreviations: $e$ number of events; $k$, number of fish killed in hundreds of fish; NR, number of fish killed not reported.

a. Not all counties in state included; state is split between regions. 


\section{Appendix A - Middle Atlantic}

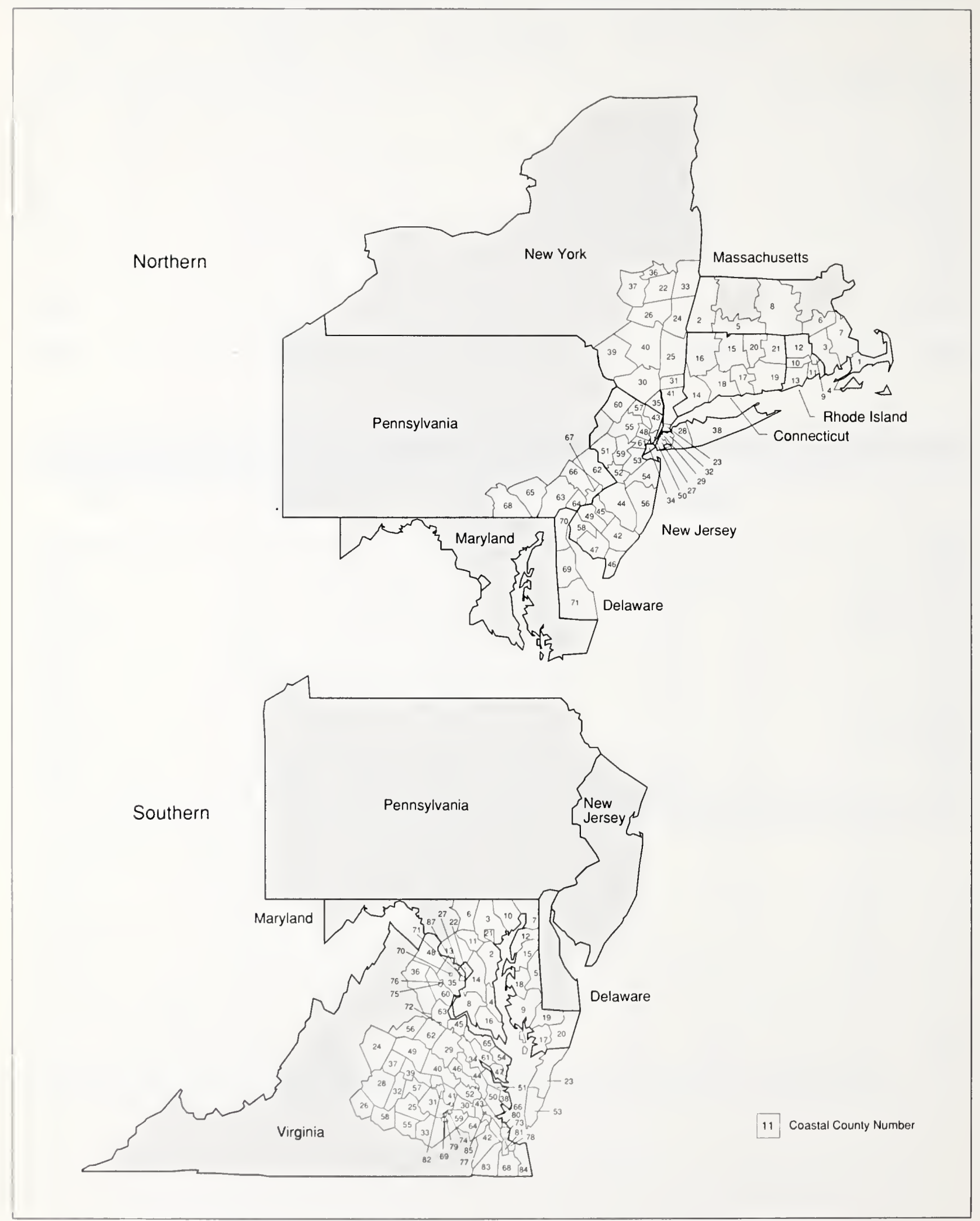


Fish-Kill Events by County, 1980-1989

\begin{tabular}{llll}
\hline State/County & Killed & $\begin{array}{c}\% \text { of events } \\
\text { where \# kllled } \\
\text { was reported }\end{array}$ & $\begin{array}{c}\text { \% of events } \\
\text { where cause of events } \\
\text { of klll was reported more flsh were kllled }\end{array}$ \\
\hline
\end{tabular}

Middle Atlantic (Northern)

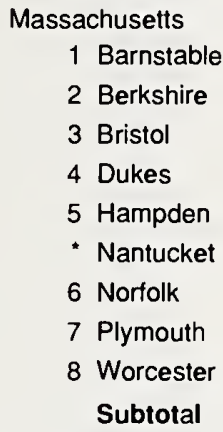

Data found in the North Allantic region.

$\begin{array}{rr}1 & <1 \\ 5 & 232 \\ N D & N D \\ 2 & 126 \\ N D & N D\end{array}$

Data found in the North Atlantic region. Data found in the North Atlantic region. Data found in the North Atlantic region.

$$
8
$$

358

63

Rhode Island
9 Bristol
10 Kent
11 Newport
12 Providence
13 Washington
Subtotal

Connecticut
14 Fairfield
15 Hartford
16 Litchfield
17 Middlesex
18 New Haven
19 New London
20 Tolland
21 Windham
Subtotal

New York

22 Albany
23 Bronx
24 Columbia
25 Dutchess
26 Greene
27 Kings
28 Nassau
29 New York
30 Orange
31 Putnam
32 Queens
33 Rensselaer
34 Richmond
35 Rockland
36 Schenectady

ND

6

2

7

3

18

8
11
4
8
9
11
2
2
55

1,337

23

27

161

1,100

143

2

1

2,794

549
20,000
229
11
45
$N D$
$N R$
$N D$
208
59
20
11,635
100
30
$N D$

100

100

100

ND

100

ND

ND

100

50

71

100

83

88
82
100
100
100
91
100
100
93

93

75

100

73

100

73

ND

0

ND

93

100

100

76

100

78

ND
0
60
$N D$
100
$N D$

0
0
$N D$
0
$N D$

ND

0

.

\section{0}

$\begin{array}{lr}N D & N D \\ 83 & 0 \\ 50 & 0 \\ 71 & 0 \\ 67 & 0 \\ 72 & 0\end{array}$

$\begin{array}{rl}75 & 0 \\ 82 & 0 \\ 75 & 0 \\ 63 & 0 \\ 78 & 0 \\ 73 & 0 \\ 100 & 0 \\ 100 & 0 \\ 76 & 0 \\ & 0\end{array}$

Abbreviations: \%, percent; \#, number; NR, number of fish killed not reported; ND, no data was received.

"Not shown on map. 
Fish-Kill Events by County, 1980-1989

\begin{tabular}{cccc}
\hline & Killed & $\begin{array}{c}\% \text { of events } \\
\text { where \# killed } \\
\text { was reported }\end{array}$ & $\begin{array}{c}\% \text { of events of ents } \\
\text { where cause } \\
\text { of kill was reported more fish were killed }\end{array}$ \\
State County & Events & $(x 100)$ & mhere 1 million or
\end{tabular}

Middle Allantic (Northern)

New York (cont.)
37 Schoharie
38 Suffolk
39 Sullivan
40 Uister
41 Westchester
Subtotal

New Jersey

42 Atlantic

43 Bergen

44 Burlington

45 Camden

46 Cape May

47 Cumberland

48 Essex

49 Gloucester

50 Hudson

51 Hunterdon

52 Mercer

53 Middlesex

54 Monmouth

55 Morris

56 Ocean

57 Passaic

58 Salem

59 Somerset

60 Sussex

61 Union

Subtotal

Pennsylvania

62 Bucks
63 Chester
64 Delaware
65 Lancaster
66 Montgomery
67 Philadelphia
68 York
Subtotal

Delaware
69 Kent
70 New Castle
71 Sussex
Subtotal

1

7

ND

14

17

151

$(x 100)$

was reported

$\begin{array}{rrr}<1 & 100 & 100 \\ 38 & 100 & 57 \\ N D & N D & N D \\ 136 & 100 & 79 \\ 82 & 94 & 82 \\ 33,142 & 88 & 77\end{array}$

100
57
ND
79
82
77

0

57

ND ND

990

3

ND ND ND

$\begin{array}{lll}N R & 0 & 80\end{array}$

$\begin{array}{lll}N R & 0 & 75\end{array}$

$\begin{array}{lll}N R & 0 & 67\end{array}$

ND ND ND

NR $\quad 0 \quad 0$

$<1 \quad 33 \quad 33$

NR

NR

NR

2

101

NR

$<1$

NR

NR

NR

NR

NR

NA

103

33
67

0

67

33

73

46

55

50

50

60

44

0

100

57

ND

0

0

0

ND

0

0

0

0

0

0

0

0

0

0

0

0

0

0

0

112

$$
4
$$

0

$22 \quad 100$

$144 \quad 100$

$67 \quad 0$

750

$67 \quad 0$

ND ND

ND ND

$<1 \quad 100$

$5 \quad 100$

ND ND

$207 \quad 94$

0

0

ND

63

0

0

ND

$16 \quad 207$

$\begin{array}{rr}236,781 & 98 \\ 396 & 10 \\ 43,056 & 97 \\ 280,233 & 98\end{array}$

98
100
97
98

53

3

54

70

58

Abbreviations \%, percent, \#, number, NR, number of fish killed not reported, ND, no data was received. 
Fish-Kill Events by County,1980-1989

\begin{tabular}{|c|c|c|c|c|c|c|}
\hline \multicolumn{2}{|c|}{ State/County } & Events & $\begin{array}{l}\text { Killed } \\
(x 100)\end{array}$ & $\begin{array}{l}\% \text { of events } \\
\text { where \# killed } \\
\text { was reported }\end{array}$ & $\begin{array}{c}\% \text { of events } \\
\text { where cause } \\
\text { of kill was reported }\end{array}$ & $\begin{array}{c}\text { \# of events } \\
\text { where } 1 \text { million or } \\
\text { more fish were killed }\end{array}$ \\
\hline \multicolumn{7}{|c|}{ Middle Atlantic (Southern) } \\
\hline \multicolumn{7}{|c|}{ Maryland } \\
\hline & Anne Arundel & 182 & 359,847 & 66 & 82 & 8 \\
\hline & Baltimore & 47 & 14,340 & 91 & 60 & 1 \\
\hline & Calvert & 17 & 27,715 & 88 & 76 & 1 \\
\hline 5 & Caroline & 3 & 11 & 100 & 33 & 0 \\
\hline & Carroll & 7 & 30 & 100 & 71 & 0 \\
\hline 7 & Cecil & 18 & 231 & 67 & 33 & 0 \\
\hline & Charles & 14 & 10,061 & 86 & 36 & 1 \\
\hline & Dorchester & 15 & 18,852 & 73 & 93 & 1 \\
\hline 10 & Harford & 21 & 1,382 & 76 & 90 & 0 \\
\hline 11 & Howard & 4 & 6 & 75 & 75 & 0 \\
\hline 12 & Kent & 7 & 1,522 & 71 & 57 & 0 \\
\hline 13 & Montgomery & 4 & 7 & 75 & 50 & 0 \\
\hline 14 & Prince George's & 9 & 222 & 67 & 33 & 0 \\
\hline 15 & Queen Anne's & 14 & 111 & 71 & 64 & 0 \\
\hline 16 & St. Mary's & 28 & 23,727 & 86 & 82 & 2 \\
\hline 17 & Somerset & 7 & 39 & 86 & 43 & 0 \\
\hline 18 & Talbot & 14 & 17,674 & 93 & 86 & 1 \\
\hline 19 & Wicomico & 13 & 203,252 & 85 & 77 & 5 \\
\hline 20 & Worcester & 1 & 100 & 100 & 100 & 0 \\
\hline 21 & Baltimore City & 23 & 179 & 65 & 78 & 0 \\
\hline \multirow[t]{2}{*}{22} & District of Columbia & 7 & 5,520 & 71 & 71 & 0 \\
\hline & Subtotal & 455 & 684,828 & 75 & 73 & 20 \\
\hline \multicolumn{7}{|l|}{ Virginia } \\
\hline 23 & Accomack & 2 & 2 & 50 & 0 & 0 \\
\hline 24 & Albemarle & ND & $N D$ & ND & ND & ND \\
\hline 25 & Amelia & $N D$ & $N D$ & $N D$ & ND & ND \\
\hline 26 & Appomattox & 1 & $N R$ & 0 & 0 & 0 \\
\hline 27 & Arlington & 3 & 15 & 100 & 67 & 0 \\
\hline 28 & Buckingham & $N D$ & $N D$ & $N D$ & ND & ND \\
\hline 29 & Caroline & 2 & 428 & 100 & 100 & 0 \\
\hline 30 & Charles City & 1 & 1 & 100 & 0 & 0 \\
\hline 31 & Chesterfield & 5 & 42 & 100 & 60 & 0 \\
\hline 32 & Cumberland & $N D$ & $N D$ & ND & ND & ND \\
\hline 33 & Dinwiddie & $N D$ & $N D$ & $N D$ & $N D$ & ND \\
\hline 34 & Essex & ND & ND & ND & ND & $N D$ \\
\hline 35 & Fairfax & 8 & 48 & 100 & 88 & 0 \\
\hline 36 & Fauquier & 2 & $<1$ & 50 & 50 & 0 \\
\hline 37 & Fluvanna & 1 & $<1$ & 100 & 100 & 0 \\
\hline 38 & Gloucester & 1 & 1,000 & 100 & 0 & 0 \\
\hline 39 & Goochland & ND & $N D$ & ND & ND & ND \\
\hline 40 & Hanover & $N D$ & $N D$ & $N D$ & $N D$ & ND \\
\hline 411 & Henrico & 5 & 24 & 100 & 100 & 0 \\
\hline 42 & Isle of Wight & ND & ND & ND & ND & $N D$ \\
\hline 43 & James City & 2 & 60 & 100 & 100 & 0 \\
\hline 44 & King and Oueen & ND & ND & ND & ND & ND \\
\hline
\end{tabular}

Abbreviations: NR, number of fish killed not reported: $N D$, no data was received. 
Fish-Kill Events by County,1980-1989

\begin{tabular}{|c|c|c|c|c|c|}
\hline State County & Events & $\begin{array}{l}\text { KIIled } \\
(\times 100)\end{array}$ & $\begin{array}{l}\% \text { of events } \\
\text { where \# kllled } \\
\text { was reported }\end{array}$ & $\begin{array}{c}\% \text { of events } \\
\text { where cause } \\
\text { of kIll was reported }\end{array}$ & $\begin{array}{c}\text { \# of events } \\
\text { where } 1 \text { million or } \\
\text { more flsh were kllled }\end{array}$ \\
\hline \multicolumn{6}{|l|}{ Middle Atlantic (Southern) } \\
\hline \multicolumn{6}{|l|}{ Vırgınia (cont.) } \\
\hline 45 King George & ND & ND & ND & ND & $N D$ \\
\hline 46 King William & ND & $N D$ & ND & ND & ND \\
\hline 47 Lancaster & 3 & 126,400 & 67 & 0 & 2 \\
\hline 48 Loudoun & 1 & 2 & 100 & 100 & 0 \\
\hline 49 Louisa & 1 & 1 & 100 & 100 & 0 \\
\hline 50 Mathews & 1 & 4 & 100 & 0 & 0 \\
\hline 51 Middlesex & 2 & 20 & 50 & 0 & 0 \\
\hline 52 New Kent & 1 & $<1$ & 100 & 0 & 0 \\
\hline 53 Northampton & ND & $N D$ & ND & ND & ND \\
\hline 54 Northumberland & 4 & 11,052 & 100 & 50 & 1 \\
\hline 55 Nottoway & ND & $N D$ & ND & ND & ND \\
\hline 56 Orange & ND & $N D$ & ND & ND & ND \\
\hline 57 Powhatan & ND & ND & ND & ND & ND \\
\hline 58 Prince Edward & ND & ND & ND & ND & $N D$ \\
\hline 59 Prince George & 3 & 20 & 100 & 67 & 0 \\
\hline 60 Prince William & 4 & 46 & 100 & 100 & 0 \\
\hline 61 Richmond & 2 & 23 & 100 & 50 & 0 \\
\hline 62 Spotsylvania & ND & ND & ND & ND & ND \\
\hline 63 Stafford & 2 & 1 & 100 & 50 & 0 \\
\hline 64 Surry & ND & ND & ND & ND & ND \\
\hline 65 Westmoreland & 4 & 70 & 75 & 25 & 0 \\
\hline 66 York & 3 & 10,015 & 100 & 33 & 1 \\
\hline \multicolumn{6}{|c|}{ Virginia (Independent Cities) } \\
\hline 67 Alexandria & 3 & 21 & 100 & 33 & 0 \\
\hline 68 Chesapeake & \multicolumn{5}{|c|}{ Data found in the South Allantic region. } \\
\hline 69 Colonial Heights & 1 & 1,503 & 100 & 100 & 0 \\
\hline 70 Fairfax & ND & ND & ND & ND & ND \\
\hline 71 Falls Church & ND & ND & $N D$ & ND & ND \\
\hline 72 Frederıcksburg & ND & ND & ND & ND & ND \\
\hline 73 Hampton & 2 & 22 & 100 & 50 & 0 \\
\hline 74 Hopewell & 8 & 201 & 88 & 75 & 0 \\
\hline 75 Manassas & ND & $N D$ & $N D$ & $N D$ & ND \\
\hline 76 Manassas Park & $N D$ & ND & ND & ND & ND \\
\hline 77 Newport News & 2 & 22 & 100 & 50 & 0 \\
\hline 78 Norfolk & 6 & 35 & 100 & 83 & 0 \\
\hline 79 Petersburg & 2 & $<1$ & 50 & 50 & 0 \\
\hline 80 Poquoson & 2 & 503 & 100 & 50 & 0 \\
\hline 81 Portsmouth & 5 & 8 & 80 & 80 & 0 \\
\hline 82 Richmond & 3 & $N R$ & 0 & 67 & 0 \\
\hline - Southampion & \multicolumn{5}{|c|}{ Data found in the South Atlantic region. } \\
\hline 83 Suffolk & \multicolumn{5}{|c|}{ Data found in the South Atlantic region. } \\
\hline 84 Vırgınıa Beach & \multicolumn{5}{|c|}{ Data lound in the South Allantic region. } \\
\hline \multirow{2}{*}{$\begin{array}{l}85 \text { Williamsburg } \\
\text { Subtotal }\end{array}$} & ND & ND & ND & ND & ND \\
\hline & 98 & 151,591 & 88 & 61 & 4 \\
\hline Middle AtlanticTotal & 1,033 & $1,153,392$ & 65 & $\begin{array}{l}69 \\
79\end{array}$ & $\begin{array}{l}33 \\
86\end{array}$ \\
\hline National Total & 3,654 & $4,071,630$ & 84 & & 86 \\
\hline
\end{tabular}

Abbreviations NR. number of fish killed not reported: ND. no data was received.

- Not shown on map 


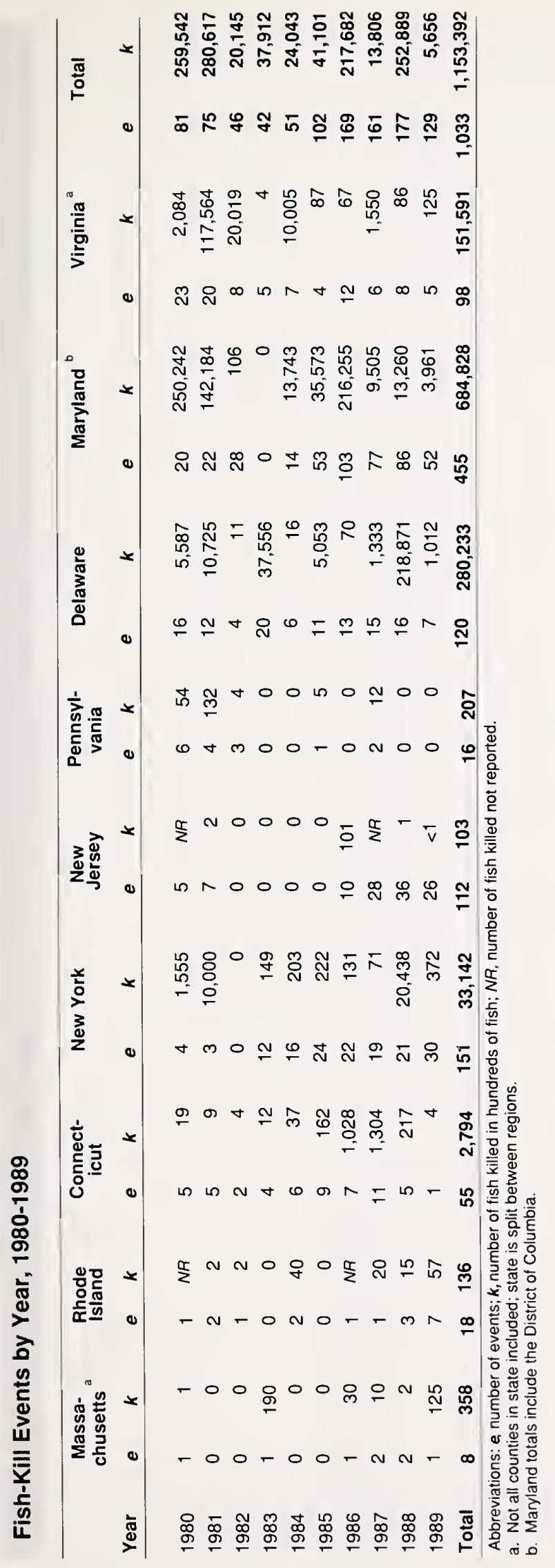




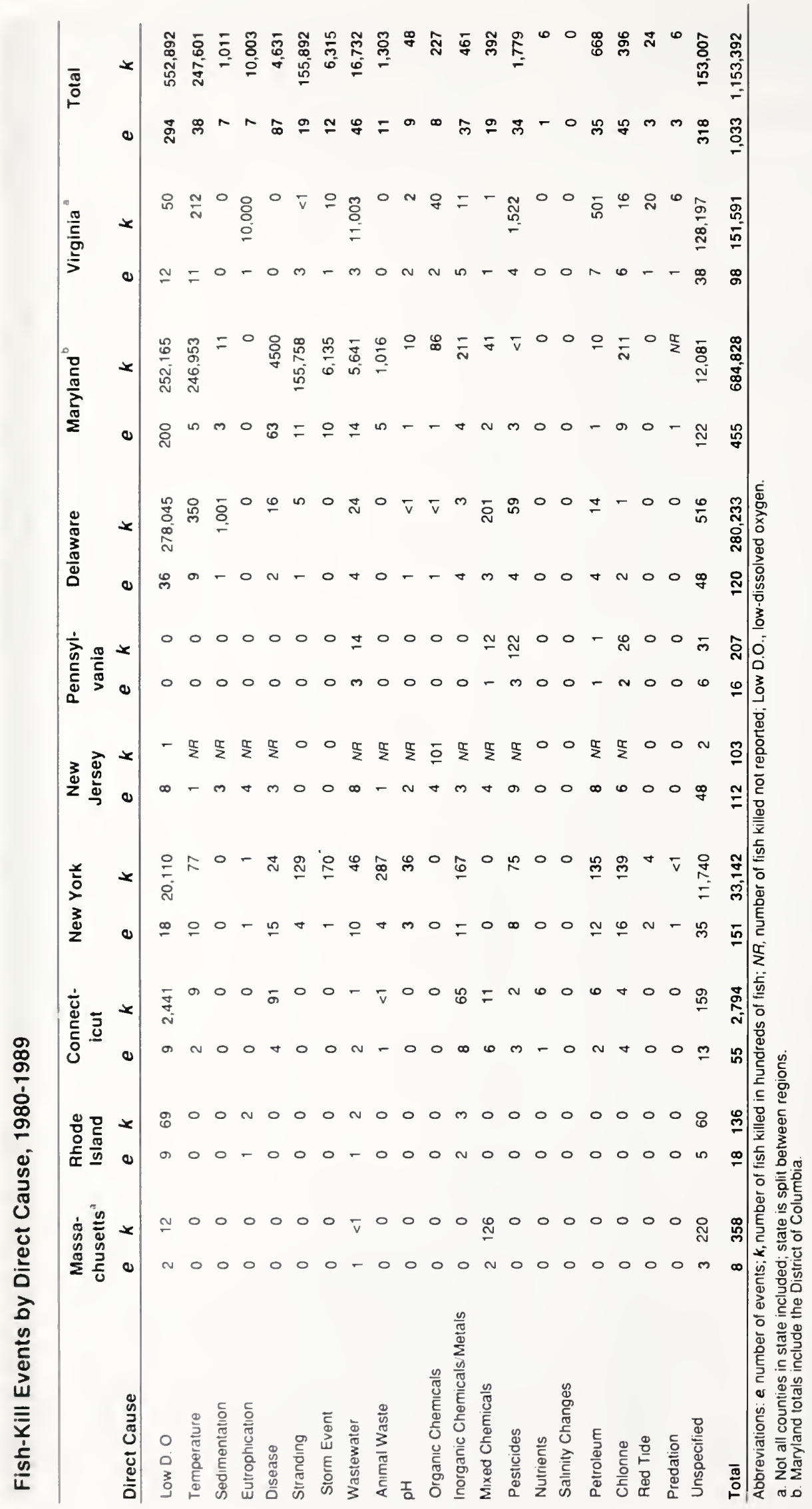




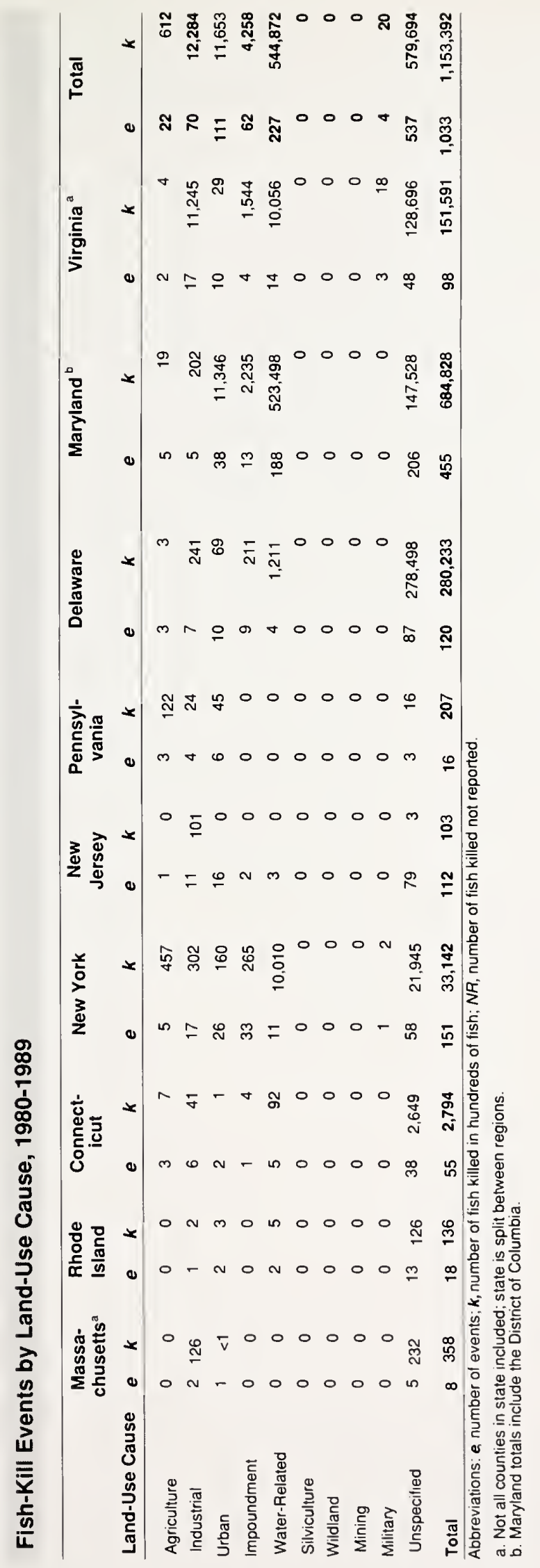




\section{Appendix A}

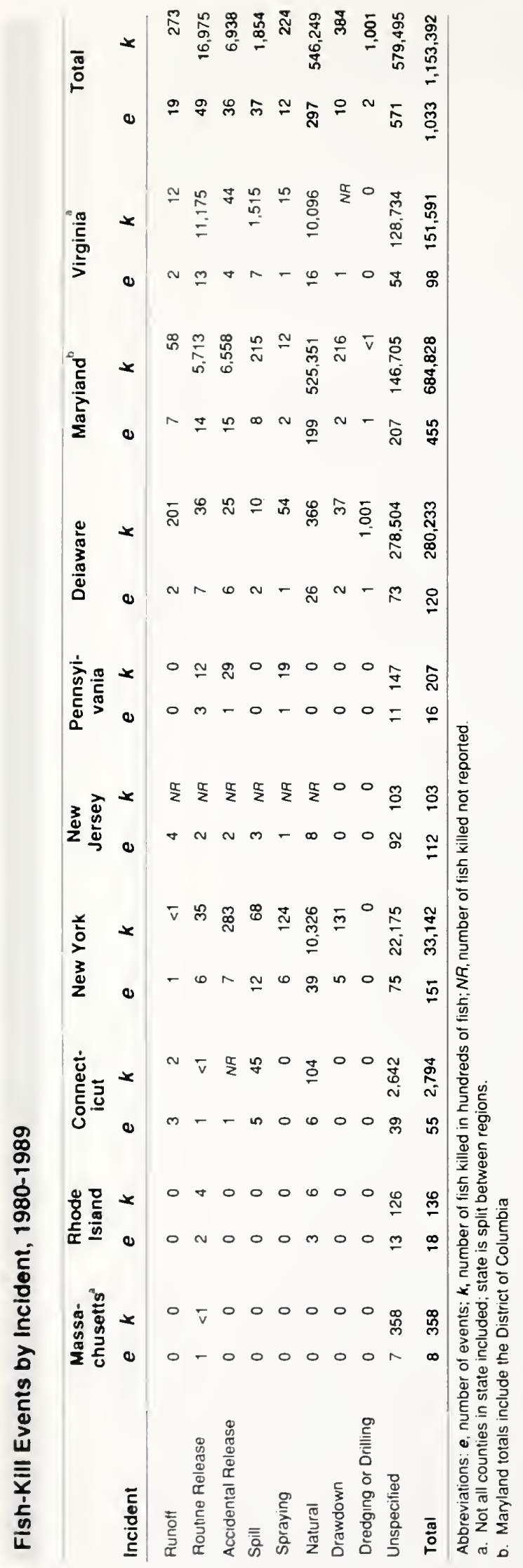





\section{Appendix A - South Atlantic}

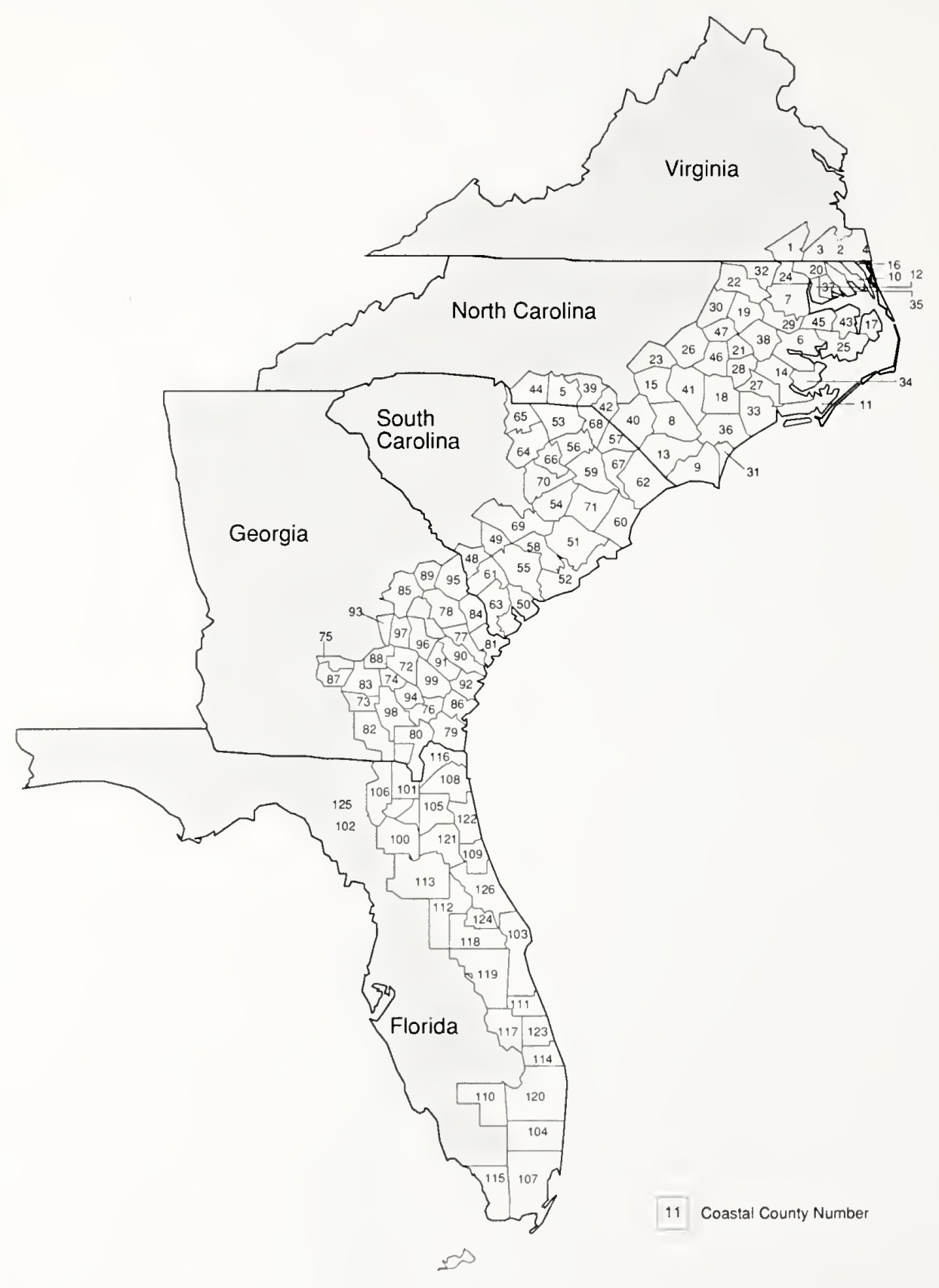


Fish-Kill Events by County, 1980-1989

\begin{tabular}{|c|c|c|c|c|c|}
\hline State/County & Events & $\begin{array}{l}\text { Killed } \\
(\times 100)\end{array}$ & $\begin{array}{l}\% \text { of events } \\
\text { where \# killed } \\
\text { was reported }\end{array}$ & $\begin{array}{l}\% \text { of events } \\
\text { where cause } \\
\text { of kill was reported }\end{array}$ & $\begin{array}{c}\text { \# of events } \\
\text { where } 1 \text { million or } \\
\text { more fish were killed }\end{array}$ \\
\hline \multicolumn{6}{|l|}{ Virgina } \\
\hline 1 Southampton & NO & ND & ND & $N D$ & ND \\
\hline 2 Chesapeake & 7 & 130 & 100 & 57 & 0 \\
\hline 3 Suffolk & ND & ND & $N D$ & ND & ND \\
\hline 4 Virginia Beach & 24 & 25,369 & 96 & 71 & 1 \\
\hline Subtotal & 31 & 25,499 & 97 & 68 & 1 \\
\hline \multicolumn{6}{|l|}{ North Carolina } \\
\hline 5 Anson & ND & ND & ND & ND & ND \\
\hline 6 Beaufort & 55 & 103,930 & 80 & 76 & 6 \\
\hline 7 Bertie & $N D$ & $N D$ & ND & ND & ND \\
\hline 8 Bladen & 1 & 2 & 100 & 100 & 0 \\
\hline 9 Brunswick & 1 & 2 & 100 & 0 & 0 \\
\hline 10 Camden & ND & NO & NO & ND & ND \\
\hline 11 Carteret & 5 & 38 & 60 & 20 & 0 \\
\hline 12 Chowan & 1 & 1 & 100 & 100 & 0 \\
\hline 13 Columbus & 4 & 8 & 100 & 100 & 0 \\
\hline 14 Craven & 15 & 1,216 & 60 & 80 & 0 \\
\hline 15 Cumberland & 2 & 40 & 100 & 100 & 0 \\
\hline 16 Currituck & ND & $N D$ & ND & ND & ND \\
\hline 17 Dare & 2 & 30,001 & 100 & 100 & 1 \\
\hline 18 Duplin & 4 & 3 & 75 & 50 & 0 \\
\hline 19 Edgecombe & 3 & 2 & 100 & 0 & 0 \\
\hline 20 Gates & ND & ND & ND & ND & ND \\
\hline 21 Greene & $N D$ & ND & NO & ND & ND \\
\hline 22 Halifax & 1 & 15 & 100 & 0 & 0 \\
\hline 23 Harnett & 2 & 1 & 50 & 100 & 0 \\
\hline 24 Hertford & $N D$ & $N D$ & $N D$ & ND & ND \\
\hline 25 Hyde & 6 & 60,058 & 100 & 50 & 2 \\
\hline 26 Johnston & ND & ND & $N D$ & ND & ND \\
\hline 27 Jones & 1 & $<1$ & 100 & 0 & 0 \\
\hline 28 Lenoir & 3 & 31 & 100 & 67 & 0 \\
\hline 29 Martin & 1 & 2 & 100 & 0 & 0 \\
\hline 30 Nash & $N D$ & ND & ND & ND & ND \\
\hline 31 New Hanover & 6 & 237 & 100 & 67 & 0 \\
\hline 32 Northampton & ND & $N D$ & ND & ND & ND \\
\hline 33 Onslow & 7 & 606 & 86 & 86 & 0 \\
\hline 34 Pamlico & 8 & 60,070 & 75 & 100 & 2 \\
\hline 35 Pasquotank & 4 & 23 & 100 & 25 & 0 \\
\hline 36 Pender & 1 & 10 & 100 & 100 & 0 \\
\hline 37 Perquimans & ND & ND & NO & ND & ND \\
\hline 38 Pitt & 3 & 22 & 100 & 100 & 0 \\
\hline 39 Richmond & ND & ND & $N D$ & ND & ND \\
\hline 40 Robeson & 3 & 4 & 100 & 67 & 0 \\
\hline 41 Sampson & 6 & 8 & 100 & 83 & 0 \\
\hline 42 Scotland & 1 & $<1$ & 100 & 0 & 0 \\
\hline 43 Tyrrell & 1 & $N R$ & 0 & 0 & 0 \\
\hline 44 Union & ND & ND & ND & NO & ND \\
\hline Wake & ND & ND & ND & ND & ND \\
\hline 45 Washington & 4 & 37 & 75 & 75 & 0 \\
\hline
\end{tabular}

Abbreviations: \%, percent; \#, number; NA, number of fish killed not reported; $N D$, no data was received. - Not shown on map. 
Fish-Kill Events by County, 1980-1989

\begin{tabular}{|c|c|c|c|c|c|}
\hline State County & Events & $\begin{array}{l}\text { Killed } \\
(x 100)\end{array}$ & $\begin{array}{l}\% \text { of events } \\
\text { where } \# \text { kilied } \\
\text { was reported }\end{array}$ & $\begin{array}{l}\% \text { of events } \\
\text { where cause } \\
\text { of kill was reported }\end{array}$ & $\begin{array}{l}\text { \# of events } \\
\text { where } 1 \text { miliiion or } \\
\text { more fish were killed }\end{array}$ \\
\hline \multicolumn{6}{|c|}{ North Carolina (cont.) } \\
\hline 46 Wayne & 1 & 30 & 0 & 100 & 0 \\
\hline 47 Wilson & 1 & $N R$ & 0 & 100 & 0 \\
\hline Subtotal & 153 & 256,397 & 82 & 71 & 11 \\
\hline \multicolumn{6}{|l|}{ South Carolina } \\
\hline 48 Allendale & ND & ND & ND & $N D$ & $N D$ \\
\hline 49 Bamberg & $N D$ & ND & $N D$ & $N D$ & ND \\
\hline 50 Beaufort & 73 & 343 & 96 & 70 & 0 \\
\hline 51 Berkeley & 11 & 72 & 91 & 64 & 0 \\
\hline 52 Charleston & 53 & 332 & 83 & 83 & 0 \\
\hline 53 Chesterfield & 2 & $<1$ & 50 & 0 & 0 \\
\hline 54 Clarendon & $N D$ & ND & $N D$ & $N D$ & $N D$ \\
\hline 55 Colleton & 5 & 165 & 80 & 100 & 0 \\
\hline 56 Darlington & 7 & 35 & 100 & 57 & 0 \\
\hline 57 Dillon & 1 & 2 & 100 & 100 & 0 \\
\hline 58 Dorchester & 9 & 24 & 89 & 67 & 0 \\
\hline 59 Florence & 8 & 192 & 88 & 88 & 0 \\
\hline 60 Georgetown & 1 & 100 & 100 & 100 & 0 \\
\hline 61 Hampton & 1 & 12 & 100 & 100 & 0 \\
\hline 62 Horry & 9 & 68 & 100 & 78 & 0 \\
\hline 63 Jasper & 2 & 21 & 100 & 50 & 0 \\
\hline 64 Kershaw & $N D$ & $N D$ & $N D$ & $N D$ & ND \\
\hline 65 Lancaster & ND & $N D$ & $N D$ & ND & $N D$ \\
\hline 66 Lee & $N D$ & ND & $N D$ & $N D$ & ND \\
\hline 67 Marion & 3 & 12 & 100 & 33 & 0 \\
\hline 68 Marlboro & 2 & 11 & 100 & 50 & 0 \\
\hline 69 Orangeburg & 1 & $<1$ & 100 & 0 & 0 \\
\hline 70 Sumter & 3 & 1 & 67 & 33 & 0 \\
\hline 71 Williamsburg & $N D$ & ND & $N D$ & ND & ND \\
\hline Subtotal & 191 & 1,393 & 91 & 72 & 0 \\
\hline \multicolumn{6}{|l|}{ Georgia } \\
\hline 72 Appling & ND & $N D$ & $N D$ & $N D$ & $N D$ \\
\hline 73 Atkinson & ND & ND & $N D$ & ND & $N D$ \\
\hline 74 Bacon & 2 & 14 & 100 & 0 & 0 \\
\hline 75 Ben Hill & $N D$ & $N D$ & $N D$ & $N D$ & ND \\
\hline 76 Brantley & 1 & 1 & 100 & 100 & 0 \\
\hline 77 Bryan & ND & $N D$ & $N D$ & $N D$ & $N D$ \\
\hline - Brooks & \multicolumn{5}{|c|}{ Data found in the Gull or Mexico Region. } \\
\hline 78 Bulloch & 1 & 1 & 100 & 100 & 0 \\
\hline 79 Camden & 2 & 16 & 100 & 0 & 0 \\
\hline 80 Charlton & ND & ND & $N D$ & ND & ND \\
\hline 81 Chatham & 15 & 26,949 & 100 & 0 & 1 \\
\hline 82 Clinch & ND & ND & ND & ND & ND \\
\hline 83 Coffee & 2 & 4 & 100 & 100 & 0 \\
\hline - Decatur & \multicolumn{5}{|c|}{ Data found in the Gull of Mexico Region. } \\
\hline 84 Efingham & ND & $N D$ & $N D$ & ND & ND \\
\hline
\end{tabular}

Abbrevations: \%, percent; * number; NR, number of "ish killed not reported; $N D$, no data was received.

- Not shown on map. 
Fish-Kill Events by County, 1980-1989

\begin{tabular}{|c|c|c|c|c|c|}
\hline State/County & Events & $\begin{array}{l}\text { Killed } \\
(\times 100)\end{array}$ & $\begin{array}{l}\% \text { of events } \\
\text { where \# killed } \\
\text { was reported }\end{array}$ & $\begin{array}{c}\% \text { of events } \\
\text { where cause } \\
\text { of kill was reported }\end{array}$ & $\begin{array}{c}\text { \# of events } \\
\text { where } 1 \text { million or } \\
\text { more fish were killed }\end{array}$ \\
\hline \multicolumn{6}{|l|}{ Georgia (cont.) } \\
\hline 85 Emanuel & ND & ND & ND & ND & ND \\
\hline - Evans & ND & ND & ND & ND & ND \\
\hline 86 Glynn & 3 & 82 & 100 & 0 & 0 \\
\hline * Grady & \multicolumn{5}{|c|}{ Data found in the Gulf of Mexico Region. } \\
\hline 87 Inwin & $N D$ & ND & ND & NO & ND \\
\hline 88 Jeff Davis & $N D$ & $N D$ & ND & ND & ND \\
\hline 89 Jenkins & ND & ND & ND & NO & ND \\
\hline 90 Liberty & $N D$ & ND & ND & ND & ND \\
\hline 91 Long & ND & ND & ND & ND & ND \\
\hline 92 Mclntosh & ND & ND & ND & ND & ND \\
\hline 93 Montgomery & ND & $N D$ & ND & ND & ND \\
\hline 94 Pierce & 1 & 43 & 100 & 0 & 0 \\
\hline 95 Screven & ND & ND & ND & ND & ND \\
\hline 96 Tattnall & ND & ND & ND & ND & ND \\
\hline * Thomas & \multicolumn{5}{|c|}{ Data found in the Gulf of Mexico Region. } \\
\hline 97 Toombs & ND & ND & ND & ND & ND \\
\hline 98 Ware & 5 & 7 & 100 & 100 & 0 \\
\hline 99 Wayne & 1 & 73 & 100 & 0 & 0 \\
\hline Subtotal & 33 & 27,192 & 100 & 100 & 1 \\
\hline \multicolumn{6}{|l|}{ Florida } \\
\hline 100 Alachua & 1 & $<1$ & 100 & 100 & 0 \\
\hline 101 Baker & 2 & 2 & 100 & 100 & 0 \\
\hline 102 Bradiord & ND & ND & ND & ND & ND \\
\hline 103 Brevard & 39 & 7,365 & 100 & 85 & 0 \\
\hline 104 Broward & 277 & 1,288 & 100 & 93 & 0 \\
\hline 105 Clay & 8 & 41 & 100 & 75 & 0 \\
\hline 106 Columbia & \multicolumn{5}{|c|}{ Data found in the Gulf of Mexico Region. } \\
\hline 107 Dade & 87 & 364 & 100 & 80 & 0 \\
\hline 108 Duval & 56 & 15,273 & 82 & 70 & 1 \\
\hline 109 Flagler & 1 & 30 & 100 & 100 & 0 \\
\hline 110 Hendry & \multicolumn{5}{|c|}{ Data found in the Gulf of Mexico Region. } \\
\hline 111 Indian River & 14 & 58 & 100 & 79 & 0 \\
\hline 112 Lake & 10 & 966 & 100 & 70 & 0 \\
\hline 113 Marion & 14 & 167,850 & 93 & 50 & 4 \\
\hline 114 Martin & 24 & 90 & 96 & 92 & 0 \\
\hline 115 Monroe & \multicolumn{5}{|c|}{ Data found in the Gulf of Mexico Region. } \\
\hline 116 Nassau & ND & ND & ND & ND & ND \\
\hline 117 Okeechobee & 9 & 200 & 100 & 100 & 0 \\
\hline 118 Orange & 18 & 360,234 & 89 & 72 & 2 \\
\hline 119 Osceola & ND & ND & ND & ND & ND \\
\hline 120 Palm Beach & 383 & 1,748 & 100 & 96 & 0 \\
\hline 121 Putnam & ND & ND & ND & ND & ND \\
\hline 122 St. Johns & 6 & 4,800 & 100 & 100 & 0 \\
\hline 123 St. Lucie & 61 & 290 & 100 & 90 & 0 \\
\hline 124 Seminole & 12 & 79,614 & 100 & 58 & 1 \\
\hline 125 Union & 2 & 1 & 50 & 100 & 0 \\
\hline 126 Volusia & 18 & 2,220 & 94 & 83 & 0 \\
\hline Subtotal & 1,042 & 642,432 & 98 & 89 & 8 \\
\hline Total & 1,450 & 952,913 & 96 & 84 & 21 \\
\hline National Total & 3,654 & $4,071,630$ & 84 & 79 & 86 \\
\hline
\end{tabular}

Abbreviations: \%, percent; \#, number; $N R$, number of fish killed not reported; $N D$, no data was received.

- Not shown on map. 
Fish-Kill Events by Year, 1980-1989

\begin{tabular}{|c|c|c|c|c|c|c|c|c|c|c|c|c|}
\hline \multirow[b]{2}{*}{ Year } & \multicolumn{2}{|c|}{ Virginia ${ }^{a}$} & \multicolumn{2}{|c|}{$\begin{array}{c}\text { North } \\
\text { Carolina }\end{array}$} & \multicolumn{2}{|c|}{$\begin{array}{c}\text { South } \\
\text { Carolina }\end{array}$} & \multicolumn{2}{|c|}{ Georgia } & \multicolumn{2}{|c|}{ Florida ${ }^{a}$} & \multicolumn{2}{|c|}{ Total } \\
\hline & $e$ & $k$ & $e$ & $k$ & $e$ & $k$ & $e$ & $k$ & $e$ & $k$ & $e$ & $k$ \\
\hline 1980 & 7 & 20,235 & 6 & 22 & 29 & 271 & 4 & 122 & 11 & 96 & 57 & 20,745 \\
\hline 1981 & 10 & 5,109 & 19 & 100,130 & 22 & 124 & 3 & 75 & 79 & 442,039 & 133 & 547,478 \\
\hline 1982 & 2 & 14 & 25 & 1,218 & 23 & 153 & 0 & 0 & 51 & 6,132 & 101 & 7,517 \\
\hline 1983 & 4 & 7 & 11 & 30,538 & 15 & 360 & 7 & 21 & 81 & 2,666 & 118 & 33,592 \\
\hline 1984 & 1 & 5 & 14 & 390 & 16 & 38 & 0 & 0 & 68 & 5,200 & 99 & 5,634 \\
\hline 1985 & 0 & 0 & 26 & 113,492 & 24 & 73 & 7 & 208 & 94 & 168,378 & 151 & 282,151 \\
\hline 1986 & 2 & 120 & 10 & 98 & 34 & 270 & 5 & 574 & 192 & 885 & 243 & 1,948 \\
\hline 1987 & 4 & 6 & 21 & 10,170 & 16 & 70 & 2 & 5 & 120 & 510 & 163 & 10,760 \\
\hline 1988 & 1 & 3 & 15 & 207 & 12 & 33 & 2 & 2 & 137 & 15,501 & 167 & 15,746 \\
\hline 1989 & 0 & 0 & 6 & 132 & 0 & 0 & 3 & 26,186 & 209 & 1,024 & 218 & 27,342 \\
\hline Total & 31 & 25,499 & 153 & 256,397 & 191 & 1,393 & 33 & 27,192 & 1,042 & 642,432 & 1,450 & 952,913 \\
\hline
\end{tabular}

Fish-Kill Events by Direct Cause, 1980-1989

\begin{tabular}{|c|c|c|c|c|c|c|c|c|c|c|c|c|}
\hline \multirow[b]{2}{*}{ Direct Cause } & \multicolumn{2}{|c|}{ Virginia ${ }^{a}$} & \multicolumn{2}{|c|}{$\begin{array}{c}\text { North } \\
\text { Carolina }\end{array}$} & \multicolumn{2}{|c|}{$\begin{array}{c}\text { South } \\
\text { Carolina }\end{array}$} & \multicolumn{2}{|c|}{ Georgia ${ }^{a}$} & \multicolumn{2}{|c|}{ Florida a } & \multicolumn{2}{|c|}{ Total } \\
\hline & $e$ & $k$ & $e$ & $k$ & $e$ & $k$ & $e$ & $k$ & $e$ & $k$ & $e$ & $k$ \\
\hline Low D. O. & 8 & 360 & 38 & 61,203 & 60 & 726 & 5 & 69 & 728 & 159,783 & 839 & 222,141 \\
\hline Temperature & 4 & 20,008 & 4 & 60,013 & 11 & 77 & 1 & 26,106 & 19 & 1,172 & 39 & 107,376 \\
\hline Sedimentation & 1 & $<1$ & 0 & 0 & 2 & 1 & 0 & 0 & 0 & 0 & 3 & 1 \\
\hline Eutrophication & 3 & 14 & 12 & 40,196 & 15 & 135 & 0 & 0 & 99 & 533 & 129 & 40,878 \\
\hline Disease & 0 & 0 & 8 & 131 & 0 & 0 & 0 & 0 & 0 & 0 & 8 & 131 \\
\hline Stranding & 1 & 1 & 2 & 10 & 2 & 25 & 3 & 12 & 7 & 2,543 & 15 & 2,591 \\
\hline Storm Event & 0 & 0 & 1 & 200 & 1 & 1 & 3 & 519 & 9 & 2,726 & 14 & 3,446 \\
\hline Wastewater & 0 & 0 & 3 & 5 & 8 & 26 & 6 & 163 & 17 & 13,718 & 34 & 13,912 \\
\hline Animal Waste & 1 & 12 & 4 & 42 & 0 & 0 & 2 & 45 & 1 & 10 & 8 & 109 \\
\hline $\mathrm{pH}$ & 0 & 0 & 0 & 0 & 0 & 0 & 0 & 0 & 1 & 2 & 1 & 2 \\
\hline Organic Chemicals & 0 & 0 & 0 & 0 & 1 & 10 & 2 & 81 & 1 & 200 & 4 & 291 \\
\hline Inorganic Chemicals/Metals & 0 & 0 & 2 & 3 & 0 & 0 & 0 & 0 & 1 & 6 & 3 & 9 \\
\hline Mixed Chemicals & 0 & 0 & 1 & 20 & 2 & 8 & 2 & 6 & 7 & 300,015 & 12 & 300,049 \\
\hline Pesticides & 0 & 0 & 9 & 47 & 29 & 216 & 0 & 0 & 18 & 15,224 & 56 & 15,488 \\
\hline Nutrient & 0 & 0 & 0 & 0 & 1 & 3 & 0 & 0 & 15 & 61,383 & 16 & 61,386 \\
\hline Salinity Changes & 2 & 5 & 22 & 94,286 & 3 & 31 & 0 & 0 & 4 & 81 & 31 & 94,403 \\
\hline Petroleum & 0 & 0 & 2 & $<1$ & 2 & 2 & 3 & 82 & 1 & $<1$ & 8 & 85 \\
\hline Chlorıne & 0 & 0 & 0 & 0 & 1 & $<1$ & 0 & 0 & 0 & 0 & 1 & $<1$ \\
\hline Red Tide & 1 & 3 & 0 & 0 & 0 & 0 & 0 & 0 & 1 & $<1$ & 2 & 3 \\
\hline Predation & 0 & 0 & 0 & 0 & 0 & 0 & 0 & 0 & 0 & 0 & 0 & 0 \\
\hline Unspecified & 10 & 5.096 & 45 & 241 & 53 & 133 & 6 & 109 & 113 & 85,037 & 227 & 90,615 \\
\hline Totai & 31 & 25,499 & 153 & 256,397 & 191 & 1,393 & 33 & 27,192 & 1,042 & 642,432 & 1,450 & 952,913 \\
\hline
\end{tabular}

Abbreviations e number of events; $\boldsymbol{k}$, number of fish killed in hundreds of fish; NR, number of fish killed not reported; Low D.O., low-dissolved oxygen.

a Nol all counties in state included, slate is split between regions. 
Fish-Kill Events by Land-Use Cause, 1980-1989

\begin{tabular}{|c|c|c|c|c|c|c|c|c|c|c|c|c|}
\hline \multirow[b]{2}{*}{ Land-Use Cause } & \multicolumn{2}{|c|}{ Virginia $^{a}$} & \multicolumn{2}{|c|}{$\begin{array}{c}\text { North } \\
\text { Carolina }\end{array}$} & \multicolumn{2}{|c|}{$\begin{array}{l}\text { South } \\
\text { Carolina }\end{array}$} & \multicolumn{2}{|c|}{ Georgia $^{a}$} & \multicolumn{2}{|c|}{ Florida $^{\text {a }}$} & \multicolumn{2}{|c|}{ Total } \\
\hline & $e$ & $k$ & $e$ & $k$ & $e$ & $k$ & $e$ & $k$ & $e$ & $k$ & $e$ & $k$ \\
\hline Agriculture & 2 & 32 & 10 & 83 & 2 & 20 & 5 & 122 & 26 & 11,787 & 45 & 12,044 \\
\hline Industrial & 0 & 0 & 4 & 5 & 2 & 171 & 2 & 81 & 19 & 15,051 & 27 & 15,308 \\
\hline Urban & 1 & $<1$ & 1 & 3 & 12 & 59 & 11 & 689 & 158 & 362,108 & 183 & 362,860 \\
\hline Impoundment & 4 & 20,014 & 21 & 30,666 & 3 & 25 & 1 & 1 & 15 & 2,563 & 44 & 53,269 \\
\hline Water-Related & 8 & 47 & 42 & 144,828 & 0 & 0 & 3 & 26,114 & 21 & 2,035 & 74 & 173,025 \\
\hline Silviculture & 0 & 0 & 1 & 20 & 0 & 0 & 0 & 0 & 0 & 0 & 1 & 20 \\
\hline Wildland & 0 & 0 & 0 & 0 & 0 & 0 & 0 & 0 & 0 & 0 & 0 & 0 \\
\hline Mining & 0 & 0 & 0 & 0 & 0 & 0 & 0 & 0 & 0 & 0 & 0 & 0 \\
\hline Military & 0 & 0 & 0 & 0 & 0 & 0 & 0 & 0 & 0 & 0 & 0 & 0 \\
\hline Unspecified & 16 & 5,406 & 74 & 80,792 & 172 & 1,117 & 11 & 185 & 803 & 248,887 & 1,076 & 336,387 \\
\hline Total & 31 & 25,499 & 153 & 256,397 & 191 & 1,393 & 33 & 27,192 & 1,042 & 642,432 & 1,450 & 952,913 \\
\hline
\end{tabular}

Fish-Kill Events by Incident, 1980-1989

\begin{tabular}{|c|c|c|c|c|c|c|c|c|c|c|c|c|}
\hline \multirow[b]{2}{*}{ Incident } & \multicolumn{2}{|c|}{ Virginia $^{a}$} & \multicolumn{2}{|c|}{$\begin{array}{c}\text { North } \\
\text { Carolina }\end{array}$} & \multicolumn{2}{|c|}{$\begin{array}{l}\text { South } \\
\text { Carolina }\end{array}$} & \multicolumn{2}{|c|}{ Georgia $^{a}$} & \multicolumn{2}{|c|}{ Florida $^{a}$} & \multicolumn{2}{|c|}{ Total } \\
\hline & e & k & e & k & e & k & e & k & e & k & e & $k$ \\
\hline Runoff & 1 & $<1$ & 6 & 55 & 3 & 23 & 3 & 519 & 151 & 375,989 & 164 & 376,586 \\
\hline Routine Release & 0 & 0 & 1 & 1 & 1 & 21 & 6 & 66 & 19 & 9,006 & 27 & 9,094 \\
\hline Accidental Release & 0 & 0 & 5 & 16 & 3 & 180 & 2 & 93 & 8 & 33 & 18 & 322 \\
\hline Spill & 0 & 0 & 4 & 3 & 7 & 7 & 2 & 82 & 3 & 8 & 16 & 100 \\
\hline Spraying & 0 & 0 & 2 & 2 & 3 & 28 & 0 & 0 & 3 & 51 & 8 & 81 \\
\hline Natural & 12 & 20,061 & 65 & 195,517 & 3 & 1 & 3 & 26,114 & 32 & 3,751 & 115 & 245,445 \\
\hline Drawdown & 0 & 0 & 1 & $<1$ & 2 & 25 & 1 & 3 & 3 & 2,540 & 7 & 2,569 \\
\hline Dredging or Drilling & 0 & 0 & 0 & 0 & 0 & 0 & 0 & 0 & 1 & $<1$ & 1 & $<1$ \\
\hline Unspecified & 18 & 5,438 & 69 & 60,802 & 169 & 1,107 & 16 & 314 & 822 & 251,054 & 1,094 & 318,715 \\
\hline Total & 31 & 25,499 & 153 & 256,397 & 191 & 1,393 & 33 & 27,192 & 1,042 & 642,432 & 1,450 & 952,913 \\
\hline
\end{tabular}

Abbreviations: $\boldsymbol{e}$ number of events; $\boldsymbol{k}$, number of fish killed in hundreds of fish; $N R$, number of fish killed not reported.

a. Not all counties in state included; state is split between regions. 


\section{Appendix A - Gulf of Mexico}

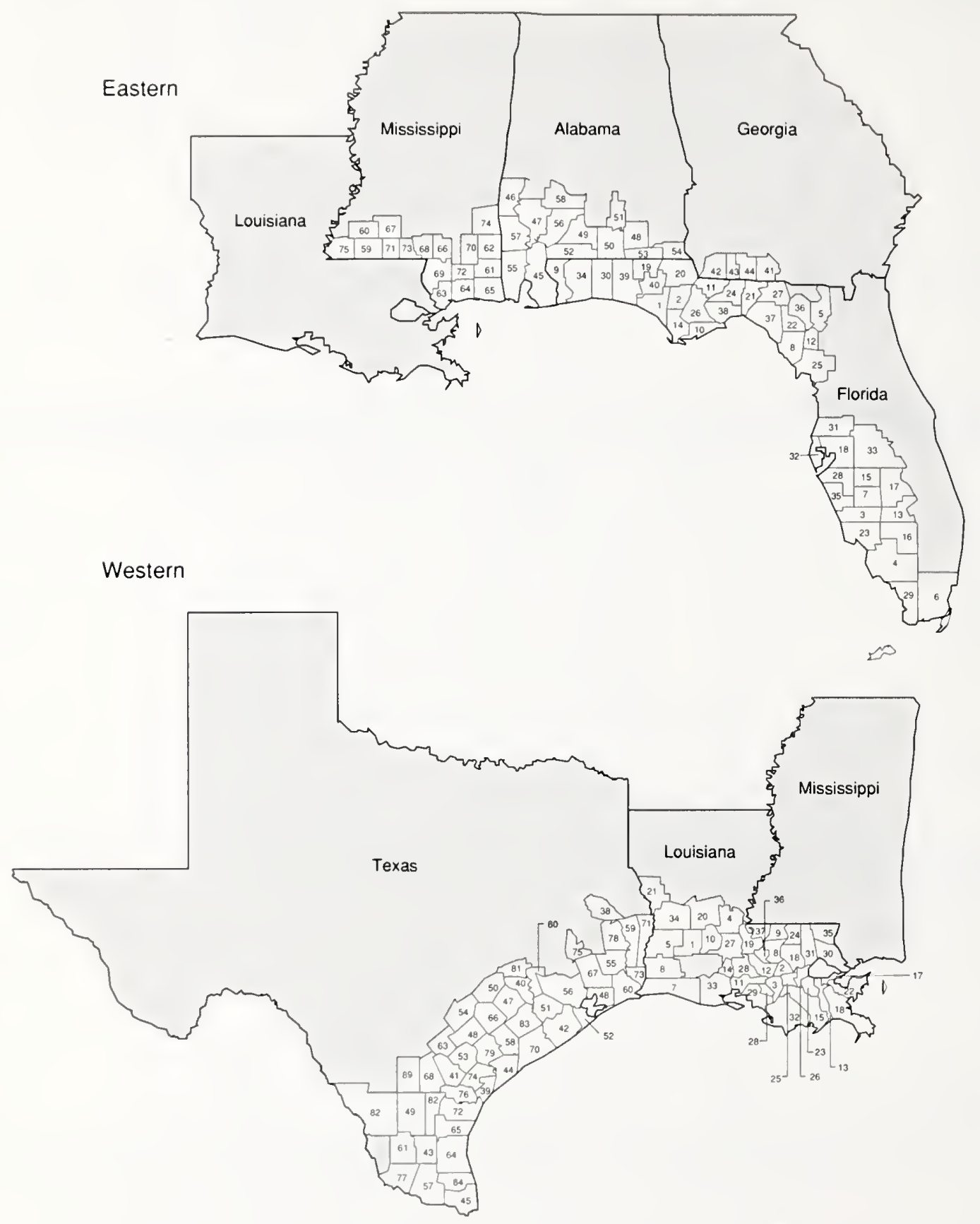

11. Coastal County Number 
Fish-Kill Events by County, 1980-1989

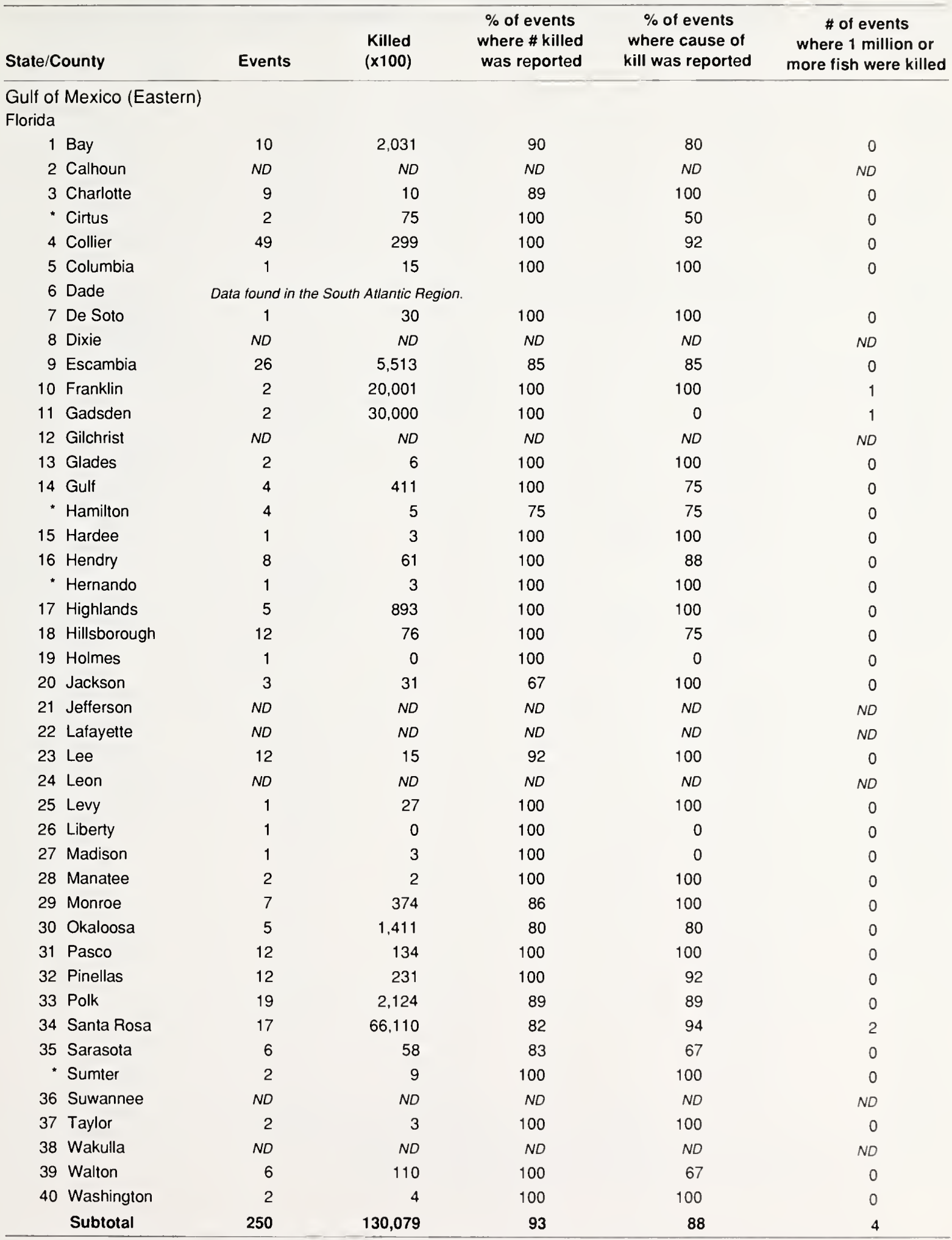

Abbreviations: \%, percent; \#, number; $N R$, number of fish killed not reported: $N D$, no data was received.

- Not shown on map. 


\section{Appendix A}

Fish-Kill Events by County, 1980-1989

\begin{tabular}{|c|c|c|c|c|c|}
\hline State County & Events & $\begin{array}{l}\text { Killed } \\
(\times 100)\end{array}$ & $\begin{array}{c}\% \text { of events } \\
\text { where \# killed } \\
\text { was reported }\end{array}$ & $\begin{array}{l}\% \text { of events } \\
\text { where cause of } \\
\text { kill was reported }\end{array}$ & $\begin{array}{c}\text { \# of events } \\
\text { where } 1 \text { million or } \\
\text { more fish were killed }\end{array}$ \\
\hline \multicolumn{6}{|c|}{ Gulf of Mexico (Eastern) } \\
\hline \multicolumn{6}{|l|}{ Georgia } \\
\hline 41 Brooks & ND & $N D$ & ND & ND & ND \\
\hline 42 Decatur & ND & ND & ND & ND & ND \\
\hline 43 Grady & ND & ND & ND & ND & ND \\
\hline 44 Thomas & 2 & 14 & 100 & 50 & 0 \\
\hline Subtotal & 2 & 14 & 100 & 50 & 0 \\
\hline \multicolumn{6}{|l|}{ Alabama } \\
\hline 45 Baldwin & 12 & 91,429 & 83 & 100 & 2 \\
\hline 46 Choctaw & ND & ND & ND & ND & ND \\
\hline 47 Clarke & ND & ND & ND & ND & ND \\
\hline 48 Coffee & ND & ND & ND & ND & ND \\
\hline 49 Conecuh & ND & ND & ND & ND & ND \\
\hline 50 Covington & 1 & 0 & 100 & 100 & 0 \\
\hline 51 Crenshaw & ND & ND & ND & ND & ND \\
\hline 52 Escambia & ND & ND & ND & ND & ND \\
\hline 53 Geneva & ND & ND & ND & ND & ND \\
\hline 54 Houston & ND & ND & ND & ND & ND \\
\hline 55 Mobile & 30 & 40,537 & 93 & 87 & 2 \\
\hline 56 Monroe & ND & ND & ND & ND & ND \\
\hline 57 Washington & 1 & 1 & 100 & 100 & 0 \\
\hline 58 Wilcox & ND & ND & ND & ND & ND \\
\hline Subtotal & 44 & 131,967 & 91 & 91 & 4 \\
\hline \multicolumn{6}{|l|}{ Mississippi } \\
\hline 59 Amite & ND & ND & ND & ND & ND \\
\hline 60 Franklin & $N D$ & NO & ND & ND & ND \\
\hline 61 George & ND & ND & ND & ND & ND \\
\hline 62 Greene & ND & ND & ND & ND & ND \\
\hline 63 Hancock & 2 & 55 & 100 & 100 & 0 \\
\hline 64 Harrison & 2 & 4 & 50 & 100 & 0 \\
\hline 65 Jackson & 2 & 20,002 & 100 & 50 & 1 \\
\hline 66 Lamar & ND & ND & ND & ND & ND \\
\hline 67 Lincoln & ND & ND & ND & ND & ND \\
\hline 68 Marion & 1 & 20 & 100 & 100 & 0 \\
\hline 69 Pearl River & ND & ND & ND & ND & ND \\
\hline 70 Perry & ND & ND & ND & ND & ND \\
\hline 71 Pike & NO & $N D$ & $N D$ & ND & ND \\
\hline 72 Stone & ND & ND & ND & ND & ND \\
\hline 73 Walthall & $N D$ & ND & $N D$ & ND & ND \\
\hline 74 Wayne & ND & ND & ND & ND & ND \\
\hline 75 Wilkınson & ND & ND & ND & ND & ND \\
\hline Subtotal & 7 & 20,081 & 86 & 86 & 1 \\
\hline
\end{tabular}

Abbreviations $\%$. percent, \#, number; NR, number of fish killed not reported, ND, no data was received. 
Fish-Kill Events by County, 1980-1989

\begin{tabular}{|c|c|c|c|c|c|}
\hline State/County & Events & $\begin{array}{l}\text { Killed } \\
(x 100)\end{array}$ & $\begin{array}{l}\% \text { of events } \\
\text { where \# killed } \\
\text { was reported }\end{array}$ & $\begin{array}{l}\% \text { of events } \\
\text { where cause of } \\
\text { kill was reported }\end{array}$ & $\begin{array}{c}\text { \# of events } \\
\text { where } 1 \text { million or } \\
\text { more fish were killed }\end{array}$ \\
\hline
\end{tabular}

Gulf of Mexico (Western)

Louisiana

1 Allen

2 Ascension

3 Assumption

4 Avoyelles

5 Beauregard

6 Calcasieu

7 Cameron

8 East Baton Rouge

9 East Feliciana

10 Evangeline

11 Iberia

12 Iberville

13 Jefferson

* Jefferson Davis

14 Lafayette

15 Lafourche

16 Livingston

17 Orleans

18 Plaquemines

19 Point Coupee

20 Rapides

21 Sabine

22 St. Bernard

23 St. Charles

24 St. Helena

25 St. James

26 St. John the Baptist

5

ND

5

9

ND

ND

5

3

17

ND

ND

8

14

7

2

4

13

1

9

5

ND

ND

ND

6

7

ND

5

27 St. Landry

28 St. Martin

29 St. Mary

30 St. Tammany

31 Tangipahoa

32 Terrebonne

33 Vermilion

34 Vernon

35 Washington

36 West Baton Rouge

37 West Feliciana Subtotal

172

96

961
ND

12

547

ND

ND

33

3

144

ND

ND

73

222

13

NA

970

56

6

14

873

ND

$N D$

ND

4

115

ND

24

NR

4

NR

778

109

7

1,144

10

ND

ND

9

460

6,590
80

ND

80

89

ND

ND

60

33

82

ND

ND

38

79

43

0

50

54

100

44

80

ND

ND

ND

33

29

ND

80

0

100

0

75

69

67

43

50

ND

ND

100

50
80

ND

80

89

ND

ND

80

100

71

ND

$N D$

100

71

71

100

75

100

100

78

100

ND

ND

ND

83

86

ND

100

100

100

100

100

85

83

93

50

ND

ND

67

100

85
0

ND

0

0

ND

ND

0

0

0

ND

ND

0

0

0

0

0

0

0

0

0

ND

ND

ND

0

0

ND

0

0
0

0

0
0

0
0

0
0

0
0

ND

ND

0

0

61

0

Abbreviations: \%, percent; \#, number; $N R$, number of fish killed not reported;ND, no data was received. " Not shown on map. 
Fish-Kill Events by County, 1980-1989

\begin{tabular}{llll}
\hline & Killed & $\begin{array}{c}\% \text { of events } \\
\text { where \# klled } \\
\text { was reported }\end{array}$ & $\begin{array}{c}\% \text { of events } \\
\text { where cause of } \\
\text { klll was reported }\end{array} \quad \begin{array}{c}\# \text { of events } \\
\text { where } 1 \text { million or }\end{array}$ \\
\hline
\end{tabular}

\section{Gulf of Mexico (Western)}

Texas

38 Angelina

39 Aransas

40 Austin

41 Bee

42 Brazoria

43 Brooks

44 Calhoun

45 Cameron

46 Chambers

47 Colorado

48 De Witt

49 Duval

50 Fayette

51 Fort Bend

52 Galveston

53 Goliad

54 Gonzales

55 Hardin

56 Harris

57 Hidalgo

58 Jackson

59 Jasper

60 Jefferson

$61 \mathrm{Jim}$ Hogg

$62 \mathrm{Jim}$ Wells

63 Karnes

64 Kenedy

65 Kleberg

66 Lavaca

67 Liberty

68 Live Oak

69 McMullen

70 Matagorda

71 Newton

72 Nueces

73 Orange

74 Refugio

75 San Jacinto

76 San Patricio

77 Starr

78 Tyler

79 Victoria

80 Waller

81 Washington

82 Webb

83 Wharton

84 Willacy

Subtotal
ND

10

2

ND

36

ND

11

8

20

ND

ND

ND

ND

19

72

ND

ND

1

66

1

1

3

20

ND

1

ND

1

4

3

6

ND

ND

24

4

15

14

3

ND

5

1

ND

1

ND

ND

ND

3

ND

355

$\begin{array}{rr}N D & N D \\ 6,297 & 30 \\ 5 & 100 \\ N D & N D \\ 15,569 & \\ N D & \\ 225 & \\ 13,785 & \end{array}$

ND

30

100

ND

69

ND

45

63

90

ND

ND

ND

ND

68

81

ND

ND

0

59

100

100

100

75

ND

0

ND

100

25

67

33

ND

ND

54

0

60

79

67

ND

60

100

ND

0

ND

ND

ND

0

0
ND

70

100

ND

81

ND

82

88

90

ND

ND

ND

ND

58

90

ND

ND

0

80

100

100

100

80

ND

0

ND

0

100

67

83

ND

ND

88

75

80

79

67

ND

100

100

ND

0

ND

ND

ND

100

ND

D
ND

0

ND

1

ND

0

1

5

ND

$N D$

ND

ND

0

8

ND

ND

0

3

0

0

0

0

ND

0

ND

0

0

0

0

ND

ND

0

0

2

0

0

ND

1

0

ND

0

ND

ND

ND

0

ND

21

$\begin{array}{lrrr}\text { Total } & 830 & 1,881,610 & 75 \\ \text { National Total } & 3,654 & 4,071,630 & 84\end{array}$

Abbreviations \%, percent: *, number; NR, number of fish killed not reported; ND, no data was received. 
Fish-Kill Events by Year, 1980-1989

\begin{tabular}{|c|c|c|c|c|c|c|c|c|c|c|c|c|c|c|}
\hline \multirow[b]{2}{*}{ Year } & \multicolumn{2}{|c|}{ Florida $^{a}$} & \multicolumn{2}{|c|}{ Georgia $^{a}$} & \multicolumn{2}{|c|}{ Alabama } & \multicolumn{2}{|c|}{ Mississippi } & \multicolumn{2}{|c|}{ Louisiana } & \multicolumn{2}{|c|}{ Texas } & \multicolumn{2}{|c|}{ Total } \\
\hline & $e$ & $k$ & $e$ & $k$ & $e$ & $k$ & $e$ & $k$ & $e$ & $k$ & $e$ & $k$ & $e$ & $k$ \\
\hline 1980 & 25 & 56 & 0 & 0 & 7 & 194 & 0 & 0 & 2 & 158 & 58 & $1,095,440$ & 92 & $1,095,848$ \\
\hline 1981 & 32 & 59,704 & 0 & 0 & 1 & 0 & 1 & 2 & 10 & 76 & 52 & 56,061 & 96 & 115,843 \\
\hline 1982 & 24 & 3,662 & 0 & 0 & 2 & 10 & 0 & 0 & 5 & 4 & 66 & 78,534 & 97 & 82,209 \\
\hline 1983 & 24 & 30,782 & 1 & 3 & 3 & 1 & 0 & 0 & 17 & 220 & 52 & 74,994 & 97 & 106,000 \\
\hline 1984 & 26 & 22,911 & 0 & 0 & 12 & 118,753 & 0 & 0 & 22 & 412 & 22 & 235,828 & 82 & 377,904 \\
\hline 1985 & 26 & 1,350 & 0 & 0 & 3 & 3 & 1 & 20 & 22 & 978 & 0 & 0 & 52 & 2,352 \\
\hline 1986 & 30 & 10,938 & 0 & 0 & 3 & 70 & 2 & 55 & 38 & 3,323 & 9 & 1 & 82 & 14,387 \\
\hline 1987 & 16 & 115 & 0 & 0 & 10 & 12,934 & 1 & 4 & 16 & 487 & 15 & 6 & 58 & 13,546 \\
\hline 1988 & 21 & 317 & 0 & 0 & 2 & 2 & 1 & 0 & 17 & 115 & 53 & 48,687 & 94 & 49,121 \\
\hline 1989 & 26 & 243 & 1 & 11 & 1 & 2 & 1 & 20,000 & 23 & 817 & 28 & 3,328 & 80 & 24,401 \\
\hline Total & 250 & 130,079 & 2 & 14 & 44 & 131,967 & 7 & 20,081 & 172 & 6,590 & 355 & $1,592,880$ & 830 & $1,881,610$ \\
\hline
\end{tabular}

Fish-Kill Events by Direct Cause, 1980-1989

\begin{tabular}{|c|c|c|c|c|c|c|c|c|c|c|c|c|c|c|}
\hline \multirow[b]{2}{*}{ Direct Cause } & \multicolumn{2}{|c|}{ Florida $^{a}$} & \multicolumn{2}{|c|}{ Georgia $^{a}$} & \multicolumn{2}{|c|}{ Alabama } & \multicolumn{2}{|c|}{ Mississippi } & \multicolumn{2}{|c|}{ Louisiana } & \multicolumn{2}{|c|}{ Texas } & \multicolumn{2}{|c|}{ Total } \\
\hline & $e$ & $k$ & $e$ & $k$ & $e$ & $k$ & $e$ & $k$ & $e$ & $k$ & $e$ & $k$ & $e$ & $k$ \\
\hline Low D. O. & 116 & 29,947 & 0 & 0 & 23 & 131,901 & 0 & 0 & 63 & 1,577 & 119 & $1,173,795$ & 321 & $1,337,220$ \\
\hline Temperature & 17 & 421 & 0 & 0 & 0 & 0 & 1 & 20,000 & 5 & 753 & 18 & 39,617 & 41 & 60,791 \\
\hline Sedimentation & 0 & 0 & 0 & 0 & 0 & 0 & 0 & 0 & 6 & 359 & 5 & 20 & 11 & 379 \\
\hline Eutrophication & 15 & 51,206 & 0 & 0 & 1 & 2 & 0 & 0 & 4 & 5 & 6 & 13,015 & 26 & 64,228 \\
\hline Disease & 4 & 19 & 0 & 0 & 1 & $<1$ & 0 & 0 & 2 & $<1$ & 8 & 20 & 15 & 39 \\
\hline Stranding & 6 & 134 & 0 & 0 & 0 & 0 & 0 & 0 & 5 & 3 & 5 & 5,169 & 16 & 5,306 \\
\hline Storm Event & 7 & 164 & 0 & 0 & 0 & 0 & 1 & 20 & 17 & 1,009 & 23 & 43,375 & 48 & 44,569 \\
\hline Wastewater & 11 & 1,255 & 1 & 3 & 10 & 44 & 0 & 0 & 21 & 1,058 & 29 & 224,624 & 72 & 226,984 \\
\hline Animal Waste & 3 & 815 & 0 & 0 & 0 & 0 & 0 & 0 & 3 & 7 & 1 & 1,000 & 7 & 1,822 \\
\hline $\mathrm{pH}$ & 0 & 0 & 0 & 0 & 0 & 0 & 0 & 0 & 2 & 3 & 2 & $<1$ & 4 & 3 \\
\hline Organic Chemicals & 2 & 2 & 0 & 0 & 1 & 4 & 0 & 0 & 3 & 88 & 1 & NR & 7 & 94 \\
\hline Inorganic Chemicals/Metals & 4 & 84 & 0 & 0 & 1 & $N R$ & 0 & 0 & 3 & 577 & 18 & 51,713 & 26 & 52,375 \\
\hline Mixed Chemicals & 10 & 11,647 & 0 & 0 & 3 & 12 & 0 & 0 & 5 & 4 & 6 & 6,598 & 24 & 18,261 \\
\hline Pesticides & 10 & 379 & 0 & 0 & 0 & 0 & 1 & $N A$ & 2 & NR & 13 & 3,765 & 26 & 4,143 \\
\hline Nutrients & 12 & 1,557 & 0 & 0 & 0 & 0 & 0 & 0 & 2 & 5 & 5 & 404 & 19 & 1,966 \\
\hline Salinity Changes & 0 & 0 & 0 & 0 & 0 & 0 & 3 & 59 & 1 & NR & 2 & 13 & 6 & 72 \\
\hline Petroleum & 1 & 50 & 0 & 0 & 0 & 0 & 0 & 0 & 2 & NR & 20 & 28,594 & 23 & 28,644 \\
\hline Chlorine & 0 & 0 & 0 & 0 & 0 & 0 & 0 & 0 & 0 & 0 & 2 & 75 & 2 & 75 \\
\hline Red Tide & 1 & 1,909 & 0 & 0 & 0 & 0 & 0 & 0 & 0 & 0 & 8 & $<1$ & 9 & 1,909 \\
\hline Predation & 0 & 0 & 0 & 0 & 0 & 0 & 0 & 0 & 0 & 0 & 0 & 0 & 0 & 0 \\
\hline Unspecified & 31 & 30,489 & 1 & 11 & 4 & 3 & 1 & 2 & 26 & 1,142 & 64 & 1,083 & 127 & 32,730 \\
\hline Total & 250 & 130,079 & 2 & 14 & 44 & 131,967 & 7 & 20,081 & 172 & 6,590 & 355 & $1,592,880$ & 830 & $1,881,610$ \\
\hline
\end{tabular}

Abbreviations: $a$ number of events; $\boldsymbol{k}$, number of fish killed in hundreds of fish; NR, number of fish killed not reported; Low D.O., low-dissolved oxygen.

a. Not all counties in state included; state is split between regions. 
Appendix A

Fish-Kill Events by Land-Use Cause, 1980-1989

\begin{tabular}{|c|c|c|c|c|c|c|c|c|c|c|c|c|c|c|}
\hline \multirow[b]{2}{*}{ Land-Use Cause } & \multicolumn{2}{|c|}{ Florida ${ }^{\circ}$} & \multicolumn{2}{|c|}{ Georgia } & \multicolumn{2}{|c|}{ Alabama } & \multicolumn{2}{|c|}{ Mississippi } & \multicolumn{2}{|c|}{ Louisiana } & \multicolumn{2}{|c|}{ Texas } & \multicolumn{2}{|c|}{ Total } \\
\hline & $e$ & $k$ & $e$ & $k$ & $e$ & $k$ & $e$ & $k$ & $e$ & $k$ & $e$ & $k$ & $e$ & $k$ \\
\hline Agriculture & 6 & 95 & 0 & 0 & 0 & 0 & 0 & 0 & 7 & 43 & 11 & 4,893 & 24 & 5,031 \\
\hline Industrial & 12 & 61,000 & 1 & 11 & 1 & 10 & 0 & 0 & 29 & 2,179 & 54 & 12,332 & 97 & 75,532 \\
\hline Urban & 56 & 3,153 & 1 & 3 & 10 & 42 & 0 & 0 & 21 & 85 & 58 & 273,098 & 146 & 276,381 \\
\hline Impoundment & 16 & 1,457 & 0 & 0 & 4 & 134 & 0 & 0 & 36 & 1,073 & 13 & 31,260 & 69 & 33,923 \\
\hline Water-Related & 18 & 2,215 & 0 & 0 & 1 & 68 & 5 & 20,079 & 14 & 927 & 67 & 594,179 & 105 & 617,468 \\
\hline Silviculture & 0 & 0 & 0 & 0 & 0 & 0 & 0 & 0 & 0 & 0 & 0 & 0 & 0 & 0 \\
\hline Wildland & 0 & 0 & 0 & 0 & 0 & 0 & 0 & 0 & 0 & 0 & 0 & 0 & 0 & 0 \\
\hline Mining & 1 & 4 & 0 & 0 & 0 & 0 & 0 & 0 & 1 & NR & 5 & 2 & 7 & 6 \\
\hline Molitary & 0 & 0 & 0 & 0 & 0 & 0 & 0 & 0 & 0 & 0 & 0 & 0 & 0 & 0 \\
\hline Unspecified & 141 & 62,154 & 0 & 0 & 28 & 131,713 & 2 & 2 & 64 & 2,283 & 147 & 677,116 & 382 & 873,268 \\
\hline Total & 250 & 130,079 & 2 & 14 & 44 & 131,967 & 7 & 20,081 & 172 & 6,590 & 355 & $1,592,880$ & 830 & $1,881,610$ \\
\hline
\end{tabular}

Fish-Kill Events by Incident, 1980-1989

\begin{tabular}{|c|c|c|c|c|c|c|c|c|c|c|c|c|c|c|}
\hline \multirow[b]{2}{*}{ Incident } & \multicolumn{2}{|c|}{ Florida $^{a}$} & \multicolumn{2}{|c|}{ Georgia $^{a}$} & \multicolumn{2}{|c|}{ Alabama } & \multicolumn{2}{|c|}{ Mississippi } & \multicolumn{2}{|c|}{ Louisiana } & \multicolumn{2}{|c|}{ Texas } & \multicolumn{2}{|c|}{ Total } \\
\hline & $e$ & $k$ & $e$ & $k$ & $e$ & $k$ & $e$ & $k$ & $e$ & $k$ & $e$ & $k$ & $e$ & $k$ \\
\hline Runoff & 48 & 279 & 0 & 0 & 1 & NR & 0 & 0 & 8 & 57 & 23 & 21,348 & 80 & 21,685 \\
\hline Routine Release & 6 & 10,056 & 0 & 0 & 3 & 11 & 0 & 0 & 23 & 1,945 & 26 & 798 & 58 & 12,809 \\
\hline Accidental Release & 6 & 207 & 1 & 3 & 3 & 24 & 0 & 0 & 16 & 138 & 23 & 3,660 & 49 & 4,032 \\
\hline Spill & 7 & 1,826 & 0 & 0 & 0 & 0 & 1 & $N R$ & 2 & 460 & 32 & 1,835 & 42 & 4,121 \\
\hline Spraying & 5 & $118^{-}$ & 0 & 0 & 0 & 0 & 0 & 0 & 1 & $N R$ & 4 & 3,760 & 10 & 3,878 \\
\hline Nătural & 26 & 2,570 & 0 & 0 & 6 & 204 & 5 & 20,079 & 43 & 1,251 & 71 & 615,259 & 151 & 639,364 \\
\hline Drawdown & 1 & 1 & 0 & 0 & 0 & 0 & 0 & 0 & 4 & 6 & 2 & 190 & 7 & 197 \\
\hline Dredging or Drilling & 1 & 1,000 & 0 & 0 & 0 & 0 & 0 & 0 & 6 & 358 & 10 & 10 & 17 & 1,368 \\
\hline Unspecified & 150 & 114,022 & 1 & 11 & 31 & 131,729 & 1 & 2 & 69 & 2,376 & 164 & 946,018 & 416 & $1,194,158$ \\
\hline Total & 250 & 130,079 & 2 & 14 & 44 & 131,967 & 7 & 20,081 & 172 & 6,590 & 355 & $1,592,880$ & 830 & $1,881,610$ \\
\hline
\end{tabular}

Abbreviations: e number of events: $\boldsymbol{k}$, number of fish killed in hundreds of fish; NR, number of fish killed not reported

a Not all counties in state included; state is split between regions. 

Appendix A - Pacific

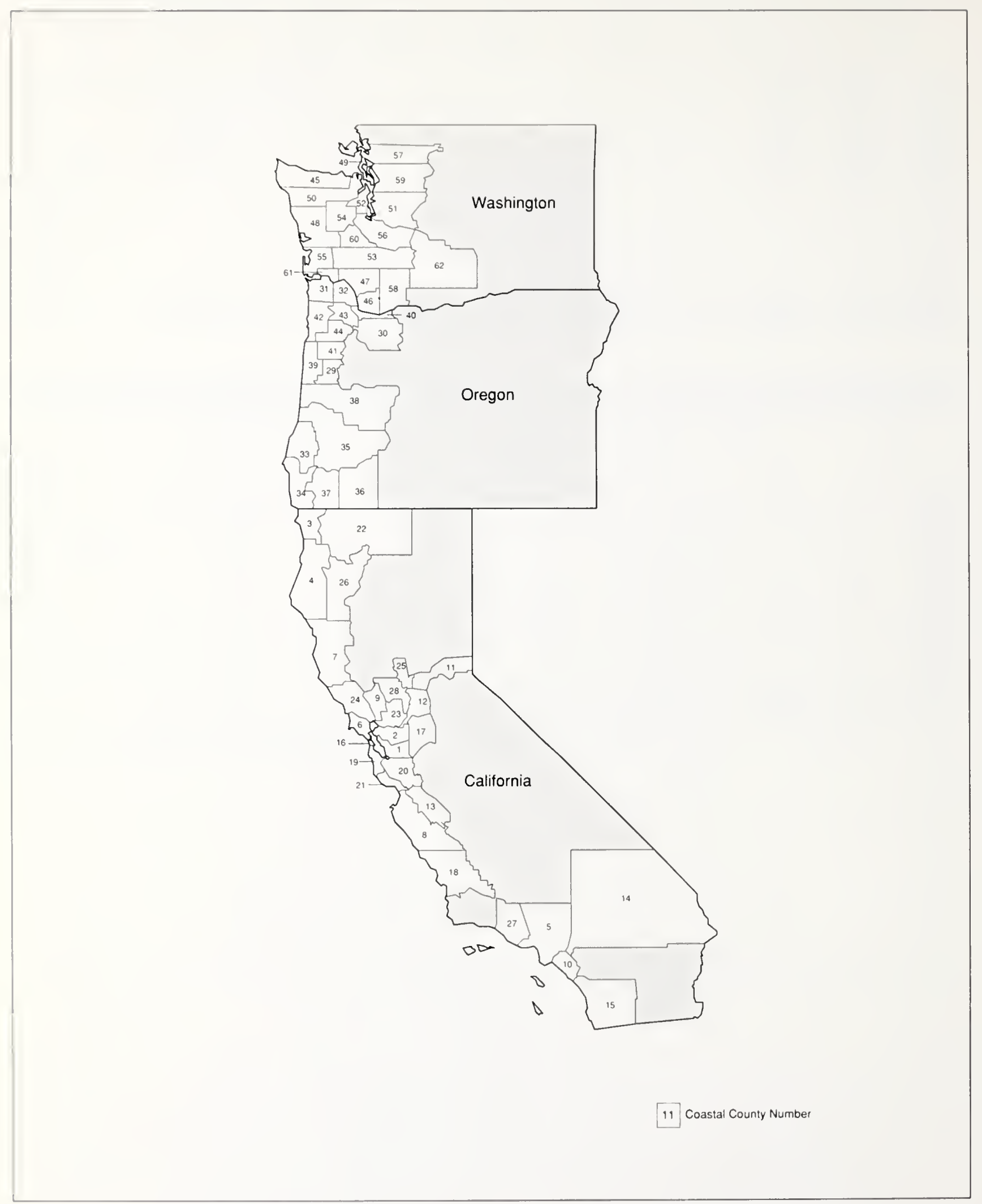


Fish-Kill Events by County, 1980-1989

\begin{tabular}{|c|c|c|c|c|c|c|}
\hline State/Co & ounty & Events & $\begin{array}{l}\text { Killed } \\
(x 100)\end{array}$ & $\begin{array}{l}\% \text { of events } \\
\text { where \# killed } \\
\text { was reported }\end{array}$ & $\begin{array}{c}\% \text { of events } \\
\text { where cause of } \\
\text { kill was reported }\end{array}$ & $\begin{array}{l}\text { \# of events } \\
\text { where } 1 \text { million or } \\
\text { more fish were killed }\end{array}$ \\
\hline \multicolumn{7}{|c|}{ California } \\
\hline 1 & Alameda & 6 & 516 & 100 & 83 & 0 \\
\hline 2 & Contra Costa & 6 & 65 & 100 & 67 & 0 \\
\hline 3 & Del Norte & $N D$ & ND & ND & ND & ND \\
\hline 4 & Humboldt & 1 & $<1$ & 100 & 100 & 0 \\
\hline 5 & Los Angeles & 12 & 5,739 & 100 & 83 & 0 \\
\hline 6 & Marin & 11 & 25 & 100 & 82 & 0 \\
\hline 7 & Mendocino & 2 & 1 & 100 & 100 & 0 \\
\hline 8 & Monterey & 9 & 200 & 100 & 56 & 0 \\
\hline 9 & Napa & 1 & 1 & 100 & 100 & 0 \\
\hline 10 & Orange & 5 & 66 & 80 & 60 & 0 \\
\hline 11 & Placer & ND & ND & ND & ND & ND \\
\hline 12 & Sacramento & 7 & 28 & 86 & 43 & 0 \\
\hline 13 & San Benito & ND & ND & ND & ND & ND \\
\hline 14 & San Bernardino & ND & $N D$ & ND & ND & ND \\
\hline 15 & San Diego & 2 & 14 & 100 & 100 & 0 \\
\hline 16 & San Francisco & 1 & 500 & 100 & 100 & 0 \\
\hline 17 & San Joaquin & 27 & 396 & 100 & 78 & 0 \\
\hline 18 & San Luis Obispo & 13 & 160 & 100 & 85 & 0 \\
\hline 19 & San Mateo & 17 & 280 & 94 & 65 & 0 \\
\hline * & Santa Barbara & 5 & 363 & 80 & 60 & 0 \\
\hline 20 & Santa Clara & 6 & 15 & 100 & 83 & 0 \\
\hline 21 & Santa Cruz & 5 & 525 & 100 & 80 & 0 \\
\hline 22 & Siskiyou & 1 & 101 & 100 & 100 & 0 \\
\hline 23 & Solano & 3 & 3 & 100 & 0 & 0 \\
\hline 24 & Sonoma & 5 & 107 & 100 & 100 & 0 \\
\hline 25 & Sutter & 1 & 1 & 100 & 100 & 0 \\
\hline 26 & Trinity & ND & ND & ND & ND & ND \\
\hline 27 & Ventura & ND & ND & $N D$ & ND & ND \\
\hline \multirow[t]{2}{*}{28} & Yolo & 2 & 162 & 100 & 100 & 0 \\
\hline & Subtotal & 148 & 9,267 & 97 & 74 & 0 \\
\hline \multicolumn{7}{|l|}{ Oregon } \\
\hline 29 & Benton & ND & ND & ND & ND & ND \\
\hline 30 & Clackamas & 6 & 165 & 67 & 67 & 0 \\
\hline 31 & Clatsop & ND & ND & ND & ND & ND \\
\hline 32 & Columbia & 8 & 13 & 75 & 88 & 0 \\
\hline 33 & Coos & 2 & 45 & 50 & 100 & 0 \\
\hline 34 & Curry & 1 & 5 & 100 & 0 & 0 \\
\hline 35 & Douglas & 3 & 283 & 100 & 67 & 0 \\
\hline 36 & Jackson & ND & $N D$ & $N D$ & ND & ND \\
\hline 37 & Josephine & 1 & 123 & 100 & 100 & 0 \\
\hline 38 & Lane & 5 & 37 & 100 & 60 & 0 \\
\hline 39 & Lincoln & 4 & 16 & 100 & 100 & 0 \\
\hline 40 & Multnomah & 9 & 186 & 89 & 56 & 0 \\
\hline 41 & Polk & ND & ND & ND & $N D$ & ND \\
\hline 42 & Tillamook & 1 & 2 & 100 & 100 & 0 \\
\hline 43 & Washington & ND & ND & ND & ND & ND \\
\hline \multirow[t]{2}{*}{44} & Yamhill & ND & $N D$ & ND & ND & ND \\
\hline & Subtotal & 40 & 874 & 90 & 73 & 0 \\
\hline
\end{tabular}

Abbreviations: $N R$, number of fish killed not reported; $N D$, no data was received. "Not shown on map. 
Appendix A

Fish-Kill Events by County, 1980-1989

\begin{tabular}{|c|c|c|c|c|c|}
\hline State County & Events & $\begin{array}{l}\text { Killed } \\
(\times 100)\end{array}$ & $\begin{array}{l}\% \text { of events } \\
\text { where \# killed } \\
\text { was reported }\end{array}$ & $\begin{array}{c}\% \text { of events } \\
\text { where cause of } \\
\text { kill was reported }\end{array}$ & $\begin{array}{l}\text { \# of events } \\
\text { where } 1 \text { million or } \\
\text { more fish were killed }\end{array}$ \\
\hline \multicolumn{6}{|l|}{ Washington } \\
\hline 45 Clallam & 3 & 4 & 100 & 67 & 0 \\
\hline 46 Clark & 4 & 16 & 50 & 75 & 0 \\
\hline 47 Cowlitz & 2 & NR & 0 & 100 & 0 \\
\hline 48 Grays Harbor & 2 & 525 & 100 & 100 & 0 \\
\hline 49 Island & 2 & 25,700 & 50 & 100 & 1 \\
\hline 50 Jefferson & ND & ND & ND & ND & ND \\
\hline 51 King & 39 & 1,037 & 79 & 56 & 0 \\
\hline 52 Kitsap & 1 & 2 & 100 & 0 & 0 \\
\hline 53 Lewis & 1 & 99 & 100 & 100 & 0 \\
\hline 54 Mason & 2 & 3 & 100 & 0 & 0 \\
\hline 55 Pacific & ND & ND & ND & ND & ND \\
\hline 56 Pierce & 9 & 212 & 89 & 100 & 0 \\
\hline 57 Skagit & 3 & 20 & 33 & 100 & 0 \\
\hline 58 Skamania & ND & ND & ND & ND & ND \\
\hline 59 Snohomish & 16 & 859 & 75 & 81 & 0 \\
\hline 60 Thurston & 5 & 3,554 & 80 & 100 & 0 \\
\hline 61 Wahkiakum & ND & ND & ND & ND & ND \\
\hline - Whatcom & 16 & 640 & 75 & 75 & 0 \\
\hline \multirow{2}{*}{$\begin{array}{l}62 \text { Yakima } \\
\text { Subtotal }\end{array}$} & ND & ND & ND & ND & ND \\
\hline & 105 & 32,670 & 76 & 72 & 1 \\
\hline Total & 293 & 42,811 & 88 & 73 & 1 \\
\hline National Total & 3,654 & $4,071,630$ & 84 & 79 & 86 \\
\hline
\end{tabular}

Abbreviations: NR, number of tish killed not reported; ND, no data was received. 
Fish-Kill Events by Year, 1980-1989

\begin{tabular}{|c|c|c|c|c|c|c|c|c|}
\hline \multirow[b]{2}{*}{ Year } & \multicolumn{2}{|c|}{ California } & \multicolumn{2}{|c|}{ Oregon } & \multicolumn{2}{|c|}{ Washington } & \multicolumn{2}{|c|}{ Total } \\
\hline & $e$ & $k$ & $e$ & $k$ & $e$ & $k$ & $e$ & $k$ \\
\hline 1980 & 23 & 713 & 13 & 195 & 7 & 519 & 43 & 1,427 \\
\hline 1981 & 31 & 522 & 8 & 102 & 10 & 29,856 & 49 & 30,480 \\
\hline 1982 & 24 & 6,258 & 5 & 59 & 8 & 129 & 37 & 6,445 \\
\hline 1983 & 13 & 105 & 0 & 0 & 6 & 424 & 19 & 529 \\
\hline 1984 & 12 & 315 & 7 & 2 & 9 & 178 & 28 & 496 \\
\hline 1985 & 19 & 506 & 2 & 124 & 6 & 372 & 27 & 1,002 \\
\hline 1986 & 5 & 13 & 5 & 392 & 12 & 462 & 22 & 867 \\
\hline 1987 & 10 & 711 & 0 & 0 & 28 & 706 & 38 & 1,417 \\
\hline 1988 & 9 & 124 & 0 & 0 & 9 & 13 & 18 & 136 \\
\hline 1989 & 2 & $<1$ & 0 & 0 & 10 & 12 & 12 & 12 \\
\hline Total & 148 & 9,267 & 40 & 874 & 105 & 32,670 & 293 & 42,811 \\
\hline
\end{tabular}

Fish-Kill Events by Direct Cause, 1980-1989

\begin{tabular}{|c|c|c|c|c|c|c|c|c|}
\hline \multirow[b]{2}{*}{ Direct Cause } & \multicolumn{2}{|c|}{ California } & \multicolumn{2}{|c|}{ Oregon } & \multicolumn{2}{|c|}{ Washington } & \multicolumn{2}{|c|}{ Total } \\
\hline & $e$ & $k$ & $e$ & $k$ & $e$ & $k$ & $e$ & $k$ \\
\hline Low D. O. & 25 & 949 & 1 & $N R$ & 7 & 25,986 & 33 & 26,935 \\
\hline Temperature & 6 & 80 & 2 & 2 & 0 & 0 & 8 & 82 \\
\hline Sedimentation & 1 & 150 & 0 & 0 & 0 & 0 & 1 & 150 \\
\hline Eutrophication & 1 & $<1$ & 1 & 2 & 1 & 1 & 3 & 3 \\
\hline Disease & 5 & 90 & 0 & 0 & 2 & $<1$ & 7 & 90 \\
\hline Stranding & 6 & 439 & 3 & 400 & 3 & 262 & 12 & 1,101 \\
\hline Storm Event & 1 & 51 & 0 & 0 & 0 & 0 & 1 & 51 \\
\hline Wastewater & 8 & 676 & 0 & 0 & 6 & 952 & 14 & 1,628 \\
\hline Animal Waste & 5 & 50 & 0 & 0 & 21 & 853 & 26 & 903 \\
\hline $\mathrm{pH}$ & 0 & 0 & 0 & 0 & 3 & 30 & 3 & 30 \\
\hline Organic Chemicals & 5 & 84 & 3 & 19 & 1 & 1 & 9 & 103 \\
\hline Inorganic Chemicals/Metals & 7 & 313 & 6 & 195 & 3 & 3.160 & 16 & 3,668 \\
\hline Mixed Chemicals & 4 & 108 & 4 & 176 & 5 & 104 & 13 & 388 \\
\hline Pesticides & 17 & 279 & 3 & 7 & 7 & 555 & 27 & 841 \\
\hline Nutrients & 1 & 5 & 0 & 0 & 0 & 0 & 1 & 5 \\
\hline Salinity Changes & 2 & 149 & 0 & 0 & 0 & 0 & 2 & 149 \\
\hline Petroleum & 5 & 47 & 3 & $<1$ & 7 & 98 & 15 & 145 \\
\hline Chlorine & 11 & 5,247 & 3 & 48 & 10 & 458 & 24 & 5,753 \\
\hline Red Tide & 0 & 0 & 0 & 0 & 0 & 0 & 0 & 0 \\
\hline Predation & 0 & 0 & 0 & 0 & 0 & 0 & 0 & 0 \\
\hline Unspecified & 38 & 550 & 11 & 26 & 29 & 210 & 78 & 786 \\
\hline Total & 148 & 9,267 & 40 & 874 & 105 & 32,670 & 293 & 42,811 \\
\hline
\end{tabular}

Abbreviations: $e$ number of events; $\boldsymbol{k}$, number of fish killed in hundreds of fish; NR. number of fish killed not reported: Low D.O. low-dissolved oxygen. 
Fish-Kill Events by Land-Use Cause, 1980-1989

\begin{tabular}{lrrrrrrrr} 
& \multicolumn{2}{c}{ California } & \multicolumn{2}{c}{ Oregon } & \multicolumn{2}{c}{ Washington } & \multicolumn{2}{c}{ Total } \\
Land-Use Cause & $\boldsymbol{e}$ & \multicolumn{1}{c}{$\boldsymbol{k}$} & \multicolumn{1}{c}{$\boldsymbol{e}$} & \multicolumn{1}{c}{$\boldsymbol{k}$} & $\boldsymbol{c}$ & $\boldsymbol{k}$ & $\boldsymbol{c}$ & $\boldsymbol{k}$ \\
\hline Agriculture & 10 & 226 & 5 & 52 & 26 & 1,026 & $\mathbf{4 1}$ & $\mathbf{1 , 3 0 4}$ \\
Industrial & 5 & 5,058 & 13 & 719 & 8 & 567 & $\mathbf{2 6}$ & 6,344 \\
Urban & 10 & 972 & 2 & 13 & 19 & 1,344 & $\mathbf{3 1}$ & $\mathbf{2 , 3 2 9}$ \\
Impoundment & 13 & 510 & 3 & 5 & 8 & 3,688 & $\mathbf{2 4}$ & $\mathbf{4 , 2 0 3}$ \\
Water-Related & 5 & 69 & 1 & 10 & 8 & 25,723 & $\mathbf{1 4}$ & $\mathbf{2 5 , 8 0 1}$ \\
Silviculture & 1 & 101 & 0 & 0 & 0 & 0 & $\mathbf{1}$ & $\mathbf{1 0 1}$ \\
Wildland & 0 & 0 & 0 & 0 & 0 & 0 & 0 & 0 \\
Mining & 0 & 0 & 0 & 0 & 0 & 0 & 0 & 0 \\
Military & 0 & 0 & 0 & 0 & 0 & 0 & $\mathbf{0}$ & $\mathbf{0}$ \\
Unspecified & 104 & 2,332 & 16 & 75 & 36 & 323 & $\mathbf{1 5 6}$ & $\mathbf{2 , 7 3 0}$ \\
Total & $\mathbf{1 4 8}$ & $\mathbf{9 , 2 6 7}$ & $\mathbf{4 0}$ & $\mathbf{8 7 4}$ & $\mathbf{1 0 5}$ & $\mathbf{3 2 , 6 7 0}$ & $\mathbf{2 9 3}$ & $\mathbf{4 2 , 8 1 1}$
\end{tabular}

Fish-Kill Events by Incident, 1980-1989

\begin{tabular}{lrrrrrrrr} 
& \multicolumn{2}{c}{ California } & \multicolumn{2}{c}{ Oregon } & \multicolumn{2}{c}{ Washington } & \multicolumn{2}{c}{ Total } \\
Incident & $\boldsymbol{e}$ & \multicolumn{1}{c}{$\boldsymbol{k}$} & $\boldsymbol{e}$ & $\boldsymbol{k}$ & $\boldsymbol{e}$ & $\boldsymbol{k}$ & $\boldsymbol{c}$ & $\boldsymbol{k}$ \\
\hline Runoff & 3 & 33 & 0 & 0 & 4 & 487 & $\mathbf{7}$ & $\mathbf{5 1 9}$ \\
Routine Release & 4 & 5,600 & 5 & 51 & 17 & 1,182 & $\mathbf{2 6}$ & 6,834 \\
Accidental Release & 3 & 76 & 3 & 12 & 7 & 128 & $\mathbf{1 3}$ & $\mathbf{2 1 7}$ \\
Spill & 10 & 97 & 8 & 17 & 10 & 729 & $\mathbf{2 8}$ & $\mathbf{8 4 3}$ \\
Spraying & 1 & 101 & 0 & 0 & 6 & 206 & $\mathbf{7}$ & $\mathbf{3 0 6}$ \\
Natural & 12 & 134 & 3 & 12 & 9 & 28,844 & $\mathbf{2 4}$ & $\mathbf{2 8 , 9 9 0}$ \\
Drawdown & 3 & 432 & 1 & 110 & 3 & 545 & $\mathbf{7}$ & $\mathbf{1 , 0 8 6}$ \\
Dredging or Drilling & 2 & 158 & 0 & 0 & 0 & 0 & $\mathbf{2}$ & $\mathbf{1 5 8}$ \\
Unspecified & 110 & 2,637 & 20 & 671 & 49 & 551 & $\mathbf{1 7 9}$ & $\mathbf{3 , 8 5 9}$ \\
Total & $\mathbf{1 4 8}$ & $\mathbf{9 , 2 6 7}$ & $\mathbf{4 0}$ & $\mathbf{8 7 4}$ & $\mathbf{1 0 5}$ & $\mathbf{3 2 , 6 7 0}$ & $\mathbf{2 9 3}$ & $\mathbf{4 2 , 8 1 1}$ \\
\hline
\end{tabular}

Abbreviations: $\boldsymbol{e}$ number of events; $\boldsymbol{k}$, number of fish killed in hundreds of fish; $N R$, number of fish killed not reported. 


\section{Appendix B}

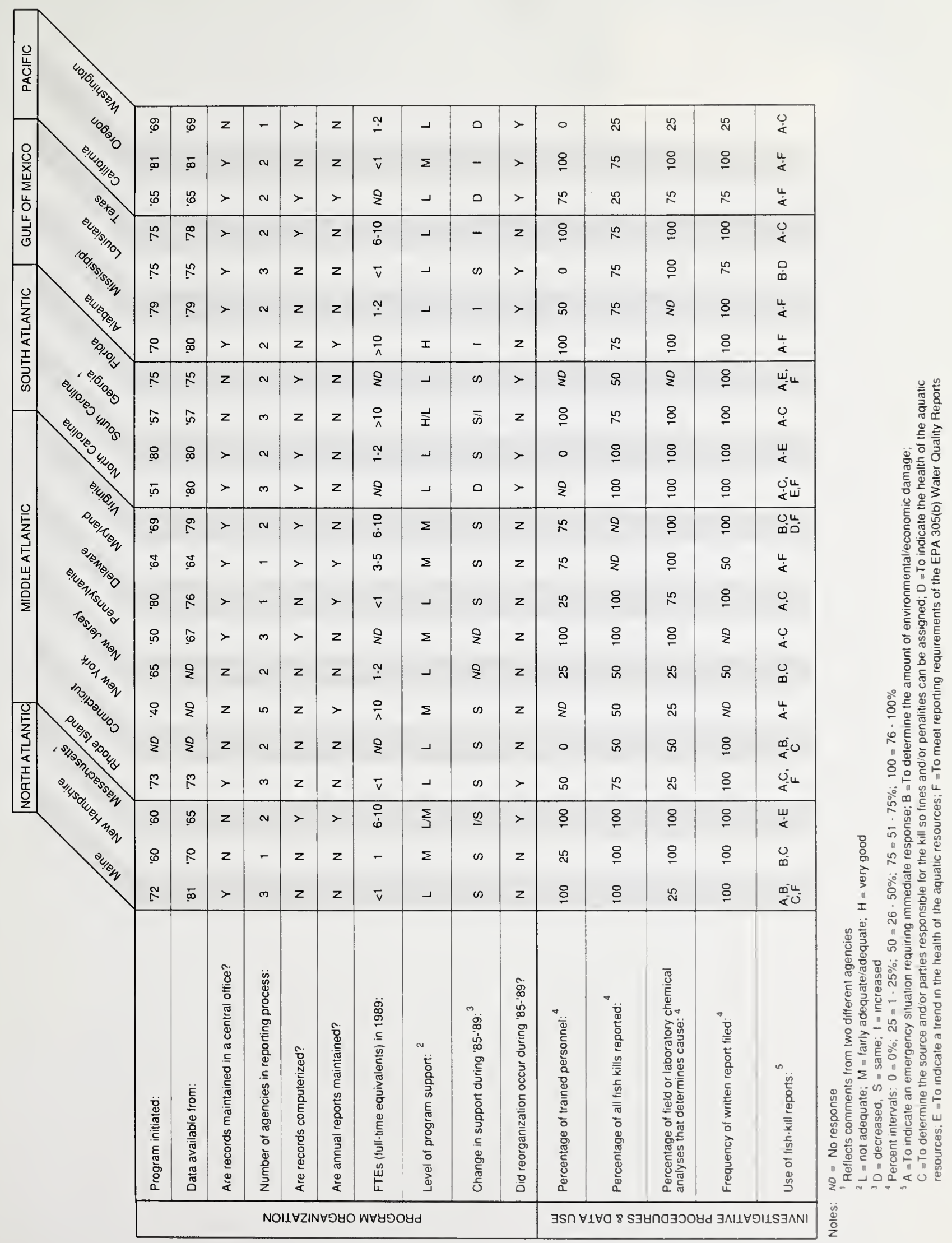


||||||||||||||||||||||||

ADO00 28278029 



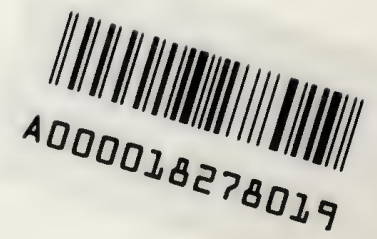

